\title{
Etnologia Indígena no contexto de Estados nacionais diversos: Brasil, Austrália, Canadá
}

Indigenous ethnology in the context of diverse national states: Brazil, Australia, Canada

\section{Stephen G. Baines}

\section{(2) OpenEdition}

Edição electrónica

URL: http://journals.openedition.org/aa/3094

DOI: 10.4000/aa.3094

ISSN: 2357-738X

\section{Editora}

Programa de Pós-Graduação em Antropologia Social (UnB)

Edição impressa

Data de publição: 1 julho 2018

Paginação: 365-454

ISSN: 0102-4302

\section{Refêrencia eletrónica}

Stephen G. Baines, «Etnologia Indígena no contexto de Estados nacionais diversos: Brasil, Austrália, Canadá», Anuário Antropológico [Online], v.43 n.1 | 2018, posto online no dia 26 maio 2019, consultado o 27 abril 2021. URL: http://journals.openedition.org/aa/3094 ; DOI: https://doi.org/10.4000/aa.3094

\section{cc) (†)}

Anuário Antropológico is licensed under a Creative Commons Atribuição-Uso Não-Comercial-Proibição de realização de Obras Derivadas 4.0 International. 


\title{
Etnologia Indígena no contexto de Estados nacionais diversos: Brasil, Austrália, Canadá
}

\author{
Stephen G. Baines
}

UnB

Este memorial foi apresentado ao Departamento de Antropologia (DAN) da Universidade de Brasília (UnB), em setembro de 2015, como parte dos requisitos para a ascensão à classe de professor titular ${ }^{1}$. Apresento uma versão revisada, mantendo o conteúdo principal do original, que visa apresentar uma perspectiva retrospectiva sobre a minha trajetória acadêmica. Ao longo do memorial, incluí as minhas publicações que pretendia destacar da totalidade no meu Currículo Lattes. Organizei o Memorial, narrando a trajetória da minha formação, que se iniciou na Inglaterra em níveis de Graduação e de Mestrado, com a decisão de realizar o doutorado em Antropologia na Universidade de Brasília (UnB), quando preparei um projeto de pesquisa para estudar o povo indígena Waimiri-Atroari, a partir dos estudos em etnologia indígena e do contato interétnico. Relato como, mais tarde, iniciei uma pesquisa sobre nacionalidade e etnicidade em uma fronteira internacional junto aos povos Makuxi e Wapichana na fronteira Brasil-Guiana e, desde 2008, realizo uma pesquisa sobre a criminalização indígena no sistema penitenciário de Boa Vista, Roraima. Depois, abordo algumas noções centrais que orientam minhas pesquisas e relato como iniciei uma pesquisa sobre os estilos de etnologia indígena que se praticam na Austrália e no Canadá, a partir da etnologia indígena que se faz no Brasil.

Iniciei meus estudos de graduação em Belas Artes no Barnet College of Arts, no norte de Londres, Inglaterra (1965-66), cidade em que nasci e fui criado, e no South Hertfordshire College of Art, na cidade de St. Albans (1966-67). Apesar de ter sido aceito para seguir um curso de quatro anos de duração de "Diploma em Artes Gráficas” na Liverpool School of Art, resolvi mudar de área e fazer os exames para entrar em curso de Línguas Semíticas na University of Leeds, onde ingressei em 1968. No primeiro ano, iniciei um novo curso de graduação (BA Hons. Combined Arts) em Língua/Literatura Árabe e Estudos Comparativos da Religião, onde, além de estudar a língua e a literatura árabe, tive acesso a obras 
clássicas da Sociologia da Religião como as de Émile Durkheim, Marcel Mauss, Max Weber, Karl Marx e outros. Apresentei dissertação de graduação intitulada, "Práticas e Ideias Sufi no Mundo Islâmico".

Após concluir a graduação em 1971, recebi oferta de uma bolsa para realizar a pós-graduação em árabe no Departamento de Línguas Semíticas da Universidade de Leeds, mas resolvi que o estudo da língua árabe não era minha vocação, e que queria mesmo conhecer culturas diferentes. Parti para conhecer um pouco do mundo antes de fazer uma pós-graduação. Durante a graduação, nas férias de verão, viajava pelo Oriente Médio, Norte da África, e Sul da Ásia, e em outubro de 1971, parti pela Europa e Turquia para o Irã, onde planejava dar aulas de inglês e estudar a língua persa (farsi). Após uma estadia de seis meses no Irã (de outubro de 1971 a abril de 1972), lecionando em inglês e estudando a língua persa, num período político muito conturbado dos últimos anos do governo de Muhammad Reza Shah Pahlevi, e sem conseguir o visto para trabalhar e estudar naquele país, viajei extensivamente pelo Afeganistão, Paquistão, Índia e Bangladesh, voltando pelo Oriente Médio e Europa, à Inglaterra, em 1973. Passei alguns meses lecionando inglês em escolas de idiomas em Londres, e trabalhando como professor temporário em colégios de ensino de Segundo Grau no norte de Londres. Parti para as Américas com o interesse de obter conhecimento sobre as populações indígenas.

Após atravessar os Estados Unidos e visitar comunidades indígenas em alguns estados, passei três meses no México e América Central, e segui para Colômbia, Equador, Peru (onde lecionei inglês em Lima), Bolívia, Paraguai, Argentina, Chile, e Uruguai, chegando ao Brasil em abril de 1975. Em dezembro de 1974, em posto policial situado na estrada transchaco no Paraguai, ouvi, no rádio, notícia da morte do sertanista Gilberto Pinto Figueiredo Costa e de outros funcionários da Fundação Nacional do Índio (FUNAI) no Posto Indígena Abonari, na Frente de Atração Waimiri-Atroari (FAWA).

Em muitos destes países, visitei comunidades indígenas e me candidatei a realizar trabalhos voluntários, entretanto sem encontrar possibilidades de obter o visto. Após atravessar o sul do Brasil, encontrei-me com o sertanista Apoena Meirelles, na sede da Fundação Nacional do Índio (FUNAI) em Cuiabá, na época em que havia participado da transferência do povo indígena Panará do Igarapé Peixoto de Azevedo ao Parque do Xingu, quando seu território foi atingido pela rodovia Cuiabá-Santarém. 
Segui por Rondônia, Acre e Amazonas e, em junho de 1975, cheguei aos limites das terras do povo indígena Waimiri-Atroari, no momento em que seu território estava sendo cortado pela rodovia BR-174. Do $\mathrm{km} 45$ ao norte da Ponte de Bolívia na saída de Manaus, o então comandante do $6^{\circ}$ Batalhão de Engenharia de Construção ( $\left.6^{\circ} \mathrm{BEC}\right)$ aceitou me levar até o Igarapé Santo Antônio do Abonari, nos limites da terra indígena, na condição de que voltasse no dia seguinte. Dormi no quartel de Abonari e conversei com os soldados sobre seus contatos com os Waimiri-Atroari e, no dia seguinte, o comandante providenciou transporte do Exército para me levar os $6 \mathrm{~km}$ até a ponte sobre o Igarapé Santo Antônio do Abonari, nos limites da área interditada para a chamada “pacificação dos Waimiri-Atroari”. Ali conversei por rádio com o então sertanista da FUNAI, Apoena Meirelles, que havia sido transferido de Mato Grosso para a Frente de Atração Waimiri-Atroari (FAWA), após a morte do sertanista Gilberto Pinto Figueiredo Costa, em dezembro de 1974, em ataque ao posto indígena Abonari. Voltei ao acampamento do $6^{\circ} \mathrm{BEC}$ em Abonari, onde o comandante reiterou a ordem que eu teria de voltar a Manaus em viatura do Exército. Logo chegou uma frota de ônibus ao quartel do $6^{\circ} \mathrm{BEC}$ e fui colocado em um ônibus junto com soldados do mesmo Batalhão que me informaram que, após a morte do sertanista Gilberto Pinto Figueiredo Costa e de vários servidores da FUNAI no Posto Indígena Abonari, em dezembro de 1974, as obras na construção da rodovia BR-174 haviam sido suspensas. Informaram-me que estavam sendo enviados a Manaus por três semanas enquanto o $1^{\circ}$ Batalhão de Infantaria da Selva $\left(1^{\circ} \mathrm{BIS}\right)$ ocupasse a trajetória da rodovia BR-174 para realizar demonstrações de força com morteiros e metralhadoras, para mostrar para os Waimiri-Atroari que não havia mais como resistir à construção da rodovia. Em sentido contrário, vindo de Manaus, presenciei os caminhões do $1^{\circ}$ BIS trazendo soldados e artilharia.

Em Manaus, conheci o então antropólogo do DAN/UnB, professor Peter Silverwood-Cope, que na época estava trabalhando em projeto de saúde indígena em Iauaretê no Alto Rio Negro. Ele me informou que se fizesse curso de atendente de enfermagem para ter uma qualificação brasileira em área aproveitável pela FUNAI, poderia solicitar minha contratação pela FUNAI, e me apresentou ao então Delegado Regional da FUNAI em Manaus, Francisco Mont'alverne Pires, que me informou que precisaria ter o visto permanente no Brasil para poder ser contratado pela FUNAI. Passei dois anos em Manaus, onde completei 
o curso de atendente de enfermagem na Unidade Sanitária Morro da Liberdade, e lecionei inglês em escola de línguas e para pesquisadores do Instituto Nacional de Pesquisas na Amazônia (INPA), dando aulas particulares.

Entreguei três pedidos sucessivos à Policia Federal para obter o visto permanente no Brasil junto com promessas de emprego. Entretanto, todos foram indeferidos. Neste período, atravessei novamente o território dos Waimiri-Atroari e tive contatos breves com os indígenas na rodovia, em 1976, no Posto Indígena Terraplenagem.

Em 1977, sem obter o visto permanente no Brasil, segui para a Venezuela, onde tentei trabalhar junto a povos indígenas. No Ministério de Sanidad, em Caracas, Sr. Alejandro Paez, que trabalhava no Setor de Saúde Indígena, se manifestou muito favorável ao meu trabalho, considerando que havia vários postos de saúde no território Yanomami sem atendentes, e propôs que eu trabalhasse em Platanal no alto rio Orenoco como encarregado da região, por ter a Graduação completa. Após três meses de espera, em que viajei ao território do povo indígena Panare, meu pedido para visto de trabalho foi negado pelo Departamento Indigenista em que o diretor, coronel, insistiu que estrangeiros não poderiam trabalhar em área de fronteira.

Segui para os Estados Unidos, México, Nova Zelândia e Austrália, países em que fui aceito para ingressar em programas de mestrado em antropologia na University of Texas em Austin, Estados Unidos, na Universidad Autónoma Metropolitana, Unidad Iztapalapa, México, onde tive contatos com o professor Moisés L. de Guevara, em 1978, e na University of Western Australia, onde tive contatos com os etnólogos conhecidos na Austrália, professores Ronald e Catherine Berndt, no início de 1979. Entretanto, sem disponibilidade de bolsas de estudo e sem possibilidade de conseguir o visto de trabalho para poder coadunar trabalho e estudos, não foi possível iniciar o mestrado nestas Universidades.

Em 1979, fui aprovado na University of Cambridge, Inglaterra para cursar o Mestrado (M.Phil em Antropologia Social - 1979-1980) sob a orientação do professor Alan MacFarlane, com coorientação do professor Stephen Hugh-Jones, com apoio de uma bolsa de estudos da University of Leeds onde havia realizado a graduação.

Enquanto estava cursando o Mestrado em Antropologia Social na University of Cambridge, Inglaterra, solicitei uma bolsa de estudos no Brasil via Ministério de Relações Exteriores do Brasil que, na época, oferecia uma bolsa de 
estudos por ano para candidatos de nacionalidade britânica que queriam realizar cursos de pós-graduação no Brasil, junto com Miranda Scholarship da Fundação Miranda de São Paulo, que pagou minha passagem aérea ao Brasil. A concessão desta bolsa de estudos pelo governo brasileiro por meio da Embaixada do Brasil em Londres determinou , definitivamente, minha trajetória acadêmica e o Brasil como país onde realizei o doutorado em Antropologia e consolidei a minha carreira em Antropologia em um dos maiores centros de excelência acadêmica em Antropologia no Brasil, a UnB.

Comecei minha dissertação de mestrado na Universidade de Cambridge, Inglaterra, sobre "Política Indigenista Contemporânea no Brasil", defendida em julho de 1980, período em que obtive uma formação básica em Antropologia Social na Grã-Bretanha, passando por meu doutorado no DAN/UnB sob a orientação de um dos pesquisadores mais conhecidos na área de etnologia indígena, professor Julio Cezar Melatti, (1981-1988). Consolidei meu conhecimento sobre a Antropologia, especializei-me em etnologia indígena e realizei uma pesquisa de campo de longa duração (18 meses em comunidades indígenas) junto a um povo indígena, os Waimiri-Atroari, na região Norte-Amazônica, da família linguística caribe.

Além do apoio incansável do professor Melatti, contei também com o apoio inestimável do professor Roberto Cardoso de Oliveira. Participei, a partir de 1990, do seu projeto de pesquisa sobre "Estilos de Antropologia" na Universidade Estadual de Campinas (UNICAMP), com uma proposta de pesquisa comparativa em etnologia indígena no Brasil e na Austrália. Posteriormente, a parceria com o professor Roberto Cardoso de Oliveira se consolidou com a sua volta ao Centro de Pesquisa e Pós-Graduação sobre as Américas (CEPPAC/UnB - atualmente o Departamento de Estudos Latino-Americanos - ELA), quando me convidou a co-coordenar um projeto de pesquisa sobre "Nacionalidade e Etnicidade em Áreas de Fronteira”, em que apresentei uma proposta de pesquisa sobre os povos indígenas Makuxi e Wapichana na fronteira Brasil-Guiana.

Iniciei meus estudos no DAN/UnB, a partir de julho de 1980, como aluno especial, e ingressei na primeira turma do doutorado que foi implantado a partir de março de 1981. Cursei as principais disciplinas com os professores Julio Cezar Melatti e Roberto Cardoso de Oliveira.

Quando aluno de doutorado no DAN/UnB, animado pelo ambiente estimulante da antropologia praticada no Brasil, já me interessei pela possibilidade 
de seguir carreira acadêmica no Brasil e tentei, novamente, conseguir o visto permanente. Em 1985, por intermédio do professor João Pacheco de Oliveira Filho do Museu Nacional, Universidade Federal do Rio de Janeiro (UFRJ), que na época coordenava o setor indígena no Ministério da Reforma Agrária (MIRAD), e cujas publicações tornaram-se uma fonte de inspiração para minha trajetória acadêmica, consegui uma promessa de emprego para atuar no referido setor do MIRAD. Entretanto, após dois anos de trâmites burocráticos para obter o visto permanente, o MIRAD havia sido extinto. Consegui ativar minha carteira de trabalho por meio de um emprego de meio expediente, de 1986 ao início de 1988, em que organizava os documentos da biblioteca, com o apoio do professor Antônio Jacó Brand, então secretário executivo do Conselho Indigenista Missionário (CIMI), vinculado ao Conselho Nacional dos Bispos do Brasil (CNBB). O trabalho na biblioteca do CIMI reforçou meu conhecimento sobre o indigenismo da Igreja Católica e me abriu um panorama sobre a situação indígena no Brasil.

Após concluir a tese de doutorado no final de 1987 e defendê-la em março de 1988, passei o período de março de 1988 a maio de 1989 no setor de Antropologia do Museu Paraense Emílio Goeldi em Belém do Pará, então do Conselho Nacional de Desenvolvimento Científico e Tecnológico (CNPq), como pesquisador bolsista na modalidade de Bolsa de Desenvolvimento Regional, quando publiquei minha tese de doutorado em forma de livro, $E$ a FUNAI que sabe: a frente de atraçãoWaimiri-Atroari ${ }^{2}$ (1991), realizando concurso em 1988, no DAN/UnB, para onde voltei em 1989. Quanto à tese publicada em forma de livro, tomo a liberdade de citar a apresentação do professor Julio Cezar Melatti:

As preocupações de Stephen Baines com os problemas relativos ao contato interétnico são antigas. Ele, em sua dissertação de mestrado, realizada na Universidade de Cambridge, sob orientação de Alan Macfarlane, fazia uma apreciação de textos brasileiros que tratavam do tema. Certamente, ao matricular-se no Doutorado em Antropologia da Universidade de Brasília e propor como trabalho de pesquisa o estudo dos Waimiri-Atroari, não pretendia simplesmente se ater às relações entre os mesmos e os representantes da sociedade brasileira, mas também fazer uma descrição e análise do sistema sociocultural que esses índios até então mantinham. Mas ele encontrou os Waimiri-Atroari numa situação muito especial. Após secular contato conflituoso com a população regional, os Waimiri-Atroari estavam à mercê de uma frente de atração 
constituída por numerosos funcionários da FUNAI. Não que a situação dos Waimiri-Atroari fosse essencialmente diferente daquelas vividas por outras sociedades indígenas nos seus primeiros anos de contato, aceito ou imposto. Mas todos os problemas enfrentados pelos indígenas nessa situação pareciam ter suas cores mais acentuadas no caso dos Waimiri-Atroari. Desse modo, o contato interétnico junto aos postos de atração se impôs como tema ao pesquisador. Ao esperado desconforto de toda pesquisa de campo, vieram acrescentar-se a desconfiança e hostilidade ao antropólogo, tanto por parte de funcionários ocupantes de altos cargos da FUNAI, como principalmente daqueles diretamente envolvidos com os Waimiri-Atroari, quando não de representantes de empresas com interesses na área e até de entidades indigenistas alternativas. Mas, como bom pesquisador, Stephen Baines soube reverter a situação a seu favor, transformando os mal-entendidos, as meias-palavras, os cochichos, as zombarias, os insultos, as proibições arbitrárias de que era objeto, em preciosos dados a serem examinados. Aprendeu a tomar sua própria presença num determinado momento e local como catalizadora da expressão de preconceitos, atitudes de dominação ou subordinação, conflitos, identificações. E, assim, Stephen Baines foi desvelando passo a passo interesses, expectativas, receios, por trás dos discursos e das ações dos mais diversos agentes envolvidos na situação, desde as falas e relatórios apresentados ao pesquisador supostamente ingênuo ainda não introduzido na área indígena até, durante e após a pesquisa de campo, os cuidados, as reelaborações, as conversas com o etnólogo, culminando com evitações e recusas, pois talvez já soubesse demais.

Se, por um lado, Stephen Baines se mostrou um etnógrafo atento e perspicaz, a quem os próprios sonhos serviam como pistas para a elucidação de problemas, por outro, manteve-se sempre cuidadoso e informado com respeito à teoria. Sua interpretação se mantém dentro das tradições dos estudos brasileiros de contato interétnico, ainda que se colocando em posição bastante autônoma com respeito aos mesmos. Afinal, foi preciso dar conta de uma situação em que tudo é mais acentuado que em outras áreas de contato interétnico: a manipulação da identidade chega a um alto grau de mutabilidade e sutileza; a ação das frentes de expansão torna-se insignificante diante dos efeitos da instalação das grandes obras; noções e conceitos antropológicos, reinterpretados, são incluídos no discurso dos agentes do contato, que também reinterpretam os acontecimentos hist6ricos regionais; o próprio caráter contraditório das relações entre brancos e índios chega ao ápice quando os primeiros ensinam os Waimiri-Atroari a se comportarem conforme a imagem que fazem dos segundos.

Navegando em águas tão revoltas, Stephen Baines mantem-se equidistante das várias ideologias - a dos indigenistas da FUNAI, a dos indigenistas alternati- 
vos, a da população regional, a dos índios de outras etnias que trabalham na frente de atração, a das mineradoras - mas, dado ao seu acentuado relativismo, sem considerar sua própria interpretação como mais explicativa que as outras.

Convém lembrar que, apesar de ter escolhido a frente de atração como seu tema, Stephen Baines dispõe de dados sobre a cultura e a sociedade Waimiri-Atroari que poderão ser aproveitados em outros trabalhos, embora, por modéstia ou rigor, não os julgue satisfatórios.

Trabalhar como orientador de Stephen Baines foi sempre motivo, para mim, de emoções ambíguas. Se, por um lado, me era gratificante lidar com um pesquisador interessado, assíduo, que levava em consideração todas as ponderações e reparos, por outro, deprimia-me ter de conhecer informações sobre índios em tão triste situação. Mas, enfim, o trabalho chegou a bom termo e vi, com satisfação, a banca examinadora da tese aprová-la vivamente impressionada com seu trabalho, e mais contente ainda fiquei com a sua merecida publicação (Melatti, 1991).

A UnB tornou-se o centro acadêmico que escolhi para consolidar minha carreira e onde desenvolvi minhas pesquisas em etnologia indígena, ampliando o foco, a partir da proposta de Roberto Cardoso de Oliveira de "Estilos de Antropologia”, para uma pesquisa sobre a etnologia indígena na Austrália (a partir de 1991) e, posteriormente, no Canadá (a partir de 1995 com bolsas do governo canadense), além de manter pesquisas etnográficas no Brasil sobre nacionalidade e etnicidade entre povos indígenas que vivem em fronteiras internacionais (a partir de 1991), e a criminalização de indígenas no sistema penitenciário de Roraima (a partir de 2008). O estilo de etnologia indígena que se faz no Brasil se tornou o campo em que me inseri e para o qual tenho dedicado minha carreira acadêmica.

\section{Etnologia indígena no Brasil}

Após concluir o Mestrado em Antropologia Social, recebi uma oferta de uma bolsa para realizar o doutorado no Departamento de Antropologia da Universidade de Cambridge, resultado de um convênio entre o governo do Kuwait, a Universidade Americana no Cairo, Egito, e a Universidade de Cambridge, que restringia as áreas de pesquisas ao Egito ou ao Kuwait. Entretanto, ao saber da aprovação da minha solicitação de bolsa do Ministério de Relações Exteriores do Brasil, optei por fazer o doutorado na área de etnologia indígena na UnB, já havendo me familiarizado com obras da área de etnologia sul-americana de 
Julio Cezar Melatti, Roberto Cardoso de Oliveira, Roque de Barros Laraia, Alcida Rita Ramos, Kenneth Taylor, Peter Silverwood-Cope, Stephen Hugh-Jones, Christine Hugh-Jones, Peter Rivière e outros antropólogos que realizavam pesquisas junto a povos indígenas nas Terras Baixas da América do Sul.

No segundo semestre de 1980, cursei disciplinas no DAN/UnB e preparei um projeto de pesquisa para um estudo etnográfico junto ao povo indígena Waimiri-Atroari, nos estados do Amazonas e Roraima, povo que vinha acompanhando nas notícias e em viagens à região em 1975, 1976 e 1977. Depois de ter sido aprovado na seleção de doutorado do Programa de Pós-graduação em Antropologia Social (PPGAS/DAN) no final de 1980, iniciei, em 1981, o doutorado. Foram os contatos com o conjunto de professores do DAN/UnB que marcaram minha vida acadêmica, e as disciplinas cursadas no PPGAS/DAN/ UnB e a orientação tutorial que consolidaram a minha formação em Antropologia. Todas as disciplinas cursadas enfatizavam o estilo de Antropologia com sociedades indígenas que se faz no Brasil, caracterizado como uma "antropologia da ação” (Melatti, 1984) ou, o que Julio Cezar Melatti, Darcy Ribeiro e Roberto Cardoso de Oliveira intitulam como antropologia engajada, algo diferente da antropologia aplicada, por se destacar pelo envolvimento dos pesquisadores com os problemas sociais enfrentados pelos grupos estudados e um compromisso com a defesa dos seus direitos.

Entre janeiro de 1982 e agosto de 1985, realizei dezoito meses de pesquisa de campo junto ao povo indígena Waimiri-Atroari, dividida em várias etapas, pois todo ano tinha que voltar a Brasília para renovar o visto de estudante no Brasil, com bolsa de doutorado (da Coordenação de Aperfeiçoamento de Pessoal de Nível Superior - CAPES e, posteriormente do CNPq). Apliquei os conhecimentos adquiridos em etnologia indígena no DAN para elaborar uma tese usando noções como "linguagem de dominação", "discursos de dominação" e, posteriormente, após a instalação do Programa Waimiri-Atroari (PWA), a partir de abril de 1987, a noção de "autodeterminação dirigida", "indigenismo empresarial" para caracterizar uma política indigenista subordinada aos interesses de grandes empresas, da construção da Usina Hidrelétrica de Balbina (ELETRONORTE), e mineradoras que atuavam na Mina de Pitinga (Mineração Taboca) em terras desmembradas das terras indígenas delimitadas pelo sertanista Gilberto Pinto Figueiredo Costa, em 1971, após uma manipulação cartográfica que retirou 40\% da terra indígena original para favorecer essas duas empresas. Nesta nova política 
indigenista, a FUNAI passou suas obrigações de administrar esta terra indígena, como órgão indigenista do Estado, por meio de um convênio entre a FUNAI e a ELETRONORTE, a uma organização não-governamental, o Programa Waimiri-Atroari, cuja sede se localiza no edifício sede da ELETRONORTE em Brasília. Desta maneira, privatizou-se a administração indigenista do povo Waimiri-Atroari por um programa atrelado aos interesses de uma empresa que provocou a inundação de vastas extensões do seu território tradicional.

Encontrei na etnologia indígena que se faz no Brasil, sobretudo nos estudos sobre o contato interétnico, subsídios teóricos para abordar a situação crítica em que se encontravam os Waimiri-Atroari, seu território cortado pela rodovia BR-174, e, posteriormente, com uma porção desmembrada para servir os interesses tanto da ELETRONORTE que veio, em 1987, a inundar uma vasta área na parte sul da área desmembrada, quanto da Mineração Taboca que ocupou, de forma maciça, vasta área na parte norte desmembrada. Encontrei subsídios, sobretudo, nos estudos sobre o contato interétnico, e a noção de fricção interétnica de Roberto Cardoso de Oliveira (1981 [1964]), entretanto, revisando a noção para explicar a situação empírica da minha pesquisa de campo, em que os funcionários indígenas da frente de atração da FUNAI transmitiam aos capitães Waimiri-Atroari todas as contradições e ambiguidades inerentes à identidade de “índio civilizado” e "caboclo” (Baines, 1991[1988]). Lançaram mão da retórica do movimento indígena, de serem, junto com os Waimiri-Atroari, "índios também”, unidos na luta política contra os "brancos". Porém, manipulavam as ambiguidades das identidades étnicas acionadas na FAWA para seu próprio proveito. Ora se identificaram como "índios" contra os "brancos", ora como "índios civilizados" ou "caboclos" em oposição a "índios Waimiri-Atroari” / "índios bravos" vistos pejorativamente, ora como "peãos da FUNAI" em oposição ao "chefe branco", conforme o contexto e a intenção por meio de discursos de dominação (Baines, 1991[1988]). Estas categorias foram impostas por meio de relações interétnicas desmedidamente assimétricas de sujeição-dominação (Cardoso de Oliveira, 1984), acionando uma linguagem de dominação, e discursos de dominação que redefiniam a realidade para os Waimiri-Atroari (Baines, 1991[1988]).

Enquanto estava redigindo minha tese de doutorado na UnB, o Programa Waimiri-Atroari (FUNAI/ELETRONORTE), criado em abril de 1987, posterior a minha pesquisa de campo para o doutorado, assumiu a administração indigenista na Terra Indígena Waimiri-Atroari, programa indigenista assistencia- 
lista divulgado através de campanhas de propaganda em nível nacional e internacional como um caso exemplar de indigenismo, apoiado por grandes empresas e com recursos do Banco Mundial. A Mineração Taboca e outras empresas mineradoras do então Grupo Paranapanema, abriram a mina de Pitinga, que se tornou uma das maiores minas de cassiterita (minério de estanho) do mundo, numa área que foi posteriormente desmembrada do território dos Waimiri-Atroari por meio de manipulações cartográficas (Baines, 1991a; 1991b; 1999). No mesmo período, a ELETRONORTE construiu a Usina Hidrelétrica de Balbina, inundando uma área de cerca de 2.928,5 km2 (Baines, 1996) que foi desapropriada da reserva original dos Waimiri-Atroari. Este exemplo revela "uma nova estratégia das grandes empresas de mineração em colaboração com o Estado - favorecer a demarcação e homologação da área indígena e exercer seu poder econômico para aliciar as novas lideranças indígenas a assinar acordos diretos entre as comunidades indígenas e as empresas, em nome de uma 'autodeterminação indígena'” (Baines, 1993:239). Em junho de 1989, na véspera da minha "expulsão" da Terra Indígena, tramada por funcionários do PWA, acordos foram assinados entre o Grupo Paranapanema e líderes Waimiri-Atroari, dando direitos exclusivos à Mineração Taboca para pesquisa e lavra de minérios na Terra Indígena Waimiri-Atroari. Contudo, os acordos foram suspensos enquanto não houvesse legislação complementar para regulamentar a pesquisa e lavra de mineração em terras indígenas.

A Terra Indígena Waimiri-Atroari serviu como um modelo empresarial para o planejamento de estratégias para a implantação "regularizada" de grandes projetos de desenvolvimento regional em terras indígenas na Amazônia, tanto de mineração quanto de Usinas Hidrelétricas, e influenciou na própria formulação da Constituição durante o ano de 1987, com forte lobby das empresas mineradoras lideradas pelo Grupo Paranapanema. Este lobby conseguiu, no texto constitucional, legalizar a mineração em terras indígenas a empresas mineradoras privadas. Na Constituição anterior de 1967, a mineração em terras indígenas foi restrita a empresas estatais e a minérios estratégicos, mesmo que muitas empresas privadas burlassem a Constituição. Conforme a Constituição de 1988, "O aproveitamento dos recursos hídricos, incluídos os potenciais energéticos, a pesquisa e a lavra das riquezas minerais em terras indígenas só podem ser efetivados com autorização do Congresso Nacional, ouvidas as comunidades afetadas, ficando-lhes assegurada participação nos resultados da lavra, na forma da lei” (Art. 
$\left.231,3^{\circ}\right)$. Assim, a regulamentação das questões de mineração e a implantação de Usinas Hidrelétricas foram remetidas à legislação complementar posterior.

A experiência de pesquisa de campo para o doutorado e para depois dele apresentou-se como campo privilegiado para examinar as estratégias de grandes empresas para se adaptarem aos direitos indígenas incorporados na Constituição Brasileira de 1988. O Programa Waimiri-Atroari passou a ser usado como publicidade para justificar a implantação de usinas hidrelétricas em territórios indígenas na região amazônica, incorporando as lideranças Waimiri-Atroari como porta-vozes da propaganda. Enquanto no período da ditadura militar as grandes empresas invadiam territórios indígenas, criando fatos consumados que foram posteriormente legalizados, uma nova estratégia adotada após a nova Constituição era de criar simulações de relações interétnicas harmoniosas entre as empresas e os povos indígenas. Imagens de indígenas que apoiam os programas indigenistas, o discurso do seu supervisor de que o Programa Waimiri-Atroari “conseguiu colocar em prática o que todos os indigenistas sonhavam”, e a existência de representantes de um povo indígena (o povo Waiwai), maravilhados com as "riquezas" do Programa Waimiri-Atroari, solicitando a construção de uma grande hidrelétrica (a de Cachoeira Porteira no rio Trombetas) para ganhar uma indenização parecida em troca da inundação das suas terras, combinam bem com a declaração do presidente da ELETRONORTE de que a Usina Hidrelétrica Belo Monte (que seria uma das maiores do mundo) é a obra de seus sonhos (Pinto, 1998), para tentar reverter as críticas e acelerar a aprovação de mais megaprojetos de usinas hidrelétricas na região amazônica.

\section{Noções e conceitos teóricos}

Na minha tese de doutorado, "É a FUNAI que sabe: a frente de atração Waimiri-Atroari”, defendida na UnB em 1988, realizei uma etnografia de uma frente de atração da FUNAI no momento histórico antes de os Waimiri-Atroari serem incorporados dentro de um indigenismo empresarial do Programa Waimiri-Atroari, criado em abril de 1997, seis meses antes do fechamento das comportas da Usina Hidrelétrica de Balbina e inundação de uma vasta área do território tradicional deste povo indígena.

Iniciei o doutorado com projeto de pesquisa que focalizava o contato interétnico a partir das noções de "fricção interétnica" de Cardoso de Oliveira (1986). $\mathrm{Na}$ maioria dos trabalhos que seguem o modelo de fricção interétnica, as duas 
populações do sistema interétnico (Cardoso de Oliveira, 1978:85) são tomadas como dois grupos empíricos de "índios" e "brancos". Na Frente de Atração Waimiri-Atroari, um contingente grande dos funcionários identificava-se como "índio", e muitos deles acionavam, em alguns contextos, um discurso indigenista que invertia a ideologia hegemônica, valorizando a categoria genérica de "índio" e desprezando a de "branco". Acionavam esse discurso como estratégia para incentivar os Waimiri-Atroari a rejeitar indivíduos que os mesmos funcionários "índios" classificaram como "brancos". Enfrentei esta manipulação de identidade étnica pelos servidores "índios" desde a minha chegada ao território Waimiri-Atroari. Os Waimiri-Atroari pediam para eu repetir “A' wo Ka'amin' ya (sou "civilizado") identidade altamente pejorativa no discurso indigenista destes servidores. Diante disso , não fazia sentido tratar da situação de contato, através da noção de fricção interétnica, sem examinar a oposição "índio"/"branco". Nesta Frente de Atração, uma grande parte da população dominadora era constituída de indivíduos que se identificavam como "índios". As relações de sujeição/ dominação estabelecidas pela equipe de servidores não correspondiam às relações entre "índios" e "brancos". Correspondiam a discursos diversos que mudavam conforme o contexto.

Equiparar os termos "índio" e "branco" a dois grupos empíricos seria, na Frente de Atração Waimiri-Atroari, ver a situação da perspectiva dos "brancos" e assim reafirmar a ideologia hegemônica, considerando que a população dominadora, com relação aos Waimiri-Atroari, era constituída de "índios” e "brancos". Neste caso, a oposição "índio"/"branco" somente poderia ser considerada dentro do contexto dos discursos da Frente de Atração. Aqueles servidores que apelavam à identidade "índio", ao apresentá-la como referencial identificador de todas as pessoas classificadas por eles como "índios" (a maioria dos funcionários da FUNAI e os Waimiri-Atroari) em oposição a "brancos", ofereciam uma visão que encobria e disfarçava as relações assimétricas e contraditórias de sujeição/ dominação entre os Waimiri-Atroari e os servidores. Isso conduzia os "brancos" (do discurso dos servidores) a acreditarem que aqueles servidores classificados como "índios" aproximavam-se mais dos Waimiri-Atroari. Muitos dos funcionários "índios” apelavam a um discurso pan-indianista para, nesta situação, legitimar sua manipulação dos Waimiri-Atroari.

Neste caso, há de se tomar em consideração os discursos que manipulavam a identidade étnica. Em uma situação como a da Frente de Atração Waimiri- 
-Atroari (FAWA), renomeado Núcleo de Apoio Waimiri-Atroari (NAWA), um segmento dos agentes sociais da sociedade dominante (a FAWA) com relação aos Waimiri-Atroari apresentava-se como "índio" em oposição a "branco". Ao mesmo tempo, estes funcionários "índios" invertiam as relações de sujeição-dominação "índio"/"branco", ao assumirem o papel de dominadores. Este exemplo mostra como os protagonistas da situação de contato se tornam "índios", e "brancos" em oposição àqueles, na medida em que a população dominadora a determinava por meio de um discurso de dominação.

A noção de fricção interétnica, altamente aplicável para trabalhos que objetivam uma análise da situação de contato em que são privilegiadas as relações sociais entre uma população indígena e os diversos segmentos da sociedade nacional, dentro de uma perspectiva regional, tem sido usada, partindo da pressuposição de que os representantes da sociedade nacional são constituídos de "brancos". Ao abordar a situação em que se encontravam os Waimiri-Atroari, privilegiei a manipulação de identidade étnica pelos funcionários da FUNAI referidos como "braçais", que dependem da autodefinição.

Para captar o que estava acontecendo nesta Frente de Atração, considerei mais proveitoso tratar das identidades como parte constitutiva dos discursos. Examinei os discursos dos agentes sociais não somente pelo seu conteúdo, mas também no seu contexto, uma abordagem que não definia a priori as identidades das populações em contato. A Frente de Atração Waimiri-Atroari reencenava, por meio do indigenismo do Estado, a prática secular das "guerras justas" e os "descimentos" em que a sociedade colonial recrutava os chamados "índios mansos" como "tropas de resgate" contra outros povos indígenas que ainda não haviam sido conquistados (Farage, 1991).

Por toda a tese de doutorado, focalizei as relações sociais de sujeição-dominação desmedidamente assimétricas, estabelecidas entre os agentes da sociedade nacional e os Waimiri-Atroari. Procurei mostrar como, em uma situação de pesquisa de campo, o fato de que a dinâmica do encontro pode ser mais reveladora do que o encontro em si, o que fica patente na situação de uma Frente de Atração.

Usei a noção de "instituição total” de Erving Goffman (1961), pois as relações sociais nesta frente de atração tomavam a forma de uma instituição total dividida entre uma equipe dirigente de funcionários da FUNAI e internados Waimiri-Atroari, embora agravada neste caso por classificações étnicas e o racismo. 
Nesta situação, o pesquisador foi enquadrado entre os "dominadores", o que levou os "dominados" (segundo o discurso de dominação imposto pela equipe dirigente) a construírem um discurso de "índio" para "branco". Para a equipe dirigente, cujos membros se classificavam ora como "índios", ora como "índios civilizados", e ora como "brancos" conforme seus interesses em explorar a situação, os Waimiri-Atroari aprenderam um discurso de internados, (Goffman, 1961). Examinei a linguagem, tanto verbal quanto não-verbal, não somente pelo que expressava, mas pelos atos locucionários, ilocucionários e perlocucionários (Austin, 1962; Searle, 1969).

Procurei mostrar como, por meio de discursos de dominação, a sociedade dominante impõe suas representações da sua "realidade", que indicam e prescrevem aos dominados o que devem pensar e como devem pensar, o que devem valorizar e como devem valorizar, o que devem sentir e como devem sentir, o que devem fazer e como devem fazer, e, além disso, o que devem ser e como devem ser. Recorri às noções de "linguagem de dominação" e "discursos de dominação".

Após a publicação do livro "E a FUNAI que sabe": a frente de atração Waimiri-Atroari em Belém, Pará, Museu Paraense Emílio Goeldi, Coleção Eduardo Galvão, que foi entregue para publicação em 1988 e publicado em 1992 [1991], em publicações posteriores, elaboro a noção de "indigenismo empresarial”, um indigenismo privatizado por empresas que têm interesses diretos nas terras dos povos indígenas em que administram a política indigenista, e desta maneira, um indigenismo atrelado aos interesses econômicos das empresas.

Publiquei também, em francês, o artigo:

- "Les Waimiri-Atroari et la Compagnie Paranapanema: Chronique d'une expropriation officielle" in Ethnies: Droits de l'homme de peuples autochtones, Printemps 1990, Vol. 5, no. 11 12, Survival International, (France), Paris, p. 33-37, e logo depois, um artigo em inglês em periódico internacional:

- "Dispatch: The Waimiri-Atroari and the Paranapanema Company". Critique of Anthropology, Vol.11 (2): 143-153, 1991. Sage Publications, London, Newbury Park and New Delhi, e "Dispatch II.Anthropology and Commerce in Brazilian Amazonia: Research with the Waimiri-Atroari banned”. Critique of Anthropology, Vol.11 (4): 395-400, 1991. Sage Publications, London, Newbury Park and New Delhi.

No ano seguinte, publiquei o artigo:

- La Raison Politique de l'Ignorance ou l'Etnologie Interdite Chez lesWaimiri-Atro- 
ari, no periódico quebequense, Recherches Amérindiennes au Quebec, vol.XXII, N ${ }^{\circ}$ 1, 1992, p. 65-79, Montreal, Canadá.

Vários papers de debate sobre a pesquisa junto aos Waimiri-Atroari foram divulgados na Série Antropologia do DAN/UnB, em que desenvolvo o conceito de “autodeterminação dirigida” (Baines, 1992) para descrever o processo de incorporação de lideranças Waimiri-Atroari na administração indigenista, a partir de uma retórica de autodeterminação indígena controlada pelos dirigentes do Programa Waimiri-Atroari e subordinada aos interesses da empresa, como, "A Política Indigenista Governamental e os Waimiri-Atroari: Administrações Indigenistas, Mineração de Estanho e a Construção de 'autodeterminação indígena' dirigida”. Série Antropologia, 126, Brasília, DAN/UnB, 1992, 28p.

Desenvolvo a noção de "indigenismo empresarial”, um indigenismo privatizado por empresas que atuam no território indígena que substituiu o indigenismo do Estado. Neste caso, um programa assistencialista - O Programa Waimiri-Atroari (PWA) - administrado por uma organização não governamental atrelada à própria ELETRONORTE e subordinada às consequências nefastas da inundação de vastas extensões do território Waimiri-Atroari pela construção da Usina Hidrelétrica Balbina. O indigenismo empresarial coloca os Waimiri-Atroari em situação de relações sociais de extrema assimetria e sem alternativas, a não ser cumprir as ordens que vêm dos indigenistas do setor elétrico. A noção de "indigenismo empresarial" (Baines, 1991a, 1993a) refere-se a um indigenismo que incorpora a dinâmica das pressões empresariais sobre os próprios indígenas e visava a sua redefinição como "índios civilizados”, obedientes cumpridores de ordens, recrutados como porta-vozes indígenas da própria administração indigenista. O indigenismo empresarial constantemente subordina a população indígena aos interesses das empresas que exercem poderes econômicos que sobrepujam os da FUNAI, e tem o poder da mídia para criar e veicular imagens dos Waimiri-Atroari, construídas conforme os interesses da empresa, em nível nacional e internacional. Estas ideias são elaboradas em artigos:

- "O Território dos Waimiri-Atroari e o Indigenismo Empresarial”. Série Antropologia, 138, Brasília, DAN/UnB, 1993;

- “Censuras e Memórias da Pacificação Waimiri-Atroari”. Série Antropologia, 148, Brasília, DAN/UnB, 1993, artigo traduzido para o inglês, "Government Indigenist Policy and theWaimiri-Atroari Indians: Indigenist Administrations, Tin Mining and 
the Construction of directed Indian 'Self-determination' in Brazilian Amazonia”. Série Antropologia, 152, Brasília, DAN/UnB, 1993.

O caráter de deslocamento compulsório é tratado no artigo:

- "A Usina Hidrelétrica de Balbina e o Deslocamento Compulsório dos Waimiri-Atroari”. Série Antropologia, 166, Brasília, DAN/UnB, 1994”, e seus impactos sobre pesquisas etnográficas independentes do Programa indigenista na seguinte publicação "Política Indigenista Governamental no Território dos Waimiri-Atroari e Pesquisas Etnográficas”. Série Antropologia 225, DAN/UnB, outubro de 1997.

Abordo, também a história de contato interétnico e o papel das epidemias na depopulação drástica deste povo indígena, sobretudo nos primeiros anos da invasão e ocupação do seu território por agentes da sociedade nacional no artigo:

- "Epidemics, the Waimiri-Atroari Indians, and the Politics of Demography". Série Antropologia, 162, Brasília, DAN/UNB, 1994, trabalho preparado para o $48^{\circ}$ Congresso Internacional de Americanistas, Uppsala, Suécia, 03-08 julho de 1994.

O tema do indigenismo empresarial e suas influências totalizantes sobre a povo indígena é abordado em:

- "Os Waimiri-Atroari e a Invenção Social da Etnicidade pelo Indigenismo Empresarial”. Série Antropologia 179, DAN/UnB, 1995, e a resistência indígena frente ao indigenismo de resistência, em "A Resistência Waimiri-Atroari frente ao ‘Indigenismo de Resistência””. Série Antropologia, 211, Brasília, DAN/UnB, 1996.

Em trabalho divulgado posteriormente, reflito sobre o uso de imagens de lideranças Waimiri-Atroari nas campanhas intensivas de marketing da ELETRONORTE, nominado:

- "Imagens de liderança indígena e o Programa Waimiri-Atroari: Índios e Usinas Hidrelétricas na Amazônia”. Série Antropologia 246, DAN/UnB, 1999, 16 páginas.

Alguns destes artigos divulgados na Série Antropologia foram, posteriormente, revisados e republicados em periódicos como, por exemplo:

- “O Território dos Waimiri-Atroari e o Indigenismo Empresarial”. Ciências 
Sociais Hoje, 1993, São Paulo, HUCITEC/ANPOCS, 1993:219-243;

- "A Política Indigenista Governamental e os Waimiri-Atroari: Administrações Indigenistas, Mineração de Estanho e a Construção de 'Autodeterminação Indígena’ Dirigida”, Revista de Antropologia da Universidade de São Paulo, Volume 36, 1994:207-237;

- "Uma tradição indígena no contexto de grandes projetos: os Waimiri-Atroari”. Anuário Antropológico 96, DAN/UnB, 1997:67-81;

- "Os Waimiri-Atroari e a Invenção Social da Etnicidade pelo Indigenismo Empresarial”. Anuário Antropológico 94, Rio de Janeiro: Tempo Brasileiro, 1995:127-159;

- "A Usina Hidrelétrica de Balbina e o Deslocamento Compulsório dos Waimiri-Atroari”, publicado no livro organizado por MAGALHÃES, Sônia Barbosa; BRITTO, Rosyan de Caldas; e CASTRO, Edna Ramos de (orgs.) Energia na Amazônia. Belém: MPEG, UFPa, UNAMAZ, 1996:747-759.

Outros artigos sobre os Waimiri-Atroari foram publicados em periódicos como uma reflexão sobre um dos últimos líderes deste povo indígena que tentou lutar contra a invasão dos seus territórios:

- "Comprido: A morte de um líder Waimiri-Atroari”, Boletim do Museu Paraense Emílio Goeldi, Série Antropologia, 6(2), 1990:145-160;

- "Waimiri-Atroari" in Encyclopedia of World Cultures, (org. David Levinson), Vol. VII South America, (org. de volume Johannes Wilbert) (Human Relations Area Files, Inc., New Haven, Connecticut), G.K. Hall \& Co., Boston, Massachusetts, 1994:341-345.

Divulguei, também, artigo de resenha:

- "Brasil e Grã-Bretanha disputam o território Makuxi. Review article of RIVIÈRE, Peter. 1995. Absent Minded Colonialism: Britain and the Expansion of Empire in Nineteenth-Century Brazil. London, New York: Taurus Academic Studies, I.B.”, que foi publicado no Anuário Antropológico 95, Rio de Janeiro: Tempo Brasileiro, 1996:265-274;

- "O impacto da escrita na sociedade Waimiri-Atroari". Cadernos de Linguagem e Sociedade, Vol.2, N.1, entregue em 1996:9-26 (publicado em 1997);

- "Waimiri-Atroari resistance in the presence of an indigenist policy of 'resistance'”, Critique of Anthropology, 19(3) 1999:211-226; 
- "The reconstruction of space in an indigenous society: the Waimiri-Atroari". Espaço e Geografia, No.1, Ano 1, 1998:59-79. UnB/Departamento de Geografia.

- "Imagens de liderança indígena e o Programa Waimiri-Atroari: índios e usinas hidrelétricas na Amazônia”. Revista de Antropologia (São Paulo), v. 43, p. 141-163, 2000.

Após a proibição de todas as pesquisas em antropologia não subordinadas à administração indigenista, por parte de dirigentes do Programa Waimiri-Atroari e sem a possibilidade de dar continuidade à pesquisa junto aos Waimiri-Atroari, focalizei nos meus trabalhos publicados a partir da minha própria "expulsão" desta Terra Indígena, em junho de 1989, e nas estratégias das grandes empresas que atuam em territórios indígenas. Se antes, na tese de doutorado, a descrição e a análise da violência cotidiana da Frente de Atração pareciam uma denúncia, os trabalhos posteriores denunciam a corrupção e violência do Programa Waimiri-Atroari em impor um indigenismo empresarial.

Além de manter um forte interesse em políticas indigenistas, e de acompanhar os povos indígenas atingidos pelas consequências nefastas de mega-projetos desenvolvimentistas, evidentes em minhas publicações ao longo dos últimos vinte e sete anos (até 2015), e na organização de Grupos de Trabalho, Simpósios e Mesas Redondas internacionais e nacionais que refletem sobre esta temática, entre os anos de 2008 e 2010, participei como representante titular da Associação Brasileira de Antropologia (ABA) junto ao Ministério de Relações Exteriores (MRE), da Câmara Temática Conhecimento Tradicional Associado do Ministério do Meio Ambiente (MMA), a convite do então presidente da ABA, Professor Carlos Caroso, da Universidade Federal da Bahia (UFBA).

Em 2014, fui convidado pelo professor Russell Parry Scott da Universidade Federal de Pernambuco (UFPE) para participar do Comitê Povos Tradicionais, Meio Ambiente e Grandes Projetos da ABA e, em 2015, fui convidado pelo professor Antônio Carlos de Souza Lima (Museu Nacional/UFRJ) para ser vice-coordenador do Comitê Povos Tradicionais, Meio Ambiente e Grandes Projetos da ABA para o biênio 2015-2016. Atualmente, sou coordenador do mesmo comitê na gestão 2017-2018. 


\section{Etnografando a etnologia indígena no Brasil e em outros Estados Nacionais - estilos de etnologia em contextos nacionais}

Primeiramente, explico como fiz a passagem de realizar pesquisa em etnologia indígena a um projeto de pesquisa com objetivo de etnografar os estilos de etnologia em contextos nacionais diversos, ao mesmo tempo em que mantenho pesquisas ativas em etnologia indígena. Em junho de 1989, fiquei decepcionado por ter minha pesquisa junto ao povo indígena Waimiri-Atroari interrompida por uma campanha de calúnias montada por dirigentes do Programa Waimiri-Atroari (ELETRONORTE/FUNAI), como parte de uma proibição a todas as pesquisas independentes em Antropologia junto aos Waimiri-Atroari, feita pelo Programa, assim que assumiu a administração indigenista deste povo indígena. Proibição que começou com a interrupção da pesquisa do professor Márcio Ferreira da Silva, que foi impedido de continuar sua pesquisa junto aos Waimiri-Atroari em 1997, após ter realizado sete meses de trabalho de campo para o doutorado no Museu Nacional/UFRJ sob a orientação do professor Eduardo Viveiros de Castro. Em junho de 1989, quando eu era pesquisador do Museu Goeldi, com bolsa de Desenvolvimento Regional do CNPq, indigenistas da direção do Programa Waimiri-Atroari montaram uma campanha de calúnias junto às lideranças Waimiri-Atroari, apresentando-me como se fosse um agente internacional, supostamente trabalhando para empresas mineradoras internacionais e usando os Waimiri-Atroari para tentar impedir que os mesmos indígenas entrassem em acordos diretos com a Mineração Taboca e outras mineradoras do então Grupo Paranapanema.

A minha "expulsão" da Terra Indígena Waimiri-Atroari por meio desta campanha de calúnias coincidiu com minha aprovação em concurso público no DAN/ UnB em março de 1988. Apesar de aproveitar ao máximo a minha estadia no Museu Paraense Emílio Goeldi em Belém do Pará, experiência muito rica como bolsista do $\mathrm{CNPq}$, aproveitei a oportunidade para me transferir e para assumir o lugar de professor do DAN/UnB em maio de 1989, onde permaneço até hoje como professor titular, desde 2015.

$\mathrm{Na}$ campanha feita contra minha presença como pesquisador em etnologia indígena pelo Programa Waimiri-Atroari, uso foi feito de matérias jornalísticas caluniosas publicadas no jornal $O$ Estado de São Paulo ao longo de uma semana, em agosto de 1987, em uma campanha contra o Conselho Indigenista Missionário (CIMI) ligado ao Conselho Nacional de Bispos do Brasil (CNBB) - onde 
eu havia trabalhando em tempo parcial como assistente na biblioteca em 19861988 - em que meu nome, alterado na ortografia pelo autor das matérias, entretanto reconhecível, apareceu em duas matérias, me apresentando como se fosse um agente de um cartel de estanho internacional "Tin Brothers da Malásia” (Baines, 1993). Apesar de uma Comissão Parlamentar de Inquérito, realizada na segunda metade de 1987, comprovar que as matérias pagas eram falsas e preparadas por Mauro Nogueira, estelionatário então procurado pela Polícia Federal no Pará e no Maranhão, contratado por dois meses pelo então diretor geral do Grupo Paranapanema, Octávio Lacombe (do qual, na época, a Mineração Taboca fazia parte), com a finalidade de montar uma campanha falsa contra o CIMI e pressionar, no período do Constituinte, para a inclusão de uma cláusula na Constituição Federal de 1988 que permitiria mineração em Terras Indígenas por empresas privadas (na Constituição anterior, atividades de pesquisa e lavra de mineração eram restritas a empresas estatais e minérios classificados como estratégicos), dirigentes do Programa Waimiri-Atroari reutilizaram essas matérias. A reutilização foi feita quase dois anos depois de terem sido desmascaradas tais matérias que intencionavam ludibriar as lideranças Waimiri-Atroari para proibir a minha pesquisa em etnologia sob o pretexto de eu não ser antropólogo, mas agente internacional que, supostamente, teria ludibriado os Waimiri-Atroari ao longo de mais de oito anos de pesquisa, e dezoito meses de pesquisa de campo junto ao povo Waimiri-Atroari. Tentei conseguir direito de resposta no jornal, e fui encaminhado, na época, ao então procurador Gilmar Mendes no Ministério Público Federal onde o mesmo disse que contra grandes empresas do porte da ELETRONORTE e da Mineração Taboca eu não teria nenhuma possibilidade de ganhar direito de resposta. Sugeriu que evitasse voltar para a Terra Indígena Waimiri-Atroari por algum tempo e, caso viesse a sofrer ameaças em Brasília, deveria procurar o Ministério Público Federal (MPF).

Assumi como professor de antropologia do DAN/UnB, em maio de 1989, no meio de uma greve e comecei a dar aulas em agosto 1989, assim que terminou a greve. Senti-me decepcionado pelo fato de que uma campanha de mentiras que surgiu de dentro da direção do Programa Waimiri-Atroari - administração indigenista que se apresentava em campanhas intensivas de marketing como se fosse não apenas um sucesso, mas uma "revolução no indigenismo brasileiro" (Hart, 1991) - pudesse interromper uma pesquisa etnológica junto a este povo indígena de quem eu havia ganhado a confiança e colaboração da maioria e estava 
em processo de aprendizado da língua indígena, após ter realizado dezoito meses de pesquisa de campo. E, sobretudo, desapontado em ver um povo indígena inteiro em situação de submissão e ludíbrio por uma administração indigenista construída em cima de mentiras e corrupção.

Em 1989, aceitei, com muito interesse, um convite do professor Roberto Cardoso de Oliveira que, junto com o professor Julio Cezar Melatti, havia sido uma constante fonte de apoio durante os anos em que fui estudante do doutorado na UnB, para fazer parte da sua equipe de pesquisa sobre Estilos de Antropologia, na UNICAMP, São Paulo. Na época, o professor Cardoso de Oliveira estava implantando um programa de doutorado na UNICAMP. Solicitei uma bolsa de produtividade em pesquisa ao CNPq e, a partir de março de 1990, iniciei um projeto de pesquisa para realizar uma pesquisa comparativa sobre a etnologia indígena na Austrália, país onde eu havia passado três meses em 19781979, visitando comunidades indígenas no norte e centro do país. Participei do projeto de pesquisa coordenado por Cardoso de Oliveira, viajando, no início de 1992, à Austrália para realizar um primeiro levantamento de pesquisa em três de seus principais centros de etnologia indígena: a Universidade de Sydney, a Australian National University (ANU) em Camberra, e a University of Western Australia na cidade de Perth.

Entrevistei alguns dos etnólogos mais conhecidos da Austrália e aproveitei para visitar outras universidades e centros de pesquisa em etnologia indígena, como Macquarie University em Sydney, Curtin University em Perth, e a Australian Institute for Aboriginal e Torres Strait Islander Studies (AIATSIS) em Camberra. As entrevistas foram feitas com trinta e seis etnólogos, vários pesquisadores em outras áreas de estudo, três antropólogos consultores, e cinco lideranças indígenas. Eu já havia passado três meses na Austrália em 1979, quando que visitei comunidades indígenas na Austrália Ocidental e no Território do Norte.

Meu objetivo, no levantamento de 1992, era examinar a etnologia indígena que se faz na Austrália, a partir da minha formação acadêmica em nível de doutorado no Brasil, onde resido desde 1980, sendo brasileiro naturalizado desde 1991. Esta primeira etapa de pesquisa sobre o estilo de etnologia indígena que se pratica na Austrália, além de ser uma fonte de material para a publicação de artigos, serviu para a formação de alunos em níveis de Pós-Graduação e Graduação em Antropologia na UnB, como parte de um esforço para a internacionalização da disciplina. 
Em 1995, consegui uma bolsa do governo canadense para passar cinco semanas no Canadá, realizando um levantamento sobre a etnologia indígena naquele país, como no caso da Austrália, sempre usando a etnologia indígena que se faz no Brasil como ponto de partida. Neste primeiro levantamento, em Montreal, Quebec, realizei visitas à principal universidade francófona, a Université de Montréal, e à principal universidade anglófona, McGill University, além de entrevistar professores de Concordia University. Visitei, também, a Université Laval na cidade de Quebec, e em Toronto, a University of Toronto, além de visitar a University of Waterloo em Ontário. De Toronto, atravessei o Canadá de ônibus à cidade de Kamloops, na província da Colúmbia Britânica, onde visitei o Program of First Nation Studies of the Secwepemc (Shuswap) Cultural Education Society e a Simon Fraser University (SCES/SFU), em Kamloops; as reservas indígenas Shuswap de Adam's Lake e Skeetchestn; a University of Northern British Columbia (UNBC) na cidade de Prince George; a reserva indígena Witsuwit'en de Moricetown; a University of British Columbia (UBC) e Simon Fraser University em Vancouver; e a University of Victoria na capital da Colúmbia Britânica, Victoria.

Durante as referidas cinco semanas no Canadá, entrevistei vinte e nove antropólogos que realizam pesquisas junto com povos indígenas no Canadá (três dos quais se identificaram como indígenas) e fiz contatos com mais quatro. A maioria dos antropólogos entrevistados são professores universitários, e uma trabalhava em um departamento do governo. Entrevistei, também, quatro lideranças indígenas (um dos quais estava trabalhando no seu doutorado em etnohistória e outra mestranda em antropologia), um ecólogo que realiza pesquisa com povos indígenas, um cientista político e três historiadores.

Destas pesquisas, divulguei diversos trabalhos iniciais sobre a etnologia em contextos nacionais, primeiro na Série Antropologia, do DAN/UnB como:

- "Etnologia e Indigenismo na Austrália. Série Antropologia, 115, Brasília, DAN/UnB, 1991.

- "Primeiras Impressões sobre a Etnologia Indígena na Austrália". Série Antropologia, 139, Brasília, DAN/UnB, 1993.

- "First Impressions from a Brazilian Perspective on the Study of Aboriginal Populations in Social Anthropology in Australia”. Série Antropologia, 144, Brasília, DAN/ UnB, 1993.

- "Etnologia Indígena no Canadá: Primeiras Impressões”. Série Antropologia, 
196, Brasília, DAN/UnB, 1996.

- "Social Anthropology with Aboriginal Peoples in Canada: First Impressions". Série Antropologia, 197, Brasília, DAN/UnB, 1996.

- "Tendências recentes na Política Indigenista no Brasil, na Austrália e no Canadá”. Série Antropologia 224, DAN/UnB, outubro de 1997.

Posteriormente, publiquei alguns destes artigos revisados e atualizados, e outros relacionados à etnologia indígena em geral, em livros e periódicos:

- "Primeiras impressões sobre a etnologia indígena na Austrália” In CARDOSO DE OLIVEIRA, Roberto \& Guillermo Raul RÚBEN (orgs.) Estilos de Antropologia, Campinas: Editora da UNICAMP, (Coleção Repertórios), 1995: 65-119.

- "Review Article" - Versão adaptada em inglês de resenha de livro TRIGGER, David S. Whitefella comin': Aboriginal responses to colonialism in Northern Australia. Cambridge University Press, 1992. Bijdragen BKI 150-III (1994), p. 568-581.

- O artigo de resenha do livro organizado por Oliveira, João Pacheco de (org.) 1998: Indigenismo e Territorialização: poderes rotinas e saberes coloniais no Brasil contemporâneo. Rio de Janeiro: ContraCapa Livraria. 310 pp. In: Mana, 5(1), 1999, p. 171-174.

Em 2002, consegui outra bolsa do governo canadense para passar três semanas em três centros no leste do Canadá - Montreal, Ottawa e Toronto, quando aprofundei a pesquisa iniciada em 1995, e em 2009-2010 realizei onze meses de pesquisa de pós-doutorado, cinco meses na University of British Columbia (UBC), no Canadá, de 1 de setembro de 2009 até o final de janeiro de 2010, sob a supervisão acadêmica do professor Bruce Granville Miller, e seis meses na Australian National University (ANU), de 01 de fevereiro de 2010 a 01 de agosto de 2010, sob a supervisão acadêmica da professora Francesca Merlan. Foram períodos de imersão em dois dos principais centros e comunidades acadêmicas em etnologia indígena nestes países, o que permitiu avanços sem precedentes na compreensão da enorme diversidade e complexidade das áreas de etnologia indígenas no Canadá e na Austrália, como também no Brasil. Os onze meses de licença pós-doutoral no Canadá e na Austrália, em 2009-2010, permitiram um enorme avanço em minhas pesquisas sobre estilos de etnologia indígena em contextos nacionais. 


\section{Pesquisas sobre estilos de Etnologia Indígena}

Para resumir a linha de pesquisa que desenvolvo sobre estilos de etnologia indígena, julgo necessário relatar alguns dos temas trabalhados, apontando os principais autores e ideias que influenciaram minha pesquisa. Nestas pesquisas, parti de uma abordagem comparativa, focalizando três Estados nacionais: Brasil, Canadá e Austrália. A partir de um enfoque nos diferentes contextos históricos, culturais e institucionais em que se desenvolveu a etnologia indígena, analisei algumas das diferenças óbvias na disciplina nos três contextos nacionais para depois comparar determinadas semelhanças entre esses três países de colonização europeia. Observei, também, tendências associadas a um processo crescente de globalização, que estão aproximando as situações de povos nativos e os estilos de antropologia em projetos de pesquisa colaborativos e participativos por meio de um intercâmbio mais próximo de ideias, com a formação de um número crescente de antropólogos indígenas, além de intelectuais indígenas de distintas áreas acadêmicas.

O objetivo desta pesquisa era mostrar como a prática da etnologia indígena está influenciada pelo meio social, cultural e político em que vivem os seus profissionais, e a crescente emergência de uma disciplina que busca tanto uma compreensão universal quanto relevância local. Temas como o papel de 'raça' versus 'cultura' em definir diferenças; ideologias 'hierárquicas' versus 'igualitárias'; e ideologias nacionais baseadas em monocultura, bi-cultura e multiculturalismo, foram examinados.

Meu interesse em estudar os estilos de etnologia indígena em países diversos começou em 1990, quando fui convidado, como mencionado, por Cardoso de Oliveira para participar do projeto de pesquisa "Estilos de Antropologia”, em que a dimensão comparativa da investigação passou a ser efetivada através do estudo do que ele decidiu chamar de "antropologias periféricas" (Cardoso de Oliveira, 1988:143-159). Cardoso de Oliveira usa este termo para referir-se àquelas antropologias situadas na periferia de centros metropolitanos da disciplina (nos centros científicos e acadêmicos onde a antropologia foi gerada e se consolidou como disciplina acadêmica - a Inglaterra, a França e os Estados Unidos da América). Frisa que a justificação maior de um enfoque estilístico sobre as antropologias periféricas está no fato de que a disciplina nos países não metropolitanos não perde seu caráter de universalidade. Cardoso de Oliveira também propôs examinar as tensões que surgem entre uma disciplina acadê- 
mica que se pretende internacional enquanto os contextos nacionais em que se pratica são específicos.

Em 1995 e 2003, realizei levantamentos de pesquisa de curta duração, semelhantes ao que havia feito na Austrália em 1992, em centros acadêmicos de etnologia indígena no Canadá, ampliando a comparação internacional, por meio de entrevistas com antropólogos que fazem pesquisas com povos indígenas naquele país, e também com alguns líderes indígenas e, em 2009-2010, passei cinco meses na University of British Columbia (UBC), Vancouver, Canadá, e seis meses na Australian National University (ANU), Camberra, Austrália, em licença de pós-doutorado.

Durante os dezoito anos, entre meu primeiro levantamento de pesquisa e a licença de pós-doutorado em 2009-2010, constatei grandes transformações na etnologia indígena nos três países focalizados. A sua expansão crescente e consolidação como campo de estudo, processos em andamento e reconfigurações orientadas por rápidas mudanças sociais, políticas e tecnológicas, trouxeram novos dilemas, novos desafios e novas perspectivas tanto para a pesquisa antropológica quanto para os papéis desempenhados por antropólogos. Aponto algumas das questões a partir de uma visão global dos múltiplos desafios enfrentados por antropólogos engajados em pesquisas com povos indígenas no Brasil, no Canadá e na Austrália, além do seu envolvimento crescente, nesses países, com questões fora da esfera acadêmica.

Parti da classificação feita por Cardoso de Oliveira (1988:143) que define o Canadá, a Austrália e o Brasil como "novas nações", ex-colônias de países europeus, apesar de terem histórias muito diferentes. Em todos esses três países a investigação sobre o "Outro" é conduzida na forma de estudos a respeito de populações indígenas (ainda que não o seja exclusivamente) sob cujos territórios os Estados nacionais se expandiram. O Canadá e a Austrália, diferentes do Brasil, foram colonizados por países que se tornaram "países de centro" da antropologia - a Inglaterra e a França. A Austrália era colônia da Grã-Bretanha, e teve territórios além-mar (Papua Nova Guiné até 1973), além de desempenhar um papel neocolonial no sudeste da Ásia, enquanto o Canadá foi colonizado pela Grã-Bretanha e pela França.

Primeiro é importante ressaltar brevemente algumas das diferenças muito óbvias na história, cultura e instituições entre o Canadá, a Austrália e o Brasil. Desde o final do século XV, expedições britânicas e francesas exploraram e, 
posteriormente, se fixaram no litoral atlântico da América do Norte. Em 1763, após a Guerra de Sete Anos, a França cedeu quase todas as suas colônias na América do Norte. O Canadá foi criado inicialmente como um domínio federal de quatro províncias, em 1867, através da Lei da Constituição, seguido logo pelo acréscimo de províncias e territórios. A Austrália se tornou uma colônia britânica em 1788, mais de 250 anos após o início da colonização portuguesa no Brasil e da colonização britânica e francesa no Canadá. Enquanto o Brasil se tornou formalmente independente de Portugal em 1822 e veio a ser uma república a partir de 1889, o Canadá apenas cortou os vestígios de dependência legal no parlamento britânico a partir do Canada Act de 1982. As seis colônias britânicas na Austrália se tornaram uma federação e foi então criada a Comunidade da Austrália em 1901. Os últimos laços entre a Austrália e a Grã-Bretanha foram encerrados com a aprovação do Australia Act de 1986, acabando com qualquer responsabilidade britânica no governo dos estados australianos.

Enquanto o Brasil foi constituído a partir de uma ideologia social hierárquica (DaMatta, 1973:1981), no Canadá e na Austrália predominaram ideologias igualitárias, ainda que coexistentes com estratificações sociais (Baines, 2003:115). Kapferer (1989:178) denomina de "nacionalismo igualitário australiano" a ideia arraigada de que a Austrália é uma "sociedade sem classes". Enquanto a Austrália e o Canadá são atualmente classificados como países "desenvolvidos" (no ranking mundial de Índice de Desenvolvimento Humano - IDH do Programa das Nações Unidas para o Desenvolvimento - PNUD a Austrália aparece em 2o lugar e o Canadá figura em 6o lugar), com altos índices de padrão de vida para grande parte de suas populações, à exceção de uma grande porção de suas populações indígenas, o Brasil está entre as nações “em desenvolvimento", com um dos maiores índices de desigualdades e injustiças sociais do mundo (estando atualmente em $73^{\circ}$ no ranking mundial de IDH do PNUD).

O Brasil possuía um grande contingente de escravos afrodescendentes desde o início de sua história colonial e foi, inicialmente, colonizado por imigrantes portugueses do sexo masculino, diferentemente da Austrália, que até os anos setenta foi colonizada predominantemente por imigrantes britânicos, e do Canadá que foi colonizado principalmente por imigrantes britânicos e franceses em seus primeiros anos de colonização.

Na primeira metade do século XX, o Canadá recebeu grandes contingentes de imigrantes europeus, seguidos por imigrantes de todas as partes do mundo 
a partir da segunda metade no século XX, transformando o Canadá em uma sociedade multicultural. Ao longo do século XIX e início do século XX, o Brasil recebeu imigrantes de várias partes do mundo, enquanto a Austrália aboliu o "White Australia Policy" ("Política da Austrália Branca") somente em 1973, abrindo o país para a imigração de não-brancos e adotando uma política multiculturalista. Entretanto, na Austrália, a suposta "cultura branca australiana" foi dividida por grandes diferenças políticas e religiosas, classe social foi uma questão significante, e a "White Australia Policy" foi manipulada muito antes da abolição dessa política para permitir a entrada de grandes contingentes de imigrantes da Europa meridional e do Oriente Médio, que não foram considerados brancos por muitos australianos.

Enquanto a Austrália mantém uma classificação racial de cor de pele dicotomista, similar àquela dos Estados Unidos, que viu a consolidação de relações sociais em castas (Rowley, 1972), baseadas em ideias racistas que opunham colonizadores brancos e populações indígenas não-brancas, denominadas blackfellas, no Brasil surgiu uma pletora de classificações raciais nas quais “a cor é vista em um contínuo de tons" (Hasenburg; Silva; Barcelos, 1992:67) e, ao longo de sua história, o Brasil apresentou discursos ambíguos de miscigenação - alguns encomiásticos, outros repudiando a miscigenação (Baines, 2003). Enquanto a população brasileira afrodescendente foi vista como parte da sociedade nacional brasileira e objeto da sociologia, as populações indígenas foram vistas como “nosso ‘outro’ que é diferente” (Peirano, 1991:167) e objeto da pesquisa antropológica. O Canadá, diferente do Brasil e também da Austrália em muitos aspectos, enfatizou a noção de "assimilação" à sociedade nacional, pensada em termos culturais e não em termos raciais, como um processo no qual se acreditava que as diferenças culturais dos povos indígenas desapareceriam.

\section{Antropologia e a ideologia de construção da nação}

Para uma abordagem comparativa sobre os estilos de antropologia, e estilos de etnologia indígena, em contextos de Estados nacionais diversos, é importante tomar em consideração, como afirma Mariza Peirano (1991), que o pensamento do antropólogo faz parte da configuração sociocultural na qual ele emerge e que a ideologia de construção da nação é um parâmetro e um sintoma importante para a caracterização das ciências sociais, onde quer que emirjam. A constatação de Bruce Kapferer (1989:166) que “a subjetividade do antropólogo, como 
aquela de qualquer pessoa, está arraigada nos mundos históricos e ideológicos nos quais ele está posicionado," reforça a afirmação de Peirano.

Chamando a atenção para a utilidade da discussão de Cardoso de Oliveira sobre as antropologias centrais versus as antropologias periféricas para problematizar as desigualdades, Gustavo Lins Ribeiro adverte sobre a necessidade de transcender tais desigualdades (Ribeiro, 2006). Inspirado pelo movimento coletivo chamado World Anthropologies Network (Redes de Antropologias do Mundo), Ribeiro afirma que esta rede busca contribuir para a articulação de uma antropologia diversificada que seja mais consciente das condições sociais, epistemológicas e políticas nas quais é produzida (Ribeiro, 2006). O autor enxerga a antropologia como uma cosmopolítica ocidental concernente às estruturas de alteridade que se consolidou como disciplina acadêmica formal no século $\mathrm{XX}$ e que tem por objetivo "ser universal, mas que, ao mesmo tempo, é altamente sensível a suas próprias limitações e à eficácia de outras cosmopolíticas” (Ribeiro, 2006:148). Como um discurso político cosmopolita, relativo à importância da diversidade para a humanidade, é parte de uma antropologia crítica da antropologia que descentraliza, re-historiciza e pluraliza a disciplina, enfatizando o papel cada vez mais importante desempenhado por antropologias não-hegemônicas na produção e na disseminação de conhecimento em escala global.

As maneiras de se pensar o Estado nacional variam bastante no Brasil, Canadá e Austrália. Trood (1990:89) afirma que "quando a Comunidade da Austrália foi fundada em 1901, seus líderes políticos não consideraram seriamente a possibilidade de se buscar uma política externa independente." Durante a primeira metade do século XX, a antropologia na Austrália deve ser vista dentro do contexto de um país em que a maioria da população via a nação como uma extensão da Grã-Bretanha, no outro lado do mundo (Baines, 1995). Depois que Radcliffe-Brown assumiu a primeira cátedra em antropologia na Universidade de Sidney em 1926, introduzindo a antropologia britânica na academia australiana e dispondo de fácil comunicação com antropólogos britânicos e norte-americanos devido à língua inglesa, o estilo de antropologia que acabou se desenvolvendo na Austrália é fortemente baseado em suas origens britânicas. Tal fato foi reforçado pelo grande número de antropólogos que trabalham na Austrália que vieram da Grã-Bretanha e dos Estados Unidos e/ou que ali concluíram seus doutorados ou pesquisas de pós-doutorado, enquanto que a maioria dos antropólogos que vivem e trabalham no Brasil são brasileiros natos. Considerando-se a história 
de relações e diálogos bastante próximos entre antropólogos britânicos, norte-americanos e australianos, vários antropólogos na Austrália sugeriram que a antropologia naquele país seria mais bem caracterizada como "semiperiférica", no sentido usado por Cardoso de Oliveira (1988) quando ele trata das "antropologias periféricas".

Se a antropologia que se faz na Austrália foi descrita por alguns antropólogos daquele país como sendo semiperiférica (Baines, 1995:75), ao discutir a antropologia no Canadá, Frank Manning (1983:2) descreveu este país como "um tipo de colônia metropolitana”, vizinha da maior superpotência do mundo. Vários antropólogos entrevistados ressaltaram a proximidade dos Estados Unidos como sendo um fator de grande importância em moldar o desenvolvimento da antropologia no Canadá e muitos antropólogos que trabalham no Canadá são de origem norte-americana ou estudaram nos Estados Unidos. Há alguma relutância por parte de muitos antropólogos em admitir a existência de um estilo canadense específico de antropologia junto a povos indígenas ou mesmo um estilo específico de antropologia, de tão forte que é a presença da antropologia norte-americana (bem como a da Grã-Bretanha e a da França, embora que em menor extensão). Alguns antropólogos, embora admitindo atualmente o caráter periférico ou semiperiférico da disciplina no Canadá, almejam uma antropologia internacional. No entanto, essa aspiração universalista na antropologia no Canadá tende a ignorar ou negar as desigualdades e assimetrias de uma situação colonial. O mesmo ocorre com uma perspectiva mais local e nacionalista, ao entrar em contradição com o ponto de vista universalista.

A antropologia no Brasil, diferentemente da disciplina no Canadá, foi desenvolvida principalmente por acadêmicos nascidos no Brasil, ainda que, até trinta anos atrás, muitos acadêmicos brasileiros iam para os Estados Unidos e outros países para realizar seus doutorados, e por uma minoria de acadêmicos de origem estrangeira, enquanto que a antropologia no Canadá, assim como na Austrália, foi estabelecida como uma disciplina acadêmica por meio da importação de antropólogos - provindos principalmente dos Estados Unidos no caso do Canadá. David Howes assinala que uma linha de pensamento argumenta que existe uma ausência de uma tradição da antropologia no Canadá, que pode ser explicada pelo fato de que "na virada do século XXI apenas 25\% do corpo docente de departamentos com doutorado em antropologia havia realizado seu doutoramento no Canadá” (2006:200). O mesmo autor apresenta a seguinte 
linha de pensamento, que pergunta:

Como poderia uma tradição local surgir em face da penetração maciça de forças externas? De acordo com Tom Dunk, esta situação é agravada pela "mentalidade essencialmente neocolonial”, que sem dúvida prevalece em Canadá de língua inglesa, onde as concepções locais do que é bom são filtradas por ideias e padrões vindos de outro lugar (Howes, 2006:200). Este ponto de vista também é ressaltado por Silverman (1991) em seu "encontro colonial na academia canadense".

\section{Antropologia francófona e anglófona no Canadá}

Ao discutir a antropologia no Canadá, julguei importante destacar as diferenças entre a antropologia no Canadá anglófono e francófono e as tensões criadas dentro da disciplina por aspirações políticas para a independência de Quebec da Federação do Canadá. A partir de Cardoso de Oliveira, constata-se que "No caso do Canadá francês, no Quebec, já vamos observar um forte processo de etnicização da disciplina, gerando, a rigor, duas modalidades de antropologia, uma francófona, outra anglófona, profundamente marcadas por seus horizontes linguístico-culturais" (1995:188).

Em entrevistas que realizei com antropólogos no leste do Canadá em 1995 (Baines, 1996) e, em 2002 (Baines, 2012), aqueles antropólogos que compartilhavam a ideologia federalista do Canadá como uma nação bilíngue (francófona e anglófona - uma ideologia que às vezes não dá ênfase aos povos aborígenes e grandes comunidades de imigrantes) expressaram seu desejo de que antropólogos francófonos e anglófonos pudessem comunicar-se como membros da nação canadense. Aqueles que apoiavam a separação de Quebec enfatizavam a precariedade da comunicação entre antropólogos anglófonos e francófonos, ressaltando os estreitos laços dos antropólogos francófonos com a antropologia dos grandes centros no nordeste dos Estados Unidos e na França e não com os antropólogos anglófonos do Canadá, tidos como seus opressores coloniais. O forte foco em Quebec, no sentido de antropologias metropolitanas, pode também contribuir para a falta de diálogo entre os antropólogos anglófonos e francófonos na província, ponto de vista ressaltado por Azzan Júnior (2004) e M. Estellie Smith (1984).

O antropólogo brasileiro-argentino Guilherme Raul Ruben (1995:125) conclui que, apesar da conflituosa questão da nacionalidade em Quebec, a teoria de identidade formulada em Quebec no âmbito da antropologia continua sendo 
“essencialmente autônoma” da questão da nacionalidade. Ruben (1995) argumenta que a antropologia em Quebec se recusa a tentar definir suas origens em relação a sua história institucional, uma vez que, de acordo com sua hipótese,

as origens dos modernos programas universitários de pesquisa e de ensino da antropologia no Quebec (nas Universidades de Montreal e de Laval) são o resultado de uma relação proibida, e eu diria até incestuosa, entre seus legítimos pais (Tremblay e Dubreuil), criadores $[\ldots]$ dos dois programas institucionais e de um outro, socialmente proibido: a antropologia americana. Num contexto nacionalista, francês, católico e rural, como poderia ser aceita a participação de um parceiro inglês, protestante e industrial, como co-genitor dos modernos programas de ensino e pesquisa em antropologia no Quebec contemporânea? (Ruben, 1995:133-134).

Na mesma obra, este autor acrescenta, "o reconhecimento dos pais fundadores dos modernos programas de antropologia no Quebec implicaria reconhecer a profunda e íntima relação da província com o mundo inglês, o que inviabilizaria o caráter étnico que marca o estilo da disciplina no Quebec" (Ruben, 1995:134).

Roberto Cardoso de Oliveira, ao abordar as singularidades de estilos da antropologia nas chamadas "periferias", afirma que não haveria de significar uma abdicação da pretensão universalista da disciplina de antropologia, "uma vez que a disciplina sempre 'falou' uma única 'linguagem', talvez mudando apenas o ‘tom'” (1998:114). Acrescenta este autor que "podemos considerar os elementos individualizantes nas antropologias periféricas que lhes conferem particularidades que [...], não nos autorizam a classifica-las com o epiteto de nacionais. Assim, não há necessidade de buscarmos nacionalizar nossas antropologias” (Cardoso de Oliveira, 1998:114).

Entretanto, a pretensão universalista da antropologia não dá conta das desigualdades e assimetrias de situações coloniais ou neocoloniais. As perspectivas mais locais e étnicas também entram em contradição com a perspectiva universalista, resultando em posturas muito diferentes, por exemplo, entre as duas maiorias de antropólogos anglófonos e francófonos no caso do Canadá.

Esses exemplos revelam as maneiras pelas quais uma complexa configuração de lealdades regionais, nacionais, imperiais, étnicas e indígenas em que os antropólogos estão imersos como membros de estados nacionais, e grupos regionais, étnicos e indígenas dentro de esses estados, permeiam suas perspectivas. 
Enquanto muitos antropólogos francófonos em Quebec sentem-se colonizados pelos canadenses anglófonos, a maioria dos canadenses francófonos e anglófonos sente-se colonizada pelos norte-americanos, e alguns antropólogos indígenas sentem-se colonizados por todos.

Cardoso de Oliveira ressalta "a inviabilidade de desassociar a aplicação da antropologia, como um modo privilegiado de conhecimento do Outro, das condições socioculturais, inclusive políticas, que propiciaram seu surgimento enquanto disciplina." (1988:149), acrescentando que "tal conhecimento ocorre num meio ideologicizado, do qual nem o antropólogo, nem a disciplina logram escapar." (Cardoso de Oliveira, 1988:149). As representações que os antropólogos fazem acerca de si mesmos surgem em diversas formas, revelando uma perspectiva de membros de Estados nacionais imperialistas, no caso dos países de centro (Stocking Jr., 1982:172) nos anos formativos da Antropologia. A situação foi parecida para os antropólogos em nações de colonização europeia que pensavam seus países como extensões dos países de centro, o que pode ser postulado para o caso da Austrália na primeira metade do século XX (Baines, 1995). Os antropólogos podem se ver como membros de Estados nacionais, ex-colônias de países europeus (nos casos do Brasil, da Austrália e do Canadá atuais, apesar das imensas diferenças), como membros de nações minoritárias que reivindicam independência do Estado (muitos dos quebequenses francófonos), e como membros de nações autóctones minoritárias dentro de Estados nacionais, alguns dos quais reivindicam autonomia limitada dentro do Estado nacional, enquanto outros aspiram a uma autonomia radical.

Merece citar Kirin Narayan (1993), antropóloga, de mãe norte-americana e de pai indiano que realizou pesquisas na Índia e que questiona a noção de "antropólogo nativo", ao abordar as ambiguidades que ela enfrentou em suas pesquisas na Índia, e propõe a sua desconstrução pelo fato que, segundo ela, tem suas raízes na situação colonial que "polariza antropólogos 'nativos' e antropólogos 'autênticos'” (1993:672). Há, também, o fato de que os antropólogos nacionais de qualquer país ou grupo étnico, ao praticar a disciplina de antropologia, estão se engajando em uma prática científica eminentemente ocidental, fato ressaltado por Gustavo Lins Ribeiro (2006) que aborda a antropologia como uma cosmopolítica. Conforme este autor, 
A antropologia, desde seu começo, é uma cosmopolítica sobre alteridade de origem ocidental. Se o reconhecimento de uma determinada afirmação em antropologia depende da sua validade, esta validade, em última instância, depende de sua consagração por uma comunidade de argumentação que é também uma comunidade cosmopolita. Até perspectivas nativistas teriam que passar por esse tipo de processo (Ribeiro, 2006:155).

Um livro útil para o estudo de estilos de antropologia, organizado por Gustavo Lins Ribeiro e Artur Escobar (2012), apresenta seu objetivo de explorar a diversidade de antropologias praticadas em vários países do mundo no início do século XXI, visando contribuir para a criação de uma comunidade transnacional de antropologia dentro de um projeto chamado "Antropologias Mundiais”. O livro e projeto que o inspirou visam transcender as dicotomias como ocidental e não ocidental, centro e periferia, hegemônico e não hegemônico, etc., para considerar os espaços comuns onde as antropologias têm se encontrado e podem se encontrar no futuro.

As críticas levantadas pelos organizadores do livro das trocas desiguais entre as antropologias visam ir além das estruturas de poder, vendo a assimetria nos termos da tensão entre o que chamam de "provincianismo metropolitano" e “cosmopolitanismo provinciano" (Ribeiro; Escobar, 2012:32). As reflexões apresentadas neste livro, apesar de serem dirigidas para a Antropologia, oferecem uma contribuição para refletir sobre estilos de etnologia indígena em contextos nacionais diversos.

João de Pina Cabral, com olhar desde Portugal, avalia a história da antropologia que se faz no Brasil como "uma história de sucesso", afirmando que,

a antropologia brasileira de nossos dias, pela qualidade da obra teórica e empírica acumulada, pela alta qualificação do seu pessoal científico, pela consolidação de suas instituições associativas e de docência, está em condições únicas para intervir ativamente no sentido de contribuir para essa tal quinta tradição, a qual, $[\ldots]$ não se sente identificada com qualquer dos projetos imperiais que, historicamente, moveram o desenvolvimento científico (Pina Cabral, 2004:263).

No mesmo artigo, Pina Cabral se refere a uma quinta tradição distinta das tradições imperiais da antropologia - que ele descreve como a francesa, inglesa, alemã e americana. 
A crescente internacionalização da antropologia que se faz no Brasil é focalizada por Gustavo Lins Ribeiro e Antônio Carlos de Souza Lima, fato que influenciou profundamente o estilo de etnologia indígena que se faz atualmente,

nossa antropologia se caracteriza por uma forte relação com a Europa, em especial com a França, com os Estados Unidos e com a América Latina. [...] A internacionalização da antropologia brasileira é um fato que deve se aprofundar também no sentido de geração de conhecimento próprio sobre realidades socioculturais, políticas e econômicas de outros países, à medida que mais e mais pesquisadores realizarem seus trabalhos de campo fora do Brasil. (Ribeiro; Lima, 2004:10).

No mesmo volume, Peter Fry ressalta que o fortalecimento dos laços com mais "comunidades antropológicas" pode enriquecer a antropologia que se faz no Brasil além da "forte e tradicional relação da antropologia brasileira com os antigos centros de difusão da disciplina” (Fry, 2004:244).

No Brasil, vários trabalhos que refletem sobre a etnologia indígena, como os trabalhos bibliográficos de Julio Cezar Melatti (1982; 1984), Anthony Seeger e Eduardo Viveiros de Castro (1980); uma resenha mais recente da etnologia americanista intitulada "Etnologia brasileira" de Viveiros de Castro (1999), várias publicações sobre indigenismo por Alcida Ramos (1998) e uma reflexão sobre o estilo brasileiro de fazer etnologia (Ramos, 1990), um levantamento sobre etnologia indígena de autoria de Roque de Barros Laraia (1987), publicações sobre política indigenista por Roberto Cardoso de Oliveira (1978), João Pacheco de Oliveira (1998; 1999), Antônio Carlos de Souza Lima (1995) e muitos outros antropólogos que vêm escrevendo no âmbito da tradição estabelecida na etnologia indígena no Brasil que focaliza as relações interétnicas desses povos dentro do contexto do estado nacional, sem desprezar o estudo sobre os aspectos internos das sociedades indígenas, tradição firmemente estabelecida por Darcy Ribeiro, e que tem como seu principal mentor teórico Cardoso de Oliveira em sua noção de "fricção interétnica" no início dos anos 1960.

Cardoso de Oliveira, influenciado pelo estudo das relações sociais da antropologia britânica na época, e a noção de "situação colonial" de Georges Balandier, mudou o foco em etnologia no Brasil de estudos de aculturação, influenciados na época principalmente pela antropologia norte-americana, para as relações sociais do contato interétnico entre os povos indígenas e segmentos 
da sociedade nacional, bem como a natureza conflituosa e contraditória destas relações (Cardoso de Oliveira, 1981 [1964], 1978).

Mariza Peirano sugere que,

o conceito de 'fricção interétnica' foi ele próprio o resultado teórico da dificuldade e/ou da impossibilidade de se viver a distinção (entre 'antropologia das populações nativas' e 'antropologia da sociedade nacional') por antropólogos brasileiros, constituindo-se, talvez, no conceito mais genuinamente 'nativo' que a antropologia já produziu no Brasil (1991:83-84).

Peirano também argumenta que:

No Brasil, uma teoria de engajamento político levou ao desenvolvimento do conceito de 'fricção interétnica' [...]. O conceito de fricção interétnica [...] teve como objetivo uma avaliação do potencial de integração dos grupos indígenas na sociedade nacional juntamente com uma preocupação teórica, em que o engajamento político do antropólogo era incontestável (1992:247-248).

A noção de "fricção interétnica" influenciou profundamente o desenvolvimento do estilo de etnologia indígena praticado no Brasil, inspirando praticamente toda a produção acadêmica a partir do início dos anos 1960 até meados dos anos 1980. A partir do final dos anos 1980, João Pacheco de Oliveira Filho, do Museu Nacional, UFRJ, elaborando a partir do trabalho de Cardoso de Oliveira e sob a influência de Max Gluckman e a Escola de Manchester, apresentou a noção de "situação histórica", que se refere a "modelos ou esquemas de distribuição de poder entre diversos atores sociais” (Oliveira Filho, 1988:57). Trabalhos mais recentes deste autor e de seus estudantes de doutorado refletem sobre o fenômeno da reelaboração cultural no nordeste do Brasil (Oliveira Filho, 2004).

Outra linha de pesquisa em etnologia indígena foi desenvolvida, também, no Museu Nacional, UFRJ, em torno de Eduardo Viveiros de Castro $(1996,2011)$ e alguns de seus doutorandos, sobre o "perspectivismo" ameríndio, ou seja, as ideias, presentes nas cosmologias dos indígenas amazônicos a respeito do modo como humanos, animais e espíritos veem-se a si mesmos e aos outros seres do mundo.

No Brasil, uma série de publicações examina os estilos de antropologia em diferentes contextos nacionais, como, por exemplo, os trabalhos de Cardoso de Oliveira $(1988,1998)$ em que propõe o estudo das antropologias periféri- 
cas; a pesquisa de Cardoso de Oliveira sobre etnicidade como fator de estilo na antropologia da Catalunha (1998); Mariza Peirano (1981; 1992; 1995) em trabalhos sobre Brasil e Índia; Leonardo Fígoli sobre a Argentina (1995); e Guilherme Ruben (1995), Celso Azzan Júnior (2004) e, mais recentemente, Cristhian Teófilo da Silva $(2008 ; 2014)$ sobre Quebec, Canadá. Estes e muitos outros trabalhos representam tentativas, algumas de natureza comparativa, de se pensar a disciplina em termos antropológicos.

\section{O lugar de Etnologia Indígena na Antropologia}

No Brasil, Canadá e Austrália, a antropologia foi inicialmente introduzida em museus e, quando se estabeleceu como disciplina acadêmica, foi, em princípio, definida como o estudo dos povos indígenas. Apesar do fato de que a antropologia social no Brasil, Canadá e Austrália logo tenha expandido seus objetos de estudo para incluir outras áreas além do estudo de povos indígenas, nos três países a etnologia com povos indígenas ainda desempenha um papel central (Berndt e Tonkinson, 1988; Dyck, 1990; Melatti, 1984; Viveiros de Castro, 1999). No entanto, no Canadá e na Austrália, desde o início de sua história como uma disciplina acadêmica, a antropologia social foi dividida pelos antropólogos que lá trabalham em áreas geográficas em nível mundial, como nas tradições britânica, francesa e norte-americana, diferentemente da antropologia que se fazia no Brasil até o final da década de 1980, que, com raras exceções, era restrita ao Brasil. Somente a partir do início da década de 1990, a antropologia no Brasil se expandiu de modo a incluir a pesquisa em áreas geográficas em nível mundial.

Em um breve panorama da antropologia no Canadá, Noel Dyck (1990) classifica a maior parte das publicações de antropologia social e cultural escritas durante os anos 1970 e 1980 utilizando um ou mais dos quatro títulos: "etno-história, etnologia, estudos de comunidades, e o estudo das relações entre os povos nativos e o estado" (Dyck, 1990:43). Tanto Dyck quanto Kew observam, até a década de 1990, uma escassez de pesquisas antropológicas sobre a situação dos povos indígenas em áreas urbanas (Dyck, 1990; Kew, 1993-1994), apesar do fato de que na província de Colúmbia Britânica, por exemplo, em 1989, quase a metade dos indígenas cadastrados como "Status Indians” residia fora das Reservas Indígenas. Esta situação mudou ao longo dos últimos vinte anos com muitos projetos de pesquisa recentes sobre os povos indígenas em áreas urbanas. $\mathrm{Na}$ década de 1970, a atenção dos etnólogos mudou-se de comunidades mais iso- 
ladas para o estudo de índios aculturados, índios urbanizados, grupos minoritários, frações ou seções étnicas etc., o que marca um desenvolvimento, de certa forma semelhante ao observado por Peirano (1991) na antropologia que se faz no Brasil. A partir de um primeiro foco sobre os povos aborígenes, houve uma mudança para outros temas, tais como minorias étnicas dentro da sociedade nacional, e depois para a sociedade canadense em si, bem como uma preocupação com questões políticas e estudos de análise do discurso (Drummond, 1983; Paine, 1983). Uma coleção mais recente de artigos no volume editado por Harrison e Darnell (2006a) examina de maneira mais detalhada o desenvolvimento histórico da antropologia no Canadá.

Noel Dyck, refletindo sobre as recentes mudanças na antropologia no Canadá e na etnografia de "administração indigenista", afirma que:

nas fases finais de uma era de política de identidade, foi tomado um cuidado considerável na preparação de antropólogos não tanto como intelectuais, e sim como profissionais com uma orientação prática com o intuito de divulgar sua simpatia e solidariedade com os povos indígenas e de colocar seus serviços à disposição dos líderes aborígenes (2006:87).

Hamilton (1982) apresenta um breve panorama da antropologia na Austrália até o início dos anos 1980, assim como McCall (1982). Ronald Berndt e Robert Tonkinson, ao examinar o desenvolvimento da antropologia social e estudos sobre povos indígenas no período de 1961 a 1986, ressaltam a importância da pesquisa em etnologia indígena na Austrália (Berndt; Tonkinson, 1988:6). Estes autores dividem seu livro em cinco tópicos: gênero, parentesco, economia, direito e religião, que, com a exceção de "gênero", seguem a divisão tradicional de uma monografia na antropologia britânica, revelando a forte influência da tradição britânica. Eles observam, contudo, que a "antropologia de resgate", que prevaleceu até 1961, deu lugar ao estudo dos processos de mudança e transformação cultural (1988:4).

A maioria dos antropólogos entrevistados em 1992 afirmou que a construção da nação não se apresentou como uma questão relevante na antropologia que se faz na Austrália (Baines, 1995). Na opinião de um antropólogo norte-americano que trabalha na Austrália, a questão da construção da nação não está presente no pensamento da maioria dos antropólogos que trabalham naquele país. No entanto, este mesmo antropólogo argumenta que a questão da tensão entre 
os povos indígenas e a sociedade nacional estava em primeiro plano, uma forma diferente de reconhecer um problema similar. O mesmo antropólogo menciona, em contraste, a antropologia que se faz na Indonésia como um exemplo de um estilo de antropologia estreitamente relacionado com a questão de integração nacional e a tentativa de se criar uma identidade nacional, em que alguns antropólogos, como, por exemplo, Koentjaraningrat, identificaram-se com questões nacionais, examinando-as por meio de uma teoria da etnicidade e um foco sobre a questão de uma identidade indonésia. A situação, no entanto, difere muito da do Brasil, considerando que a Indonésia é um estado nacional muito mais novo que o Brasil, formado por um enorme arquipélago de muitas ilhas e dividido por grandes contingentes de grupos étnicos com amplas diferenças culturais e linguísticas, que foi colônia holandesa até 1949. Além disso, sendo uma ex-colônia em que a maioria dos povos colonizados foi dominada por uma minoria de colonizadores europeus durante a ocupação holandesa, diferentemente da Austrália, que foi concebida como uma nação de colonização por colonos europeus, a Indonésia enfrentou e ainda enfrenta o problema de tentar construir um estado nacional como um programa político (Geertz, 1973).

Uma importante mudança na etnologia indígena ocorreu na antropologia anglófona no Canadá durante os anos 1960 e início da década de 1970, com a ocupação intensiva do norte do continente e estudos dirigidos para questões de desenvolvimento e modernização, similar ao que ocorreu também na Austrália, com o desenvolvimento em larga escala de projetos de mineração no norte e centro do continente, e no Brasil, com a implantação de projetos de desenvolvimento de grande escala de mineração, hidrelétricas, criação de gado e um sistema de rodovias na Amazônia brasileira, a partir da década de 1970. Estes estudos estavam diretamente relacionados à construção da nação canadense, mas foram vistos pelos antropólogos envolvidos não tanto como uma questão de construção da nação, e sim como uma questão de lidar com problemas específicos como especialistas ou tecnocratas.

Na Austrália, após a Segunda Guerra Mundial, Peterson (1990) percebe uma transformação fundamental na antropologia. A ameaça de uma invasão japonesa a partir do norte induziu o governo a melhorar a rede de comunicação interna e a ocupar definitivamente o norte do continente, especialmente no Território do Norte. Neste período, ainda que houvesse cerca de mil indígenas que não haviam tido contatos com os europeus "parece que houve uma visão acadêmica 
generalizada, dentro e fora da Austrália, de que as sociedades e culturas aborígenes já não podiam oferecer um insight especial” (Peterson, 1990:14). Com a ocupação completa do norte do continente, os indígenas australianos passaram a ser pensados como "nossos outros" e, portanto, menos exóticos do que os "outros" além dos mares (Baines, 1995). Peterson, citando Cowlishaw, assinala que

uma consequência disso foi que realizar pesquisas com povos indígenas era pensado como "fazer antropologia em casa", enquanto, antes desse período, realizar pesquisas junto a populações aborígines no norte da Austrália era considerado como se fosse pesquisar além dos mares. Os estilos de vida não-ocidentais interessantes e autênticos passaram a ser encontrados exclusivamente fora da Austrália e as pesquisas realizadas na Austrália tornaram-se menos valorizadas profissionalmente (1990:14).

Tal fato fornece um claro contraste com a etnologia indígena no Brasil naquele período em que as sociedades indígenas em território nacional eram objetos privilegiados de estudo. No caso da Austrália, uma nação de colonização europeia, conceituada na época como uma extensão antípoda da Grã-Bretanha, proponho que não houvesse a possibilidade de admitir uma administração indireta das populações nativas e, consequentemente, a teoria funcionalista não era pensada como adequada para estudá-las. Naquele período, as populações nativas eram excluídas da história e do futuro da nação australiana, perdendo seu caráter "exótico".

A partir do final da década de 1960 e a década de 1970, o trabalho de Otávio Velho abriu uma nova perspectiva na antropologia no Brasil, com foco de análise sobre o estado nacional (Peirano, 1991) e "apesar de todos os esforços para incorporar o tema indígena na disciplina, o indígena permaneceu como o 'outro' que é 'diferente”' (Peirano, 1991:167).

A premissa da homogeneidade, que é uma das doutrinas básicas do processo de construção da nação brasileira, não alcançou os indígenas, e, porque eles não poderiam ser incorporados como parte de um "nós" nacional, eles foram excluídos, mantendo o papel do 'outro diferente' (Peirano, 1991:168).

Acrescenta Peirano que "apesar do fato de que o indígena não é mais considerado por todos os antropólogos como objeto verdadeiro e genuíno de análise 
da disciplina, a preocupação com os indígenas não desapareceu" e que "fazia parte de seu papel de 'intelectuais' a preocupação dos antropólogos com as populações indígenas” (Peirano, 1991:169). A autora afirma que os antropólogos, como cidadãos brasileiros, "são responsáveis pelos direitos das populações que estudam [...] os antropólogos brasileiros que estudam os indígenas estão olhando para parte da população do seu próprio país...” (Peirano, 1991:101).

$\mathrm{Na}$ década de 1950, a antropologia nos três países foi definida em grande parte como o estudo das populações nativas, embora, no Canadá e na Austrália, diferentemente do Brasil, esta definição tenha incluído não somente as populações indígenas internas, mas também os povos nativos de outros países do mundo. No caso da Austrália, a disciplina incluía a Oceania e o Sudeste da Ásia, e, sobretudo, a Nova Guiné - que era, à época, uma colônia australiana. No caso do Canadá, o campo da pesquisa antropológica abrangia o mundo, dividido em continentes e em áreas de pesquisa como na antropologia norte-americana. Entretanto, conforme mencionam Harrison e Darnell,

até que os currículos universitários começassem a se expandir na década de 1960 e 1970, à medida que os antropólogos canadenses se aventuravam para além de suas fronteiras nacionais, a antropologia seguiu a tradição americanista de estudo quase exclusivo dos povos indígenas da nação (2006b:8).

De acordo com Peirano, referindo-se ao período formativo da antropologia no Brasil, “o antropólogo no Brasil faz parte de uma elite que se define como o grupo 'intelectual' do país” (1991:174). A autora acrescenta que os acadêmicos são definidos como "intelectuais” e que "intrínseca a esta definição está uma abordagem crítica à sociedade brasileira”. Peirano (1991) também afirma que no Brasil há uma noção que, por escrever, o antropólogo como um intelectual é um cidadão engajado que está contribuindo para a construção da nação. Peirano mostra que essa ideia, que "contrasta com a do intelectual europeu [...] que não enfatiza tanto o compromisso com questões nacionais” (1991:174), era parte da vida intelectual brasileira, embora nem sempre fosse consciente no pensamento dos antropólogos brasileiros. Como mencionado acima, naquele momento, havia no Canadá uma forte tradição norte-americana com influências britânicas e francesas e, na Austrália, uma tradição antropológica em grande parte britânica, não havendo uma identificação consciente do antropólogo com um papel de construção da nação - a questão nacional veio a ocupar um lugar de desta- 
que na vida intelectual da Austrália na década de 1970 (Peterson, 1990:16), e de uma forma muito diferente da ideologia de construção da nação para a qual Peirano e Ramos (1990) chamam a atenção no caso do Brasil.

Em Quebec, no entanto, conforme menciona Asen Balikci (1980:124) "Os quebequenses foram estudar os ameríndios de Quebec. Os seus ameríndios, na sua província. A história dos ameríndios fazia parte da história deles”, relacionando a antropologia diretamente ao processo de construção da nação. A ideologia de construção da nação em Quebec, com a qual muitos antropólogos identificam como quebequenses, entra em conflito com o seu compromisso ético para com os interesses dos indígenas.

\section{Tendências recentes na Etnologia Indígena}

Observa Alcida Ramos que a "profunda transformação no papel político dos índios, a nível local e nacional” (1990:466) dos movimentos políticos indígenas no Brasil (onde as populações indígenas constituíam na época uma minoria de apenas $0,2 \%$ da população nacional), levou a uma situação cada vez mais complexa, em que "nenhuma das abordagens teóricas conhecidas - estudos de aculturação, fricção interétnica, ou etnicidade, por exemplo - parecia adequada para desvendar" (1990:466). A inadequação de uma antropologia com base no 'abismo sujeito-objeto' levou a uma abordagem dialógica, como também ocorreu com a etnologia indígena no Canadá e na Austrália durante as últimas décadas. Três exemplos que visam abordar teoricamente a questão das relações interétnicas na Austrália: os estudos de Barry Morris (1991), que utilizam a noção de resistência ao escrever sobre uma população indígena no estado de New South Wales, no sudeste da Austrália, o trabalho de David Trigger (1992), que usa as noções de acomodação e resistência ao descrever a vida de um povo indígena em uma missão no norte de Queensland, e as pesquisas de Francesca Merlan (1998), que reexaminam os estudos antropológicos sobre as relações entre mudança e continuidade nas sociedades indígenas a partir de uma análise das práticas dos povos indígenas, focando a situação intercultural vivida por indígenas em uma cidade do Northern Territory.

Embora não exista, em nenhum dos três países, um consenso sobre a definição de um estilo de etnologia indígena, vários antropólogos caracterizaram grande parte da pesquisa etnológica realizada na Austrália como tendo uma forte ênfase no estudo empírico de fatos sociológicos, econômicos, políticos e 
religiosos, seguindo a tradição britânica - além de uma forte ênfase na realização de longos períodos de pesquisa de campo que resultaram em monografias de estilo descritivo. Isto contrasta com a etnologia indígena no Brasil, com sua ênfase em valores, refletindo a influência francesa e uma definição diferente da própria antropologia que "nasceu de uma tradição comum a filósofos, escritores e outros humanistas, conforme assinala Peirano” (Ramos, 1990:456). Enquanto no Brasil, a antropologia social surgiu das ciências sociais e se consolidou mais tarde como uma disciplina acadêmica distinta, na Austrália, a antropologia social foi introduzida como disciplina acadêmica já consolidada por Radcliffe-Brown, em 1926. Antropólogos, herdeiros da tradição britânica, dirigiram sua atenção para os temas de organização social e parentesco. A sociologia, em contraste, foi introduzida muito mais recentemente na Austrália, como uma disciplina distinta. No entanto, a diversificação da antropologia social na Austrália, especialmente desde os anos 1980, tem modificado profundamente este estilo.

Vale ressaltar que, no Brasil, embora a questão do racismo tenha sido examinada tanto pela antropologia quanto pela sociologia, foi abordada, sobretudo, em estudos de 'relações raciais' associados com os afro-brasileiros e menos na etnologia indígena, que foi associada com a noção de cultura em 'estudos de aculturação' .

Nos últimos vinte e cinco anos, a rápida expansão dos programas de doutorado em universidades dos três países levou à formação de um número suficiente de profissionais com doutorado em antropologia para perpetuar a disciplina sem a necessidade de importar acadêmicos e sem a necessidade de os alunos realizarem sua pós-graduação no exterior, como foi o caso em períodos anteriores. Nos três países tem havido um crescente envolvimento de antropólogos em experiências de intervenção social durante este mesmo período, incluindo a participação em processos de reivindicação territorial, relatórios de impacto socioambiental para grandes projetos de desenvolvimento, trabalhos de consultoria para organizações governamentais e não-governamentais, tais como a Fundação Nacional do Índio (FUNAI), o Ministério Público Federal (MPF), o Instituto Socioambiental (ISA), o Centro de Trabalho Indigenista (CTI), no Brasil.

No Canadá e na Austrália muitos antropólogos realizam consultorias para comunidades indígenas, organizações governamentais e não-governamentais e para o setor de mineração. Este envolvimento social levou a antropologia a dilemas, ao mesmo tempo em que tem contribuído para o fortalecimento 
da pesquisa com povos indígenas. Os desafios enfrentados pelos antropólogos levaram ao surgimento de novas questões e desenvolvimentos teóricos, com novas pesquisas colaborativas e participativas, ampliando os horizontes da antropologia como disciplina acadêmica, tais como a demarcação participativa de terras indígenas (Oliveira Filho; Iglesias, 2002). O antigo papel do antropólogo como intermediário e porta-voz entre os povos indígenas e o Estado foi substituído pelo de um assessor, que estabelece uma postura dialógica de compromisso político com os povos indígenas com quem trabalha, respeitando suas opiniões e decisões (Oliveira Filho, 2009).

Há, também, um esforço crescente entre os indígenas envolvidos em movimentos políticos indígenas nos três países em disc ussão a se profissionalizarem e, desta maneira, enfrentar as sociedades nacionais usando suas ferramentas para tentar efetivar os seus direitos indígenas. No Brasil, a demanda dos povos indígenas para terem acesso à educação é mais recente do que no Canadá e na Austrália e, ao longo dos últimos dez anos, essa demanda cresceu muito rapidamente (Baniwa, 2009). Muitas lideranças indígenas que participam da administração de organizações indígenas são profissionais altamente qualificados e alguns são antropólogos. Ramos (2010) argumenta que, apesar da grande mudança no papel político dos indígenas ao longo dos últimos quarenta anos, a consolidação de relações simétricas em pesquisas etnológicas só será alcançada "quando as ideais acadêmicas e as indígenas se fertilizarem mutuamente, gerando novas compreensões de parte a parte" (Ramos, 2010:41).

\section{Publicações recentes em Etnologia Indígena: Canadá e Austrália}

Cito apenas algumas das numerosas publicações recentes que refletem a diversificação da pesquisa antropológica no Canadá e na Austrália atualmente. Na Austrália, Yasmine Musharbash (2008) examina a vida cotidiana em uma comunidade indígena na Austrália central, apresentando retratos narrativos de cinco mulheres da etnia Warlpiri e as maneiras pelas quais pessoas que vivem em uma comunidade relativamente remota relacionam-se com o Estado. A partir de uma perspectiva histórica e antropológica, Howard Morphy (2007) analisa os contextos de mudança cultural e social que envolvem a produção de arte indígena Yolngu na Austrália. Diane Austin-Broos (2009) estuda dois momentos de mudança no mundo do povo Western Arrernte: a política de sedentarização imposta no final do século XIX, e o movimento de 'regresso ao território tra- 
dicional' patrocinado pelo Estado que acompanhou a política de autodeterminação do governo federal na segunda metade do século XX. Gillian Cowlishaw (2004) examina as relações raciais a partir de uma análise da interface do multiculturalismo australiano e da situação dos povos indígenas na área rural do estado de New South Wales.

Uma coleção de artigos críticos foi organizada por Jon Altman e Melinda Hinkson (2007) em resposta à intervenção do governo federal australiano na vida de mais de 40.000 indígenas do Território do Norte em 2007, sob o pretexto de uma emergência nacional em relação às alegações amplas de abuso sexual de menores de idade. Conforme afirma Hinkson, tais medidas restritivas para impor controle sobre os povos indígenas por parte do Estado "constituem uma intervenção governamental sem precedentes em política indigenista nos últimos quarenta anos" (Hinkson, 2007:1). Altman assinala que "Este plano radical que visa à transformação de sociedades organizadas em princípios de parentesco em sociedades organizadas em torno do mercado é baseado em noções altamente controversas [...]" (Altman, 2007:307). Os ensaios indicam que os motivos reais do governo federal eram de se aproveitar deste relatório sobre o abuso sexual de crianças indígenas para impor políticas de integração acelerada aos povos indígenas, em tentativa de forçar os indígenas a entrar na economia capitalista de mercado.

Uma publicação recente que teve forte impacto na etnologia indígena que se faz na Austrália é a coleção de ensaios altamente polêmicos, publicada em 2009, pelo antropólogo linguista Peter Sutton, chamada The Politics of Suffering: Indigenous Australia and the end of the liberal consensus. Neste livro, Sutton afirma ter quebrado o silêncio de alguns antropólogos que, juntamente com a esquerda política, têm apoiado, desde a década de 1970, o movimento que visava à descolonização dos povos indígenas na Austrália. O autor defende abertamente as intervenções do governo no Território do Norte sob o pretexto de que é impossível permanecer em silêncio ante a trágica situação em que se encontram muitas comunidades indígenas e que as medidas governamentais eram necessárias para salvar estas comunidades indígenas de "descent into dysfunction” (entrarem em uma situação de colapso total) (Sutton, 2009:3). Este autor também descreve o povo indígena Wik, em Aurukun, na Península de Cape York, com quem realizou pesquisas de campo a partir da década de 1970, e mais tarde participou de projetos de pesquisa de assistência comunitária, além de ter 
atuado como principal pesquisador na reivindicação territorial desse povo indígena. Segundo Sutton, "Os níveis de conflitos violentos, de estupros, agressões a crianças e a idosos e de negligência tinham aumentado de forma alarmante desde a introdução do fornecimento regular de álcool em 1985” (2009:1).

Sentindo-se impotente para influenciar a política do Estado, Sutton ataca veementemente seus colegas antropólogos por terem permanecido em silêncio e, ao mesmo tempo, busca explicar a situação de violência em comunidades indígenas a partir de traços culturais tradicionais e, então, justifica a política intervencionista agressiva do governo. O livro de Sutton provocou profundas críticas e resultou em uma divisão entre aqueles antropólogos e lideranças indígenas que discordaram fortemente da intervenção federal no Northern Territory em 2007, outros, assim como Sutton, que simpatizaram com a intervenção como uma medida necessária para mudar as péssimas condições em algumas comunidades indígenas, e ainda outros que aceitaram alguma forma de intervenção do governo, mas são altamente críticos à maneira que ela foi feita.

No Canadá, as publicações de Bruce Miller (2000) examinam a tradição e a lei no mundo dos povos Salish do litoral da província de British Columbia, e a política de não-reconhecimento dos povos indígenas por parte dos Estados nacionais (2003), focando principalmente os Estados Unidos e o Canadá. O mesmo autor organizou uma coletânea de ensaios que inclui artigos escritos por líderes indígenas (2007) e um livro sobre a história oral dos indígenas nos tribunais (2011).

Uma publicação organizada por Mario Blaser, Harvey Feit e Glenn McRae (2004) reúne artigos que analisam os impactos de grandes projetos de desenvolvimento no Canadá e em todo o mundo. A história da pesca nativa na província de British Columbia e as proibições coloniais para a pesca do salmão, além da incapacidade de reconhecer bases jurídicas indígenas alternativas são examinadas por Douglas Harris (2001), e uma publicação de Jennifer Kramer (2006) examina a maneira como os povos Nuxalk de British Columbia negociam questões como "A quem pertence a cultura?", "Como deve ser a cultura transmitida às gerações futuras?”, "Onde se encaixa a compra e venda de arte Nuxalk na tentativa de recuperação do controle do patrimônio?”. Esta autora analisa as formas que os povos Nuxalk utilizam seu patrimônio cultural para afirmar sua identidade coletiva nacional em sua tentativa de recuperar a autodeterminação na província de British Columbia. 
O estilo da antropologia praticado no Canadá surgiu, sobretudo, sob a influência da antropologia que se faz nos Estados Unidos, mas também foi influenciado pelos estilos de antropologia britânica e francesa, facilitado pelos idiomas inglês e francês e pelo intercâmbio acadêmico entre esses países e, mais recentemente, entre o Canadá e a Austrália. Esses fatores reforçam que seja caracterizada como sendo "semiperiférica", segundo a opinião de muitos antropólogos que trabalham no Canadá, no mesmo sentido das "antropologias periféricas" usado por Cardoso de Oliveira (1988). Um fator que explica o caráter dinâmico da antropologia que se faz no Canadá tem sido apontado pela antropóloga canadense Marilyn Silverman, que em seu artigo sobre o encontro colonial na antropologia do Canadá, conclui que, "Certamente não pode ser por acaso que os antropólogos canadenses, na periferia de um império, estejam preocupados com a trajetória político-econômica do poder e da exploração em suas várias formas" (1991:392).

A antropóloga, Vered Amit, afirma que "em termos da reprodução da antropologia como disciplina acadêmica no Canadá, o problema pode ser não tanto que somos periféricos, mas que não somos periféricos o suficiente" (2006:267). A influência desmedida dos Estados Unidos da América sobre a antropologia que se faz no Canadá é descrita por Marilyn Silverman no que ela chama de "encontro colonial na academia canadense" (1991), que se tornou evidente durante um processo de seleção de professor por concurso público, do qual ela participou. Silverman descreve a situação em que a "metáfora central era 'canadense [incompetente] versus americano [competente]'” (1991:388) e como os candidatos canadenses foram imediatamente descartados, pois os membros da banca iniciaram seu discurso, "com a premissa do colonizado: que canadense é inferior. Nosso objetivo é de contratar alguém que demonstra excelência acadêmica. Por definição, tal candidato não poderia ser um de nós, inferiores. De onde deve vir tal candidato? É claro, de nossos superiores, do outro colonizador, dos Estados Unidos" (1991:391).

Esta pesquisa sobre três estilos de etnologia indígena - Brasil, Canadá e Austrália - revela diferenças notáveis, sobretudo aquelas que resultam de histórias e estilos de colonização muito diferentes entre três poderes europeus - Portugal, Grã-Bretanha e França. Obviamente, as histórias e as diferenças locais são muito complexas para serem abordadas neste Memorial e é inevitável que aconteça um achatamento de nuance ao lidar com questões tão amplas. Porém, apesar da 
enorme diversidade cultural e histórica, as situações coloniais compartilhadas por Brasil, Canadá e Austrália apresentam algumas semelhanças surpreendentes que estão se tornando cada vez mais evidentes na medida em que as fronteiras nacionais da antropologia se tornam menos rígidas e os movimentos políticos indígenas estão se internacionalizando, recorrendo às leis internacionais para pressionarem os Estados nacionais a efetivar os direitos indígenas.

Ao longo dos últimos vinte anos, os movimentos políticos indígenas tornaram-se cada vez mais sofisticados e globalizados na sua organização, o que transformou a pesquisa antropológica em uma tarefa mais complexa e, ao mesmo tempo, mais dinâmica, na medida em que pesquisadores em etnologia, indígenas e não indígenas, trabalham junto com intelectuais indígenas de diversas áreas acadêmicas. As desigualdades do passado colonial entre antropólogos e os povos indígenas pesquisados foram substituídas por acordos entre antropólogos e esses povos para realizar pesquisas em igualdade de condições, em que o antropólogo tem de respeitar as demandas e os interesses dos povos indígenas em pesquisas colaborativas e participativas, frequentemente compartilhando o campo com antropólogos indígenas dos mesmos povos com que se realiza pesquisa. Situações em que antropólogos se engajam cada vez mais em intervenções governamentais e projetos de desenvolvimento nacionais e internacionais que resultam de processos econômicos e políticos globais, como também as tentativas por parte de grandes consórcios de empresas de privatizar políticas indigenistas, levantam várias perguntas que muitas vezes conduzem a divergências de opiniões entre os antropólogos sobre questões políticas que não têm respostas simples. Divergências de opiniões semelhantes se encontram nas posições múltiplas defendidas por lideranças indígenas e suas organizações em um mundo cada vez mais complexo.

Entre os trabalhos mais recentes publicados que exploram temas nesta linha de pesquisa, incluem:

- "Politiques indigénistes au Brasil, au Canada et en Australie - Les défits de la pratique anthropologique dans divers contextes nationaux". Recherches Amérindiennes au Québec, v. XLIV, p. 5 - 12, 2015;

- "Social Anthropology with Indigenous Peoples in Brazil, Canada and Australia - a comparative approach”. Vibrant (Florianópolis), v.9, p. 209 - 238, 2012.

Além de dar continuidade à pesquisa comparativa sobre os estilos de etnolo- 
gia indígena no Brasil, na Austrália e no Canadá, estou planejando também realizar/coordenar, com a participação de alunos de doutorado do PPGAS/DAN/ UnB, estágios de pesquisa na Argentina, no Japão e na China, e outros países nos próximos anos, como casos de comparação, e/ou incentivar futuros alunos de doutorado a realizar estas pesquisas.

Desde o segundo semestre de 2016, a partir de um estágio de pesquisa de três meses, realizada em licença de capacitação, na Universidade de Buenos Aires (UBA), a comparação está sendo ampliada para incluir a etnologia indígena que se faz na Argentina, para abranger países de colonização britânica (Austrália), britânica e francesa (Canadá), e dois países da América do Sul (Brasil e Argentina) de colonização portuguesa e espanhola respectivamente, todos esses quatro países com histórias e culturas muito distintas. Os estilos de antropologia no Japão e na China encaixam-se no tipo de sociedade que Cardoso de Oliveira caracteriza como "as antigas nações asiáticas, possuidoras de fortes e profundas tradições culturais letradas” (1988:149). No caso do Japão, pretende-se examinar as pesquisas realizadas junto aos povos que se autoidentificam como autóctones - os Ainu da Ilha de Hokkaido, e o povo das Ilhas Okinawa, situadas no sul do Japão para investigar como a antropologia que se faz no Japão lida com a questão de etnicidade dentro do Estado nacional japonês, Estado conceituado na ideologia nacional como etnicamente homogêneo (Shigeru, 1994 [1980]; Ishii, 2000). Pretende-se realizar entrevistas em inglês com antropólogos no Japão e com acadêmicos Ainu. Cabe examinar fenômenos como o declínio de pesquisas junto aos Ainu em Antropologia Social/Cultural ao longo dos últimos 40 anos e certa apatia atual nesses estudos, observada por vários antropólogos japoneses, ao mesmo tempo em que os Ainu se apropriaram do conceito de cultura para fazer valer seus direitos em uma nação que ressaltava a homogeneidade étnica como ideologia nacional.

Mantenho contatos com o Professor Takeo Funabiki, colega do Programa de Pós-Graduação em Antropologia Social da Universidade de Cambridge (197980 ) onde cursei o mestrado em antropologia social. Takeo Funabiki é, atualmente, professor de antropologia cultural na Universidade de Tóquio e me apresentou a vários acadêmicos que realizam pesquisas em Estudos Ainu, como Shuwa Honda (Showa Universidade, Tóquio), que escreveu vários comentários comparativos em japonês sobre a situação dos Ainu comparada com povos indígenas em ex-colônias britânicas, e se dispõe a colaborar comigo em entrevistas 
sobre o assunto no Japão. Outros contatos são:Yoshinobu Kotani (Nanzan University) que trabalha com coleções Ainu em museus; Kazujoshi Otsuka, (National Museum of Ethnology - Minpaku); Saito Reiko (curador do Museum of Northern Peoples and Cultures - Abashiri) que realiza pesquisa sobre turismo entre os Ainu; Nakagawa Hiroshi (Chiba University); Okuda Osami (Sapporo Gakuin University); Tsunemoto Teruki (Direito, Hokkaido University) que realiza pesquisa sobre legislação Ainu; Sasaki Toshikazu (Tokyo National Museum), especialista em arte Ainu; Motomichi Kono (Hokkaido University); e Takashi Kinase (Universidade de Tóquio).

Após a visita ao DAN/UnB, em novembro de 2012, de uma delegação de pesquisadores da China, Dr. Wang Yanzhong, Diretor do Institute of Ethnology and Anthropology, Chinese Academy of Social Sciences, Beijing; Dr. Wu Jiaduo, editor; Dra. Liu Zhen, diretora de programas; e Dr. Zhu Lun, Vice-Presidente da Chinese Association of Ethnic Studies, fui apresentado ao professor Zhang Jijiao, Diretor do Departamenro de Pesquisa Social do mesmo Instituto, com quem venho me comunicando para planejar uma visita técnica de pesquisa na China para estudar a Antropologia Social que trabalha com povos minoritários naquele país, e tentar me inserir em algum evento científico na China, junto com pesquisadores que estudam povos minoritários.

A linha de pesquisa sobre estilos de etnologia indígena pretende contribuir para o processo de internacionalização da Antropologia e faz parte de um plano maior, dentro do tema de "Estilos de Antropologia", no nosso caso, o de comparar os estilos de etnologia indígena que se praticam em contextos de países diversos - o Brasil, a Austrália, e o Canadá - com a possibilidade de abranger outros países com grupos étnicos minoritários, como a Argentina, a China e o Japão. A participação em redes internacionais de pesquisa levou à realização de uma pesquisa de três meses sobre etnologia indígena na Argentina em 2016, e uma visita técnica de cooperação internacional de dez dias com pesquisadores no Chile em janeiro de 2018.

\section{Nacionalidade e etnicidade em fronteira}

Após vários anos dedicados ao estudo de estilos de etnologia indígena, senti uma necessidade de realizar novas pesquisas etnográficas, de longo prazo, junto a povos indígenas. Desde a proibição de pesquisas independentes em Antropologia pelo Programa Waimiri-Atroari (FUNAI/ELETRONORTE), a partir da 
sua inauguração em abril de 1987, e a proibição da minha pesquisa nesta Terra Indígena a partir de junho de 1989, não havia como dar continuidade a este projeto etnográfico iniciado durante o doutorado na UnB. Ao conversar com o professor Roberto Cardoso de Oliveira, que havia voltado da UNICAMP para o CEPPAC/UnB (atualmente ELA/UnB), unidade acadêmica vinculada ao Instituto de Ciências Sociais (ICS) que abriga o Programa de Pós-Graduação em Estudos Comparados sobre as Américas, recebi convite para co-coordenar um projeto de pesquisa "Nacionalidade e Etnicidade em Áreas de Fronteira" (19982001) (Cardoso de Oliveira; Baines, 2005). A pesquisa sobre nacionalidade e etnicidade em fronteiras internacionais levanta muitas das questões teórico-metodológicas que contribuem para o estabelecimento de uma Antropologia em fronteiras como foi proposta por Cardoso de Oliveira (2005). Os trabalhos de Cardoso de Oliveira revelam uma preocupação com a presença de povos indígenas em fronteiras nacionais desde suas pesquisas junto aos Terenas na fronteira do Brasil com o Paraguai, entre 1955 e 1960 (1960; 1968), e junto aos Tikúnas, em 1959 e 1962 e 1975 (Cardoso de Oliveira, 1981 [1964]), dois povos indígenas que vivem em fronteiras internacionais.

$\mathrm{Na}$ sua proposta de estudar nacionalidade e etnicidade em áreas de fronteira, em projeto de pesquisa que não se restringia apenas a pesquisas com povos indígenas localizados em fronteiras, Cardoso de Oliveira afirma que,

É assim que em ambos os lados da fronteira pode-se constatar a existência de contingentes populacionais [...] diferenciados pela presença de indivíduos ou grupos pertencentes a diferentes etnias, sejam elas autóctones ou indígenas, sejam provenientes de outros países pelo processo de imigração. Ora, isso confere à população inserida no contexto de fronteira um grau de diversificação étnica que, somado à nacionalidade natural ou conquistada do conjunto populacional de um e de outro lado da fronteira, cria uma situação sócio-cultural extremamente complexa $(2005: 14)$.

\section{Cardoso de Oliveira acrescenta que}

No caso das etnias [...], não se trata mais de considerá-las em si mesmas, i. é, enquanto tais, mas de inseri-las num outro quadro de referência: o quadro (inter)nacional. A rigor, poder-se-ia dizer que tal quadro teria sua configuração marcada por um processo transnacional [...]. E é precisamente esse processo 
transnacional que, a meu ver, se impõe ao observador como uma instância empírica sujeita à descrição sistemática (Cardoso de Oliveira, 2005:14).

Ressalta, este autor, que

será num espaço internacional marcado pela contiguidade de nacionalidades distintas (e no interior dessas, supostamente, de etnias diversas), que surge o foco privilegiado de investigação: não mais o sistema interétnico... mas o sistema inter e transnacional, visto em termos das nacionalidades em conjunção (2005:15).

Ao participar deste projeto de pesquisa, resolvi, para minha pesquisa etnográfica, focalizar os povos indígenas Makuxi e Wapichana no trecho da fronteira do estado de Roraima com as Regiões 8 e 9 da República Cooperativa da Guiana. A região pertence ao Maciço Guianense Ocidental, mesma região onde eu havia realizado pesquisas para o doutorado junto aos Waimiri-Atroari entre 1982 e 1985 . Os povos indígenas escolhidos são localizados entre 300 e 550 km ao norte da Terra Indígena Waimiri-Atroari, em trecho de fronteira internacional que abrange a região entre a Terra Indígena Jacamim, predominantemente Wapichana no sul, passando pelas comunidades mistas de Pium, Manoá, Alto Arraia, e Canoanim, e seguindo ao norte pelas vilas de Bonfim e Normândia à comunidade de Lamero na Terra Indígena Raposa Serra do Sol e as comunidades de Maturuca, Uiramutã, Laje, e Willimon, predominantemente Makuxi, nesta mesma Terra Indígena, no norte. A pesquisa está sendo realizada nos dois lados da fronteira, abrangendo também Lethem, St. Ignatius e Kanapang na Guiana.

Iniciei pesquisa de campo nesta fronteira em janeiro/fevereiro de 1991, durante o recesso de aulas da UnB e venho realizando etapas curtas de pesquisa de campo nesta região de fronteira, anualmente, em períodos de recesso de aulas na UnB, o que facilita uma abordagem diacrônica sobre indígenas que vivem em esta fronteira. Mantenho contatos consolidados com interlocutores como o tuxaua Orlando Pereira da Silva, sua esposa Luíza Maria, seus filhos, netos, irmãos e genros que vivem em Uiramutã, Roraima, como com moradores em Santo Ignácio na Guiana, como o ex-prefeito indígena de Lethem, Muacir Baretto, sua esposa Emiline Baretto e família e Osmond e Eva Joseph e parentes, Mário Nicácio, ex-coordenador do Conselho Indígena de Roraima (CIR), Joênia Wapichana, advogada do CIR, que vem trabalhando na elaboração de regimes jurídicos indígenas, e diversos outros colaboradores, em uma pes- 
quisa que almeja ser participativa e colaborativa.

Ao abordar a questão de povos indígenas em fronteiras internacionais, além das reflexões teóricas apresentadas pelos autores na coletânea organizada por Roberto Cardoso de Oliveira \& Stephen Grant Baines (2005) Nacionalidade e Etnicidade em Fronteiras, dialogo com outros autores que abordam questões teóricas sobre fronteiras, como os artigos das coletâneas organizadas por Donnan \& Wilson (1994), O’Dowd \& Wilson (1996), e Wilson \& Donnan (1998), Grimson (2000), e com o colega do DAN/UnB, o professor José Pimenta que realiza pesquisas junto aos Ashaninka na fronteira do Acre com o Peru.

Trabalhos recentes de Sebastián Valverde e Gabriel Stecher (2013), e de Valverde (2013) sobre o povo Mapuche no sudoeste da Argentina enfocam questões de etnicidade e nacionalidade na fronteira Argentina-Chile. Nos últimos anos, estou participando de uma rede de pesquisa com os professores Sebastián Valverde da Universidade de Buenos Aires / CONICET, e Luis Eugenio Campos Muñoz da Universidad Academia de Humanismo Cristiano, Santiago Chile, ex-orientando de doutorado no DAN, UnB. Estes dois pesquisadores do Cone Sul realizam pesquisas sobre os Mapuche que vivem na fronteira internacional entre Argentina e Chile, tema também da dissertação de mestrado do ex-orientando Maxim Repetto, de nacionalidade chilena, atualmente professor da UFRR. Luis Eugenio Campos realiza pesquisa também junto a afrodescendentes na região de Arica, fronteira do Chile com Peru, e examina a relutância do Estado chileno em reconhecê-los como chilenos (2017).

Participei, também, do "Projeto ERENA: Etnicidade, Região e Nação: reconfigurando a teoria a partir de saberes locais e espaços transnacionais" (20032005), coordenado pelo professor Leandro Mendes Rocha na Universidade Federal de Goiás, que resultou na publicação de uma coletânea de coorganização:

- ROCHA, Leandro. Mendes; BAINES, Stephen Grant (orgs.) 2008. Fronteiras e Espaços Interculturais: transnacionalidade, etnicidade e identidade em regiões de fronteira. Goiânia: Ed. da Universidade Federal de Goiás.

Mais recentemente, o professor Giovani José da Silva da Unifap realizou estágio pós-doutoral sob a minha supervisão no DAN/UnB (2012-2013), focalizando o povo Camba-Chiquitano na fronteira Brasil-Bolívia.

Dentre os trabalhos mais recentes publicados nesta linha de pesquisa, estão:

- "Os povos indígenas Wapichana e Makuxi na fronteira Brasil-Guiana, 
região do Maciço Guianense.” Revista Brasileira do Caribe, v. XIII, p. 131 157, 2013.

- A organização do Dossiê "Povos Indígenas no Caribe Contemporâneo”, na Revista Brasileira do Caribe, São Luís: Edufma, 2013.

- "Povos Indígenas na Fronteira Brasil-Guiana e os megaprojetos de integração econômica”. Ciência e Cultura, v.65, p. 40 - 42, São Paulo: SBPC, 2013.

- "O movimento político indígena em Roraima - identidades indígenas e nacionais na fronteira Brasil-Guiana.” Caderno CRH. Salvador: UFBA, v.25, p. $33-44,2012$.

Ao longo de mais de 14 anos de etapas de pesquisa, consegui acompanhar a vida de diversos indígenas que vivem em comunidades ao longo desta fronteira, além de abordar a presença de indígena na capital de Roraima, Boa Vista, com a colaboração inestimável do então coordenador da Organização dos Indígenas da Cidade (ODIC), Eliandro Pedro de Souza, e da então estudante Evilene Tomás, e do professor Maxim Repetto da UFRR.

Tive a oportunidade, também, de participar, desde sua criação em 2001, do Núcleo Insikiran de Formação Superior Indígena na UFRR, coordenado inicialmente pela professora Maria Auxiliadora de Sousa Melo da UFRR, transformado a partir de 2009 no Instituto Insikiran de Formação Superior Indígena.

Maxim Repetto é professor do Instituto Insikiran desde sua criação e atualmente é coordenador do Programa de Pós-Graduação Sociedade e Fronteiras (PPGSOF) da UFRR. Participei nos cursos iniciais de seleção de candidatos entre os professores indígenas de Roraima e, ao longo dos anos, em aulas, minicursos e na apresentação das minhas pesquisas para os alunos indígenas do Instituto Insikiran em esforço de realizar um trabalho participativo e colaborativo. Este Instituto é caracterizado como um espaço interinstitucional de diálogo com as organizações e comunidade indígenas de Roraima, contanto com a participação de instituições governamentais e não governamentais nas discussões e decisões administrativas e políticas. O seu objetivo principal é a Licenciatura intercultural para capacitar professores indígenas em Licenciatura Plena com enfoque intercultural, para atuarem nas áreas de concentração: Ciências Sociais, Comunicação e Artes e Ciências da Natureza (Carvalho; Fernandes; Repetto, 2008). Atualmente conta com a Licenciatura Intercultural, o curso de Gestão Territorial Indígena (2009), e o Curso de Gestão em Saúde Coletiva Indígena 
(2013). O Instituto Insikiran foi criado a partir de uma demanda do movimento político indígena em Roraima para o reconhecimento das terras indígenas, e o atendimento diferenciado de saúde e educação, sendo a primeira experiência em uma Universidade Federal.

Em 2000, havia cerca de 600 professores indígenas em Roraima e, em 2015, o número estava acima de mil professores indígenas, com 280 escolas e, aproximadamente, 13 mil estudantes indígenas. Entre 2009 e 2010, 118 professores indígenas foram graduados pelo Instituto, que fornece uma capacitação em nível de licenciatura para os professores indígenas, e está facilitando a implantação de cursos de segundo grau nas comunidades indígenas, desta maneira, evitando a migração de jovens indígenas para a capital Boa Vista para seguir sua educação escolar.

Realizei pesquisa de campo com povos indígenas na fronteira internacional entre Roraima, Brasil e a República da Guiana, em 14 etapas (janeiro/2001, janeiro/2002, janeiro/2004, janeiro/2005, julho/2005, janeiro/2006, janeiro/2007, janeiro/2008, janeiro/2009, fevereiro/2011, janeiro/2012, janeiro/2014, janeiro/fevereiro 2015 e fevereiro de 2017) financiadas pelo CNPq.

O professor Roberto Cardoso de Oliveira, em seus trabalhos iniciais, ao abordar a questão dos povos indígenas que vivem em fronteiras internacionais, refere-se à "manipulação de identidade junto a representantes dos respectivos Estados nacionais” (Cardoso de Oliveira, 2000:17) em situações como a procura de assistência à saúde e educação dos filhos. A partir das pesquisas realizadas entre os Makuxi e Wapichana na fronteira Brasil-Guiana, observamos que a contextualização de identidades pelos indígenas que vivem nesta fronteira, apesar de parecer contraditória e ambígua - na perspectiva hegemônica do Estado nacional que pensa a nacionalidade como uma identidade exclusiva -, não é concebida dessa maneira por eles, pois não veem contradição alguma no fato de se identificarem como brasileiros e guianenses. Muitos são portadores de documentos de ambos os países. Quase todos têm parentes que vivem nos dois lados da fronteira. Não veem nenhuma ambiguidade em identificar-se conforme os contextos em que estão inseridos e que lhes parecem naturais. Tampouco veem contradição em identificar-se como Makuxi e Wapichana, e mesmo por outras identidades étnicas, ao terem familiares de mais de uma etnia em aldeias que atualmente são multiétnicas, além de serem transnacionais. Então, a afirmação de uma identidade nacional não seria uma manipulação de identidade do ponto de vista desses 
indígenas. Propomos o uso da noção de “identidades contextualizadas”, conforme se assume ora uma, ora outra nacionalidade, sabendo-se que, frequentemente, ambas as nacionalidades e duas ou mais identidades étnicas são assumidas simultaneamente. Embora os indígenas que vivem nessa fronteira pertençam a redes de parentesco que se estendem dos dois lados da fronteira para o interior desses países e muito além, e apesar de haver um fluxo de pessoas que transita constantemente pela fronteira, a presença dos Estados nacionais com políticas indigenistas e culturas muito diferentes criou uma situação em que os indígenas veem essas políticas como parte de dois mundos distintos, havendo poucas interações entre suas respectivas organizações indígenas. Na perspectiva dos indígenas que vivem na fronteira, o que se destaca são as contradições e as ambiguidades dos discursos governamentais dos respectivos Estados nacionais. Entendemos que o conceito de "identidades contextualizadas" atende melhor às perspectivas indígenas, enquanto, ao mesmo tempo, ajuda a entender a situação de indígenas que vivem nesta fronteira internacional, e "identidades indígenas transnacionais", ao se tratar de identidades que transcendem as fronteiras dos Estados.

A criminalização de indígenas no sistema penitenciário de Boa Vista, Roraima, e de Brasília, Distrito Federal

A pesquisa que estou realizando sobre a situação prisional de indígenas em Roraima complementa a pesquisa sobre povos indígenas na fronteira internacional, considerando que muitos dos indígenas presos nasceram em Terra Indígenas localizadas ao longo da fronteira, e outros nasceram na Guiana ou são descendentes de indígenas nascidos na Guiana, mantendo laços estreitos com comunidades indígenas nos dois lados da fronteira. Esta linha de pesquisa etnográfica se iniciou em janeiro de 2008, a partir de um levantamento realizado sobre indígenas no sistema penitenciário de Roraima, a convite de um ex-orientando do DAN/UnB, professor Cristhian Teófilo da Silva, do então CEPPAC/UnB, atual ELA/UnB, então tesoureiro da Associação Brasileira de Antropologia (ABA) que, na época, estava coordenando um levantamento sobre indígenas presos no Brasil, resultado de um acordo entre a ABA e o Ministério Público Federal (ABA/MPF). O levantamento em Roraima contou com a colaboração de dois alunos, orientandos meus da pós-graduação em antropologia da UnB a partir de julho de 2008, Alessandro Roberto de Oliveira e Walison Pascoal Vasconcelos.

Incorporei a pesquisa sobre a criminalização de indígenas no estado de 
Roraima, em meu projeto de pesquisa sobre indígenas na fronteira entre Brasil e Guiana, por ter uma relação estreita com a pesquisa sobre indígenas em fronteiras internacionais e migração indígena. Alguns indígenas detentos são nacionais da Guiana, outros são migrantes da Guiana que têm dupla nacionalidade, e ainda outros são descendentes de indígenas nascidos na Guiana que habitavam territórios tradicionais na atual região de fronteira desde antes da definição de esta fronteira internacional, em 1904. A questão da fronteira internacional está muito presente na vida cotidiana dos povos indígenas de Roraima, inclusive aqueles presos no sistema penitenciário do estado.

Para a pesquisa etnográfica sobre a situação prisional de índios no estado de Roraima, uso textos sobre direitos indígenas e sobre instituições totais e sistemas penitenciários, como os de Araújo (1995), Barreto (2006), Câmara (2001), Daunton-Fear \& Freiberg (1977), Foucault (1995; 2003), Goffman (2001), Jackson (1998; 2002), Nascimento (2003), Stephen (1999). Os artigos de professor de Direito da UBC e jurista, Michael Jackson, que há mais de trinta anos se envolve na questão de direitos humanos e indígenas no Canadá, com enfoque em direitos indígenas, havendo representado presos indígenas perante o Supremo Tribunal do Canadá, inclusive os casos de Delgamuukw e a nação Haida, oferecem reflexões importantes para a questão de indígenas no sistema penitenciário. Os trabalhos de Diana Eades (1997, 2000, 2006) que examina as enormes desvantagens enfrentadas por indígenas no sistema judicial e penitenciário na Austrália, fornecem reflexões relevantes para o estudo de indígenas presos. Todos esses trabalhos ajudam a pensar uma pesquisa comparada em etnologia indígena, e a questão de povos indígenas em fronteiras internacionais, além do tema da criminalização de indígenas.

Nesta linha de pesquisa, tenho um artigo no prelo no periódico internacional, Études Rurales, intitulado, "Indigenous people in the prison system of Roraima, Brazil: where constitutional differentiated indigenous rights are disrespected”, 2015.

E artigo publicado no livro que resultou do PROCAD/CAPES, UnB/UFPR, Faces da Indianidade, organizado por Maria Inês Smiljanic, José Vieira Pimenta, e Stephen G. Baines, Curitiba: Nexo Design, 2009, intitulado, "Esperando para ser julgado": Indígenas no sistema penitenciário de Boa Vista em Roraima”, p. 169-186. Apresentei palestras e trabalhos em simpósios e mesas redondas em eventos nacionais e internacionais nesta temática.

Os estudos feitos no estado de Roraima reforçam alguns dos resultados 
obtidos em estudos realizados em outros estados brasileiros (ABA/ESMPU, 2008), em que há uma descaracterização étnica de indígenas presos por policiais, advogados, juízes, o Secretário de Estado de Segurança Pública, a Secretaria de Estado de Justiça e Cidadania. Tal fato resulta em uma imprecisão das estatísticas oficiais sobre o número de presos indígenas e sua "invisibilidade legal" como sujeitos de direitos diferenciados. Há uma infinidade de situações que variam de incidentes internos nas comunidades indígenas em áreas rurais, em cidades, e na capital do estado, ocorrências envolvendo indígenas e não-indígenas, bem como indígenas nascidos e criados fora das Terras Indígenas. A autoidentificação como indígenas é frequentemente ambígua e contraditória, refletindo a ambiguidade da sociedade brasileira para com os indígenas, e muitos presos se identificam como indígenas apenas em certos contextos.

A inconsistência das informações nos cadastros prisionais em relação ao perfil étnico indígena da população carcerária é evidente. Quase todos os presos indígenas entrevistados negaram ter recebido qualquer tratamento diferenciado em decorrência de seus direitos específicos como indígenas. Tanto a população carcerária indígena e os jovens indígenas no centro de detenção juvenil são invisibilizados nas estatísticas institucionais. A opinião expressa pela maioria dos funcionários penitenciários e operadores do direito é que todos devem ser tratados de forma igual perante a lei, revelando um desconhecimento dos direitos constitucionais dos indígenas. Vários presos indígenas reivindicam um tratamento diferenciado, como penas alternativas, que poderiam ser servidas em Terras Indígenas no caso de ocorrências dentro de Terras Indígenas, com o consentimento das comunidades e dos conselhos dos tuxauas, e/ou uma ala separada nas penitenciárias. Considerando a estrutura desmedidamente assimétrica das relações interétnicas que fundamentam as práticas sociais, policiais e penais, é necessário considerar os obstáculos que os povos indígenas enfrentam para ter acesso à justiça e considerar as possibilidades de criação de instituições diferenciadas como penas alternativas, respeitando seus direitos constitucionais.

Esta linha de pesquisa está trazendo algumas mudanças. Desde janeiro de 2008, quando começamos este estudo, alguns indígenas presos no estado de Roraima começaram a exigir seus direitos diferenciados garantidos pela Constituição, o que se tornou assunto de debate nas organizações indígenas, como a ODIC na capital, Boa Vista, no CIR, e na Defensoria Pública do estado de Roraima. A possibilidade de criação de uma ala separada dentro das instituições 
prisionais para abrigar detentos indígenas tornou-se uma proposta do Ministério Público Federal em Roraima. Em 2014, o antropólogo Dr. Gustavo Hamilton de Souza Menezes, pesquisador com longa experiência na FUNAI, também iniciou uma pesquisa com indígenas presos em Roraima e em outros estados.

Apesar de avanços feitos no reconhecimento dos direitos indígenas na Constituição Federal de 1988, e por meio de legislação internacional, como a Convenção 169 da Organização Internacional do Trabalho (OIT), ratificada pelo Brasil em 2002, e a Declaração das Nações Unidas sobre os Direitos dos Povos Indígenas adotada pelo Brasil em 2007, o abismo entre a legislação e a prática é enorme e os direitos indígenas são constantemente desrespeitados. Em nenhum lugar isso é mais claro do que no sistema prisional onde prevalecem estereótipos racistas e onde os direitos indígenas continuam a ser desrespeitados. Uso a noção de "criminalização indígena" para abordar o encarceramento de indígenas e o desrespeito aos seus direitos diferenciados.

Esta pesquisa está em andamento, com visitas às unidades penitenciárias do estado de Roraima onde estou acompanhando a vida de indígenas encarcerados e o fluxo de presos indígenas, além de ampliar a pesquisa com a colaboração do Dr. Gustavo Menezes, para incluir indígenas presos no sistema penitenciário de Brasília, D.F. A continuação e ampliação de pesquisa etnológica sobre a criminalização de indígenas no sistema penitenciário de Boa Vista, Roraima e no Distrito Federal, focalizando a criminalização de indígenas, está rendendo resultados importantes ao fornecer aos indígenas presos informações sobre seus direitos diferenciados e chamar a atenção de órgãos do governo para a situação de criminalização de indígenas no sistema penitenciário.

Desde 2014, o pesquisador colaborador, Dr. Gustavo Menezes, que está realizando uma pesquisa de pós-doutorado sob a minha supervisão no DAN/UnB, e realizou uma etapa de três meses de pesquisa na Universidade da Colúmbia Britânica (UBC), Vancouver, Canadá, junto com o professor Bruce Granville Miller, iniciou um levantamento junto à FUNAI sobre indígenas presos, em que estou participando. O mesmo pesquisador me convidou a participar de visitas realizadas por uma equipe da FUNAI e do Departamento Penitenciário Nacional (DEPEN), Ministério da Justiça, a indígenas presos nas unidades penitenciárias de Brasília. Apesar de enfrentar dificuldades para obter acesso às penitenciárias do Distrito Federal (DF), a iniciativa oferece possibilidades de ampliar a pesquisa. Em 01 de julho de 2014, foi realizada a primeira reunião na sede do 
DEPEN, Brasília, com representantes da FUNAI, do DEPEN e do Ministério Público Federal e, em 3 de julho de 2015, a equipe realizou visitas à Colmeia (prisão feminina) e ao Centro de Detenção Preventiva (CDP) da Papuda, D.F. Em uma primeira visita à Colmeia, das 678 presas, cinco se autodeclararam indígenas, uma de etnia Bororo, uma de etnia desconhecida do Maranhão, uma de etnia desconhecida que residia em Unaí, Minas Gerais, e uma que declarou que seu pai e avós paternos são indígenas, do Piauí. No Centro de Detenção Provisória (CDP), em apenas uma ala, onde havia cerca de cento e vinte presos (sete celas com aproximadamente dezessete presos por cela), quatro detentos se autodeclararam indígenas: um que se autodeclara de etnia "Gamarra" do Paraguai, falante de tupi-guarani; outro de etnia desconhecida que declara que sua mãe e avó eram indígenas; um Tikúna, do estado do Amazonas; e um Guajajara de Barra do Corda, Maranhão. Isto numa população penitenciária total de 13.269 (Brasil, 2014) no DF. Considerando a dificuldade de conseguir autorização para entrar em outras unidades, ainda não foi possível averiguar o número de indígenas presos, que não constam nas estatísticas do Levantamento Nacional de Informações Penitenciárias INFOPEN - junho de 2014 (Brasil, 2014).

\section{Atividades acadêmicas e institucionais}

Iniciei carreira como professor de Antropologia no DAN/UnB, quando fui contratado pela UnB, em maio de 1989, apesar de entrar no quadro apenas em maio de 1990. Consegui me naturalizar brasileiro para superar a dificuldade de contratação. Ao longo dos vinte e seis anos de carreira no DAN/UnB até 2015 (ano da entrega deste Memorial para a ascensão à classe de professor titular), tenho compartilhado com os colegas uma carga didática intensa, e ofereci disciplinas sobre uma variedade de temas na Graduação e na Pós-Graduação. Na Graduação, ofereci as disciplinas: Introdução à Antropologia; Teoria Antropológica 1; Sociedades Indígenas; Identidade e Relações Interétnicas; Antropologia Política;Tópicos Especiais em Antropologia: Etnologia em contextos nacionais; Antropologia das Sociedades Complexas; e várias disciplinas de Tópicos Especiais em Antropologia sobre a Política na História da Antropologia e Estilos de Etnologia Indígena, além das disciplinas tutoriais, Seminário de Pesquisa; Excursão Didática de Pesquisa e Dissertação. Na Pós-Graduação, ofereci as disciplinas: Etnologia Sulamericana; Etnologia de Áreas Extra-continentais; Estilos de Antropologia (Etnologia Indígena no Brasil, no Canadá e na Austrália); Análise 
de Sistemas Interétnicos; Análise de Problemas Sociais; Tópicos Especiais em Etnologia: Etnologia Indígena Comparada: Brasil - Austrália - Canadá; Tópicos Especiais em Teoria Antropológica; e disciplinas tutoriais de "Elaboração de Trabalho Final” em teses de doutorado e dissertações de mestrado.

A partir de 2008, todas as disciplinas que ofereço no PPGAS/DAN são de dupla entrada com o PPG/ELA, onde participei anteriormente no projeto de pesquisa do professor Roberto Cardoso de Oliveira sobre nacionalidade e etnicidade em áreas de fronteira desde os anos 1990 e, considerando a afinidade da pesquisa comparada com os objetivos da minha pesquisa sobre estilos de etnologia indígena, e sobre o tema de nacionalidade e etnicidade em fronteiras, a partir de maio de 2008, fui credenciado pelo Colegiado do Programa de Pós-Graduação PPG/ELA/UnB para ministrar disciplinas de dupla entrada (DAN/ ELA) e também para orientar alunos do PPG/ELA ${ }^{3}$, assim abrindo espaço para orientações e intercâmbios com abordagens comparativas de caráter internacional, onde continuo atuando.

Minha incorporação ao corpo docente do ELA/UnB abriu espaço não somente para uma participação mais intensa em orientar pesquisas neste centro de pesquisa, mas se compatibiliza com a abordagem comparativa do meu projeto de pesquisa, além de facilitar a incorporação das abordagens comparativas em etnologia indígena dentro das metas do centro, estreitando o intercâmbio entre o ELA e o DAN, intercâmbio que existe desde os anos 1990. Pretendo manter e ampliar este intercâmbio ao longo dos próximos anos. Estes fatores levaram a uma nova linha de pesquisa que abre novos campos de reflexão, incentivando pesquisas inovadoras para além da etnologia indígena que se faz no Brasil, permitindo um alargamento do horizonte empírico.

Ao longo dos vinte e cinco anos que leciono na UnB, participei de diversas atividades institucionais:

- Entre 02/1995 e 01 / 1997, fui Coordenador da Pós-Graduação em Antropologia da UnB.

- Entre 12/1997 e 11/1999, fui membro suplente da Câmara de Carreira Docente (CCD), Conselho de Ensino, Pesquisa e Extensão da UnB.

- Entre 04/2005 e 03/2007, fui membro da Comissão de Pós-Graduação em Antropologia. Entre 03/2006 e 02/2009, fui representante do ICS na Câmara de Extensão da UnB.

- A partir de novembro de 2013, sou membro suplente da Câmara de Gestão 
de Pessoas, UnB, (Resolução do Conselho de Administração N. 0072/2013).

- Participei de numerosas comissões do DAN, do ELA, e do ICS/UnB para avaliar processos de progressão funcional, revalidação de diplomas, e outros, e de numerosas bancas de seleção de doutorado e de mestrado no DAN e no ELA.

- Em 2014, fui presidente da Comissão Examinadora do Exame de Seleção para Mestrado e Doutorado para candidatos indígenas 2014.

- Sou membro da Comissão Examinadora do Exame de Seleção para Mestrado e Doutorado para candidatos indígenas 2015.

- Sou membro da Comissão de Ações Afirmativas do DAN desde 2013, quando foi criada a referida Comissão.

- Entre 08/1989 e 03/1994, fui nomeado pelo colegiado do DAN representante na Associação de Docentes da Universidade de Brasília (ADUnB).

- Participei como Membro Titular Externo do Concurso Público para Professor Efetivo Adjunto, Campus Catalão, em Antropologia, Edital No. 7/2011, Universidade Federal de Goiás, entre 25 e 27 de abril de 2011.

- Participei como Membro da Comissão Examinadora de Concurso Público para a Classe de Professor Adjunto, 40h/DE, para área de conhecimento de “Antropologia Cultural”, no período de 25 a 28 de maio de 2009, RIR/RFR/ PURO/UFF, Faculdade Federal de Rio das Ostras, Rio de Janeiro.

- Participei da Comissão Examinadora de Concurso Público (Área Etnologia Indígena - Professor Adjunto/DE), 2006, Universidade de Brasília.

- Participei da Banca de Seleção Pública de Professor Substituto em Teoria Antropológica, DAN/UnB, 2005

- Participei do Concurso para seleção simplificada de Professor Visitante Adjunto, 1997, DAN/UnB, 2 de janeiro de 1997.

- Sou sócio efetivo da Associação Brasileira de Antropologia (ABA) desde 1986.

- Fui representante titular da ABA junto ao Ministério de Relações Exteriores, da Câmara Temática Conhecimento Tradicional Associado do Ministério do Meio Ambiente (2008-2010), a convite do então presidente da ABA, Professor Carlos Caroso.

- Fui membro do Comitê Povos Tradicionais, Meio Ambiente e Grandes Projetos, da ABA, a convite do então coordenador Professor Russell Parry Scott (UFPE) em 2014.

- Fui vice-coordenador do Comitê Povos Tradicionais, Meio Ambiente e Grandes Projetos da ABA para o Biênio 2015-2016 nomeado pelo então presi- 
dente da ABA, professor Antônio Carlos de Souza Lima, e atualmente sou coordenador do mesmo Comitê da ABA (2017-2018).

- Sou fundador do Grupo de Estudos em Relações Interétnicas (GERI) no DAN/UnB desde 1997, que foi transformado em Laboratório de Estudos em Relações Interétnicas (LAGERI) por decisão do colegiado do DAN/UnB, a partir de 03/2012, e se tornou uma Atividade de Extensão Universitária no DAN/UnB.

- De dezembro de 2015 a dezembro de 2017, fui membro da Banca Examinadora de Professor Associado - BEPA/UnB.

\section{Considerações complementares}

Ao longo destas últimas décadas, procurei fazer diversas contribuições teóricas e metodológicas para a compreensão da realidade social, econômica, cultural e política, sobretudo no que diz respeito à etnologia indígena, sempre mantendo uma perspectiva internacional a partir de comparações, o que incorporo nas disciplinas do PPGAS/DAN/UnB e no PPG/ELA/UnB, e nas disciplinas de Graduação do DAN/UnB. Também pretendi que meus estudos fossem, além de acadêmicos, úteis para pensar a situação dos povos indígenas. Minha participação no Instituto Insikiran de Formação Superior Indígena na UFRR, desde 2001, tem sido de grande valia neste sentido, ao abrir uma oportunidade de dialogar com alunos indígenas deste Instituto. Orientei a tese de doutorado de Gersem José dos Santos Luciano Baniwa, a primeira tese de doutorado em Antropologia defendida por um aluno indígena no Brasil, e atualmente oriento alunos indígenas do PPGAS/DAN. Participo na Comissão de Ações Afirmativas do DAN/UnB, além de ser presidente da primeira Comissão de Seleção de Alunos Indígenas por cotas no PPGAS/DAN/UnB em 2014 e membro da mesma Comissão em 2015.

\section{Atividades recentes}

Sou pesquisador do CNPq desde 1990. No pedido de bolsa de produtividade em Pesquisa de 2008, o Comitê Assessor me reclassificou como PQ-1A, permitindo aumento significativo da minha produção científica a partir deste ano, como se pode conferir no meu currículo Lattes. Desde a minha licença de Pós-doutorado no Canadá e na Austrália (1 de setembro de 2009 a 1 de agosto de 2010), intensifiquei os contatos estabelecidos com pesquisadores/professo- 
res universitários nesses países e minha participação em eventos internacionais.

Alguns dos professores contatados estão contribuindo na troca de material bibliográfico: professor Bruce Granville Miller da Universidade da Columbia Britânica (UBC), Vancouver, Canadá; professora Francesca Merlan da Australian National University (ANU), Camberra, Austrália; professora Emma Kowal, da Deakin University, Australia; entre muitos outros. Além disso, desde 1998, mantenho contato com a juíza indígena especialista em direitos indígenas, Patricia Paul Aqiimuk, Washington State, EUA, próxima à fronteira entre os EUA e o Canadá. Patricia Paul Aqiimuk facilitou umas visitas a comunidades indígenas no estado de Washington, EUA, durante minha licença de Pós-doutorado no Canadá, que têm laços estreitos com parentes que vivem nos dois lados da fronteira internacional entre os EUA e o Canadá. Mantenho, também, contatos com uma ampla rede de colegas pesquisadores em etnologia indígena no Brasil, o que permite uma nova contribuição à pesquisa na área de etnologia indígena brasileira, enriquecida por comparações com trabalhos etnográficos realizados por pesquisadores no Canadá, na Austrália e na Argentina.

O Laboratório e Grupo de Estudos em Relações Interétnicas (LAGERI), que coordeno, vem servindo como laboratório de estudos e pesquisas para a discussão em equipe de trabalhos dentro da temática de relações interétnicas, inclusive, as pesquisas individuais de alunos de pós-graduação (em níveis de doutorado e mestrado) e alunos da graduação, pesquisadores realizando estágios de pós-doutorado no DAN/UnB, e do ELA/UnB, professores da UnB, alunos indígenas do PPGAS/DAN/UnB, lideranças indígenas, e acadêmicos de outras instituições, pesquisadores internacionais que realizam pesquisas no Canadá, na Austrália, e em outros países. O LAGERI constitui uma atividade de Extensão da UnB estreitamente relacionada às minhas atividades de pesquisa para unir as atividades de alunos da Pós-Graduação e da Graduação, além de colegas do corpo docente do DAN e do ELA, e de outras Universidades, e pesquisadores nacionais e internacionais.

Estou participando intensamente na coordenação de Simpósios, Grupos de Trabalho, e Mesas Redondas em eventos científicos nacionais e internacionais ao longo dos últimos anos, o que se tornou possível com recursos da Bolsa de Produtividade em Pesquisa nível 1A, incorporando alunos orientandos do PPGAS/ DAN/UnB, do ELA/UnB, alunos de programas de Pós-Graduação de outras Universidades, e colegas de diversas Universidades no Brasil e no exterior. 
Nos últimos anos, aumentou muito a minha produção acadêmica em publicações nacionais e internacionais, como se pode averiguar por meu currículo Lattes.

\section{Publicações recentes (2012 a setembro de 2015)}

Artigos em periódicos:

1. BAINES, S. G. Politiques indigénistes au Brasil, au Canada et en Australie - Les défits de la pratique anthropologique dans divers contextes nationaux. Recherches Amérindiennes au Québec, v. XLIV, Nos. 2-3, 2014, p. 5-12, (Publicado em 2015).

2. BAINES, S. G., Resenha de livro RIBEIRO, Gustavo Lins; ESCOBAR, Artur (orgs.) 2012, Antropologias Mundiais - transformações da disciplina em sistemas de poder. Brasília Editora, UnB. Anuário Antropológico, v. 2013, I, p. 259 - 262, (Publicado em 2014).

3. BAINES, S. G. Os povos indígenas Wapichana e Makuxi na fronteira Brasil-Guiana, região do Maciço Guianense. Revista Brasileira do Caribe, v. XIII, p. 131- 157, 2013. Dossiê "Povos Indígenas no Caribe Contemporâneo", organizado por Stephen Grant Baines. São Luís: Edufma. Impresso e on-line. Home page disponível em: <http://www.periodicoseletronicos.ufma.br/index.php/ rbrascaribe $>$. Acesso em: 23/09/2017.

4. BAINES, S. G. Povos Indígenas na Fronteira Brasil-Guiana e os megaprojetos de integração econômica. Ciência e Cultura, v.65, no. 1, p. 40-42, 2013. São Paulo: Sociedade Brasileira para o Progresso da Ciência (SBPC).

5. BAINES, S. G. O movimento político indígena em Roraima - identidades indígenas e nacionais na fronteira Brasil-Guiana. Caderno $C R H$ (UFBA), v.25, p. 33-44, 2012.

6. BAINES, S. G. Social Anthropology with Indigenous Peoples in Brazil, Canada and Australia - a comparative approach. Vibrant (Florianópolis), v.9, p. 209-238, 2012. Dossier "Challenges in Brazilian Anthropology", Guest Editor: Bela Feldman-Bianco, Vibrant (Virtual Brazilian Anthroplogy) v9 n1 01-06/201230 p.

\section{Capítulos de livros publicados}

1. BAINES, S. G. Terras Indígenas na fronteira Brasil-Guiana, nordeste de Roraima. In: RODRIGUEZ, José Exequiel Basini, et al. (orgs.) Povos tradicionais, fronteiras e geopolítica na America Latina: uma proposta para a Amazônia. 1 ed. 
Manaus:Valer, 2015, v.1, p. 69-92.

2. BAINES, S. G. A usina hidrelétrica Balbina e o Programa Waimiri-Atroari (des)articulação da etnicidade. In: RODRIGUES, Lea Carvalho; SILVA, Isabelle Braz Peixoto da (orgs.). Saberes locais, experiências transnacionais - Interfaces do fazer antropológico. 1 ed. Fortaleza: ABA Publicações, 2014, v.1, p. 207-217.

3. BAINES, S. G. As usinas hidrelétricas na Amazônia - o indigenismo empresarial e a insustentabilidade de grandes hidrelétricas em Terras Indígenas. In: ZHOURI, Andréa (org.). Desenvolvimento, Reconhecimento de Direitos e Conflitos Territoriais. 1 ed. Brasília: ABA Publicações, 2014, v.1, p. 98-121.

4. BAINES, S. G. Relações interétnicas na fronteira Brasil-Guiana: reafirmação étnica entre os povos indígenas Makuxi e Wapichana In: TRINCHERO, Hugo; MUÑOZ, Luis Campos; VALVERDE, Sebastián (orgs.) Pueblos indígenas, Estados nacionales y fronteras Tensiones y paradojas de los procesos de transición contemporáneos en América Latina, Tomo II. 1 ed. Buenos Aires: Editorial de la Facultad de Filosofía y Letras Universidad de Buenos Aires, 2014, v.2, p. 169-194.

5. BAINES, S. G. Globalização, Estados nacionais e povos em situação de fronteira - a terra indígena Raposa Serra do Sol, Roraima, e a questão da soberania nacional. In: RODRIGUEZ, José Exequiel Basini, et al. (Orgs.) Fronteiras, Diálogos e Intervenção Social no Contexto Pan-Amazônico. $1^{\text {a }}$. ed. Manaus: Editora e Livraria da UFAM - EDUA, 2013, v. 1, p. 259-266.

6. BAINES, Stephen G.; JOSÉ DA SILVA, Giovani. Os Outros e os Confins das Fronteiras - presenças indígenas em limites de Estados nacionais. In: BRITO, Adilson J. I.; ROMANI, Carlo; BASTOS, Carlos Augusto (orgs.) Fronteiras em Questão - múltiplos olhares. 1 ed. Campo Grande: Editora UFMS, 2013, v. 1, p. 113-135.

7. BAINES, S. G. Relações interétnicas na região da fronteira entre o Brasil e a Guiana. In: BRITO, Adilson J. I.; ROMANI, Carlo; BASTOS, Carlos Augusto (orgs.) Limites Fluentes - fronteiras e identidades na América Latina (Séculos XVIII-XXI). 1 ed. Curitiba: Editora CRV, 2013, v.1, p. 63-76.

8. BAINES, S. G. Capítulo 3, A Terra Indígena Raposa Serra do Sol: direitos indígenas ameaçados? In: PINTO, Simone Rodrigues (org.). Políticas públicas e desigualdades sociais. $1^{\text {a }}$. ed. Brasília: Paralelo 15, 2012, v.1, p. 63-69.

9. LUSTOSA, Isis Maria Cunha, BAINES, Stephen G. Capítulo 9, Os Tremembé do litoral nordestino e um empreendimento turístico internacional. In: BAINES, Stephen Grant; TEÓFILO DA SILVA, Cristhian; FLEISCHER, David Ivan Rezende; FALEIRO, Rodrigo Paranhos (orgs.). Variações Interétnicas - etnici- 
dade, conflito e transformações. 1 ed. Brasília: Centro Nacional de Informação Ambiental - CNIA - IBAMA, 2012, v.1, p. 229-245.

10. BAINES, S. G. Identidades e protagonismo político indígena no Brasil após a Constituição Federal de 1988. In: PIMENTA, José; SMILJANIC, Maria Inês (orgs.) Etnologia Indígena e Indigenismo. 1 ed. Brasília: Positiva, 2012, p. 31-51.

11. BAINES, S. G. 4. Identidades indígenas e nacionais entre dois Estados nacionais - os Macuxi e Wapichana na fronteira Brasil-Guiana. In: SILVA, Sidney Antônio da (Org.). Migrações na Pan-Amazônia - fluxos, fronteiras e processos socioculturais. 1 ed. São Paulo: HUCITEC EDITORA FAPEAM, 2012, v.1, p. 93-103.

\section{Livros organizados:}

1. BAINES, S. G. Dossiê Povos Indígenas no Caribe contemporâneo. São Luis: Edufma, v. XIII, no.25-Jul-Dez, 2012, p.328. Organização do Dossiê Povos Indígenas no Caribe contemporâneo, Revista Brasileira do Caribe, São Luis, MA, Brasil: Edufma, vol. XIII, (publicado em 2013). Artigos de 13 autores publicados no Dossiê. Home page: http:/ /www.periodicoseletronicos.ufma.br/index. $\mathrm{php} / \mathrm{rbrascaribe}$

2. BAINES, S. G., SILVA, C. T., FLEISCHER, D. I., FALEIRO, R. P. Variações interétnicas: etnicidade, conflitos e transformações. Brasília: IBAMA; UnB/ELA; IEB; CAPES, 2012, v.1. p. 559.

\section{Pesquisas:}

O Projeto individual do coordenador, Stephen G. Baines focaliza os temas seguintes:

1. Desdobrar em nova etapa um estudo comparativo da etnologia indígena que se faz na Austrália e no Canadá, a partir do estilo de etnologia que se faz no Brasil, e incluir estudos sobre a Antropologia com povos indígenas e grupos étnicos minoritários em outros países como a Argentina.

2. Examinar os conceitos de indianidade, aboriginalidade, etnicidade, e raça, nos países focalizados, traçar a relação entre esses conceitos e os estilos de etnologia indígena que se constituíram historicamente, e a relação entre Antropologia e política indigenista nos casos estudados.

3. Aprofundar uma análise da relação entre o desenvolvimento da etnologia indígena e a construção da nação nos países focalizados.

4. Dar continuidade a uma pesquisa etnográfica junto aos Makuxi e aos Wapi- 
chana dentro da linha de pesquisa sobre etnicidade e nacionalidade em fronteiras internacionais. A proposta incorpora alunos da Pós-Graduação, da Graduação, e supervisão de pesquisadores em estágios de Pós-Doutorado em pesquisas sobre povos indígenas em fronteiras internacionais.

5. Dar continuidade a uma pesquisa etnográfica sobre a criminalização de indígenas no sistema penitenciário de Boa Vista, Roraima, ampliando a pesquisa para incluir, também, uma pesquisa etnográfica sobre indígenas no sistema penitenciário do Distrito Federal.

6. Reforçar a consolidação de uma equipe de alunos do PPGAS/DAN/UnB e do PPG/ELA/UnB, e de Graduação em Antropologia da UnB na área de etnologia indígena, realizando pesquisas dentro da tradição etnológica no Brasil de abordar tanto o estudo de aspectos internos de sociedades indígenas como as relações entre as sociedades indígenas e os Estado nacionais em que vivem, políticas indigenistas e movimentos políticos indígenas. Pretende-se continuar aproveitando o estudo de estilos de etnologia indígena no Canadá, na Austrália e na Argentina, como pontos de reflexão e diálogo teórico para consolidar uma abordagem teórica internacional.

7. Desde 2000, estou acompanhando a situação do povo indígena Tremembé no litoral oeste do Ceará (sem utilizar recursos do CNPq), onde meu ex-orientando, atualmente professor Cristhian Teófilo da Silva do ELA/UnB, preparou o laudo antropológico que resultou na demarcação e homologação da Terra Indígena Córrego João Pereira, a primeira Terra Indígena a ser regularizada no estado do Ceará. Realizei visitas a Almofala e à Terra Indígena Córrego João Pereira, nos municípios de Itarema e Acaraú, em julho de 2000. Desde 2007, estou acompanhando a pesquisa da Dra. Isis Maria Cunha Lustosa (Laboratório de Estudos e Pesquisas das Dinâmicas Territoriais - Laboter / Universidade Federal de Goiás - UFG) em visitas a estas mesmas comunidades e também às comunidades de Varjota, e Buriti e Sítio São José no município de Itapipoca em janeiro e em julho de 2007, em janeiro de 2008, em julho de 2008, e em janeiro de 2009, janeiro de 2011, janeiro de 2012, julho de 2013 e janeiro de 2017. Nas comunidades de Buriti e Sítio São José, na Barra do rio Mundaú, junto à mesma pesquisadora, estou acompanhando o impacto de um mega-projeto de turismo internacional, "Nova Atlântida”, que vem ameaçando estas duas comunidades e suas terras, e o processo de reelaboração étnica que está acontecendo, sendo uma situação etnográfica contrastante com as outras pesquisas que estou realizando em etnologia indígena. 
Em janeiro de 2009, julho de 2009, e em janeiro de 2011, 2012 e 2015, janeiro e novembro de 2017, realizei visitas também ao povo indígena Jenipapo-Kanindé da Terra Indígena Aldeia Lagoa Encantada, outra área de pesquisa com a Dra. Lustosa, no município de Aquiraz, onde estão construindo um projeto de turismo de base comunitária que tem parceria com a Rede Tucum e com o Departamento de Geografia da UFC.

Todos os alunos que oriento, como também outros alunos que cursam disciplinas que estou ministrando, estão incorporando bibliografia da área de etnologia indígena no Brasil, na Austrália e no Canadá, de forma comparativa, que aborda os estilos de etnologia indígena e questões diretamente relacionadas às relações interétnicas entre povos indígenas e Estados nacionais. Estou consolidando e renovando um grupo de pesquisa em etnologia indígena que abrange pesquisadores doutores que são ex-orientandos meus, e alunos orientandos em níveis de doutorado, mestrado e graduação, além de pesquisadores em estágios de pós-doutorado. O DAN/UnB é um dos melhores centros de excelência em pesquisa etnológica do país (nível 7 da CAPES), o que facilita constituir um grupo de pesquisa fortemente integrado. Considerando a alta produção do coordenador e os membros do projeto de pesquisa, em estudos sobre diversos temas em etnologia indígena, porém, unidos dentro de uma orientação teórica comum que privilegia questões sobre estilos de etnologia em países diversos, justifica-se o seu desdobramento. Além de ter consolidado uma equipe de pesquisadores em etnologia indígena, reforçado nas atividades do LAGERI.

No desdobramento desta pesquisa, estou aplicando a minha formação acadêmica em Antropologia Social em nível de doutorado no Brasil, em etnologia indígena sob a orientação do professor Julio Cezar Melatti (tese defendida no DAN/UnB no início de 1988), minha formação anterior em nível de mestrado em Antropologia da Universidade de Cambridge, Inglaterra (dissertação defendida em 1980), e minha experiência como pesquisador bolsista do CNPq no Museu Paraense Emílio Goeldi (1988-89), e como professor do DAN/UnB (a partir maio de 1989) e pesquisador do CNPq desde 1991, como um caso paradigmático para examinar a etnologia indígena que se faz no Canadá, na Austrália e na Argentina. Com a publicação de artigos em português, inglês, francês e espanhol, estimulam-se diálogos entre antropólogos no Brasil, na Austrália, no Canadá, na Argentina e em outros países.

Atualmente, meu ex-orientando, Cristhian Teófilo da Silva (ELA/UnB) está 
continuando esta linha de pesquisa comparativa entre o Canadá e o Brasil, a partir do LAEPI/ELA/UnB, que foi criado em 28 de março de 2011, no ELA/ UnB e tem uma parceria estreita com o LAGERI/DAN/UnB.

Minhas atividades de pesquisa visam incentivar pesquisas comparativas no DAN e no ELA/UnB, além de dar continuidade a pesquisas etnográficas junto a povos indígenas no Brasil e estimular novos alunos a seguir pesquisas nessas áreas.

Venho mantendo contatos pessoais com antropólogos australianos, canadenses, e argentinos que realizam pesquisas com sociedades indígenas por meio de participação em eventos científicos nestes países e em outros países (Chile, Argentina, México, Cuba, Áustria - nos três anos e meio até setembro de 2015, participei de 58 eventos científicos internacionais e nacionais), e por meio do correio eletrônico, com a divulgação e intercâmbio de publicações em redes com antropólogos no Brasil, na Austrália e no Canadá, além da coleta de um acervo de artigos e livros na área de etnologia indígena nestes países. Estou usando material bibliográfico sobre a etnologia indígena na Austrália e no Canadá, na orientação de alunos em nível de Pós-Graduação e de Graduação, e nas bibliografias das disciplinas ministradas desde 1991 no DAN/UnB.

As pesquisas de pós-doutorado na Austrália e no Canadá conduziram à oferta de várias disciplinas em "Estilos de Etnologia Indígena: Brasil, Austrália e Canadá” e "Etnologia Indígena em contextos nacionais", tanto na Graduação como na Pós-Graduação em Antropologia, permitindo a incorporação de um conteúdo bibliográfico internacional e comparativo.

\section{Pesquisadores colaboradores}

Professor Cristhian Teófilo da Silva, Professor Associado I, ELA/UnB (ex-orientando no DAN/UnB) Laboratório de Estudos e Pesquisas em Movimentos Indígenas Políticas Indigenistas e Indigenismo (LAEPI) criado em 2011. Bolsista de Produtividade de Pesquisa nível 2, do CNPq.

Professor Maxim Repetto (Professor Associado 1, do Instituto Insikiran, de Formação Superior Indígena, e Coordenador do Programa de Pós-Graduação Sociedade e Fronteiras (PPGSOF), UFRR (ex-orientando no DAN/UnB).

Professor Bruce Granville Miller, professor titular do Departamento de Antropologia, University of British Columbia, Vancouver. Ph.D. Arizona, 1989, Contatos profissionais de pesquisa com o prof. Stephen G. Baines desde 1995, na UBC, Canadá. Desde 2008 participa na coordenação de simpósios e GTs 
em eventos internacionais de Antropologia comigo, no Brasil, no Canadá e nos Estados Unidos da América. Ofertou disciplina de leitura junto com Stephen G. Baines no PPGAS/DAN em 2009, participou das 2 aulas da disciplina do PPGAS/DAN/UnB, "Estilos de Antropologia: Etnologia Indígena no Brasil, Canadá e Austrália" no $1^{\circ}$ semestre de 2015, apresentou seminários no LAGERI/ DAN/UnB, e seminário no Centro de Estudos Ameríndios (CEstA), Universidade de São Paulo (USP), em 27/04/2015, junto comigo.

Professora Barbara Glowczewski, Directrice de recherche (DR1) no CNRS, Laboratoire d'Anthropologie Sociale, França. Pesquisas com povos indígenas na Austrália desde 1979. Visitou o DAN, UnB em 2013, quando apresentou palestra e em 2015, apresentou palestra no LAGERI, DAN, UnB em 20.03.2015, Seminário do DAN, participou em 2 aulas da disciplina do PPGAS/DAN, "Estilos de Antropologia: Etnologia Indígena no Brasil, Canadá e Austrália”, ministrada pelo professor Stephen G. Baines no $1^{\circ}$ semestre de 2015.

Professor Francesca Merlan, ProfessorTitular de Antropologia, ANU College of Arts and Social Sciences, Camberra, Austrália. Foi minha supervisora acadêmica durante o pós-doutorado na ANU, Austrália em 2010.

Professor Sebastián Valverde, Professor da Universidad de Buenos Aires, Argentina. Pesquisador do CONICET. Realizou visitas ao DAN/UnB, seminários no LAGERI. Pesquisas sobre o povo indígena Mapuche na fronteira internacional Argentina-Chile e sobre indígenas na cidade de Buenos Aires. Coordenação de eventos científicos em Antropologia e organização de publicações com o professor Stephen G, Baines.

Professora Emma Kowal, professora da Deakin University, Austrália, Pesquisa sobre políticas indigenistas e contato interétnico na Austrália. Visitou o DAN/UnB e apresentou palestra no LAGERI/DAN/UnB em 09.10.2014.

Professor Giovani José da Silva, professor da Unifap. Realizou estágio pós-doutoral sob a supervisão do Prof. Dr. Stephen G. Baines (2012-2013).

Professor Rodrigo Grünewald, professor associado, UFCG. Coordenador do Laboratório de Estudos sobre Tradições (LETRA/UFCG).

\section{Inserções e parcerias}

As atividades de pesquisa estão desenvolvidas em cooperação com outros pesquisadores, tanto do ELA/UnB quanto de outras instituições, como o Instituto Insikiran de Formação Superior Indígena da UFRR e o Programa de Pós- 
-Graduação Sociedade e Fronteiras (PPGSOF)/UFRR. A pesquisa envolve intercâmbios internacionais com o Departamento de Antropologia da Universidade da Colúmbia Britânica (UBC), com a colaboração do Professor Bruce Granville Miller (parte de pós-doutorado na UBC, Vancouver, Canadá, sob a supervisão acadêmica do professor Bruce Miller, e atividades acadêmicas no Brasil e no Canadá e EUA junto com este professor desde 2008), e com o Departamento de Antropologia, Australian National University (ANU) em Camberra, Austrália (parte de pós-doutorado na ANU, Austrália sob a supervisão acadêmica da professor Francesca Merlan), e outros pesquisadores interessados como a professora Barbara Glowczewski do College de France, especialista em etnologia indígena na Austrália, e professor Sebastián Valverde da Universidade de Buenos Aires (UBA), CONICET, Argentina, que realiza pesquisas junto aos Mapuche no sudoeste da Argentina em fronteira com o Chile, e com indígenas na cidade de Buenos Aires.

Ao longo dos últimos anos, estou tendo um intercâmbio muito proveitoso que inclui participação em atividades acadêmicas com o professor João Pacheco de Oliveira do Museu Nacional/UFRJ, cujos trabalhos na linha de pesquisa de povos indígenas e Estados nacionais têm sido de grande valia nas minhas pesquisas desde o período em que estava escrevendo minha tese de doutorado (1986-88).

Nos últimos dois anos, venho estreitando parcerias com a professora Eliane Cantarino O’Dwyer, da Universidade Federal Fluminense (UFF), Rio de Janeiro, na co-coordenação de eventos.

Participo em Grupos de Pesquisa cadastrados no Diretório de Grupos de Pesquisa no Brasil do CNPq:

"Movimentos Indígenas, Políticas Indigenistas e Indigenismo", no "Laboratório de Estudos e Pesquisas em Movimentos Indígenas Políticas Indigenistas e Indigenismo" (LAEPI/ELA/UnB), 2011, coordenado pelo prof. Cristhian Teófilo da Silva no ELA/UnB, Colaboração e intercâmbio com o Professor Cristhian Teófilo da Silva que antes colaborava na organização do LAGERI. Parceria com o LAGERI/DAN/UnB.

"Laboratório de Estudos sobre Tradições" (LETRA) (UFCG), coordenado pelo prof. Rodrigo de Azeredo Grünewald (UFCG), 2013. Participei da banca de doutorado do Rodrigo de Azeredo Grünewald no Museu Nacional/UFRJ e, desde então, mantenho contatos acadêmicos.

“Cidadanias Interculturais, Povos Indígenas, Populações Amazônicas e 
Estudos Transdisciplinares”(UFRR), 2008, na Universidade Federal de Roraima, coordenado pelo prof. Maxim Repetto, que participou da criação do antigo GERI/DAN/UnB em 1997, quando aluno de doutorado no DAN/UnB. Professor do Instituto Insikiran de Formação Superior Indígena, e Coordenador do PPGSOF/UFRR.

"História, Antropologia e Relações Internacionais em fronteiras" (UNIFAP), 2013, coordenado pelo prof. Giovani José da Silva que realizou estágio de pós-doutorado no DAN/UnB sob a minha supervisão.

Participo como membro das Comissões (Organizadora/Científica) no Brasil e no exterior do "Colóquio Internacional de Turismo em Terras Indígenas e de Comunidades Tradicionais (CTurTI)”, que tem estreita parceria com o LAGERI, sendo um evento itinerante na América Latina, idealizado/coordenado pelas professoras doutoras Maria Geralda Almeida e Isis Maria Cunha Lustosa, da Universidade Federal de Goiás (UFG), Instituto de Estudos Socioambientais (IESA), Laboratório de Estudos e Pesquisas das Dinâmicas Territoriais (Laboter), desde sua I edição em 2013, atualmente em sua IV edição em novembro de 2017.

\section{Considerações finais}

Venho me dedicando exclusivamente a atividades de ensino e pesquisa, mantendo uma alta produção científica em publicações internacionais e nacionais, com projeto de pesquisa que demonstra relevância, originalidade e repercussão da produção científica, com participação intensa na formação contínua de recursos humanos em nível de Pós-Graduação na área de Antropologia, trazendo uma contribuição científica e de inovação à área de Etnologia Indígena no Brasil e, internacionalmente, por meio da pesquisa comparativa com Canadá, Austrália, e Argentina, além de pesquisas sobre povos indígenas em fronteiras internacionais e pesquisas comparativas sobre a criminalização de indígenas.

Pretendo continuar a liderar um grupo de pesquisa em etnologia indígena fortemente consolidado, garantindo uma inserção internacional, por meio de palestras e assessorias ad hoc a revistas nacionais e internacionais e de órgãos de financiamento à pesquisa, bem como envolvimento em atividades de gestão científica e acadêmica, como a participação contínua na Comissão de Ações Afirmativas no DAN/UnB, em que participo desde 2013, e em Comissões Examinadoras do Exame de Seleção para Mestrado e Doutorado para candidatos indígenas para o PPGAS/DAN/UnB, em que participei como presidente em 2014, ano em que 
o Colegiado do DAN/UnB aprovou uma política de cotas para candidatos indígenas no PPGAS/DAN, e em que participei como membro em 2015.

Participo, como membro do corpo editorial de periódicos, e na organização de eventos. As atividades de pesquisa visam ter impactos sociais na Antropologia ao ampliar diálogos horizontais entre colegas em centros de etnologia indígena em países não-hegemônicos da disciplina como o Brasil, o Canadá, a Austrália, a Argentina e o Chile, além de ter impactos sociais de comunicação com a sociedade nas áreas de pesquisa etnográfica ao analisar situações vividas por povos indígenas que vivem em fronteiras internacionais e focalizar situações de criminalização de indígenas e seu encarceramento em penitenciárias.

As atividades de pesquisa revelam uma significativa liderança dentro da área de Etnologia Indígena no Brasil e capacidade de explorar novas fronteiras cientificas ao trazer uma abordagem eminentemente internacional na pesquisa sobre estilos de etnologia indígena em contextos nacionais, e abordar questões como: indígenas em fronteiras internacionais e a criminalização de indígenas em penitenciárias.

Desde minha reclassificação pelo $\mathrm{CNPq}$ em bolsa de produtividade em pesquisa nível PQ-1A, minha produção vem crescendo progressivamente (nos anos 2006-2008 produção $175^{4}$; nos anos 2009-2011, aumento para 254; nos anos 2012-2014, aumento para 353, e incluindo a produção até julho de 2015 produção total de 431), havendo quase dobrado a produção acadêmica nos últimos três anos e meio em relação aos três anos anteriores.

Nos cinco anos entre 2010 e 2015, minha produção total é de 619, comparada com os cinco anos anteriores, quando minha produção total era de 289, revelando um crescimento significativo. Após minha reclassificação como bolsista PQ-1A, a produção foi a mais alta de minha carreira.

No período de 2012 a julho de 2015, recebi Menção Honrosa no Prêmio CAPES/MEC de Tese, como orientador da tese de doutorado de Gersem José dos Santos Luciano Baniwa, a primeira tese de doutorado em Antropologia defendida por um aluno indígena no Brasil, e recebi o Prêmio Pesquisador Parceiro da Imprensa Edição 2013 da Secretaria de Comunicação da Universidade de Brasília.

$\mathrm{Na}$ minha produção para toda minha carreira acadêmica, conforme o Curriculum Lattes, até setembro de 2015, constam 72 artigos publicados em periódicos, 34 capítulos de livros, 1 livro de autoria individual, e 6 livros organizados. No mesmo período, concluí a orientação de 14 dissertações de mestrado, 8 teses de doutorado, 16 dissertações de Graduação, 21 trabalhos de Iniciação Científica, 
e 7 supervisões de pós-doutorado.

Nos período de 2010 até setembro de 2012, tive oito artigos publicados em periódicos nacionais e internacionais, 3 artigos aceitos para publicação em periódicos internacionais (uma dos quais de coautoria), 1 artigo de divulgação popular na Argentina, 12 capítulos de livros publicados, 3 livros organizados (um, individualmente, e outros junto com colegas), 10 trabalhos completos e 16 resumos publicados em anais de eventos, 2 artigos em jornais de notícias, 106 apresentações de trabalhos e palestras em eventos nacionais e internacionais (Brasil, Canadá - incluindo a AAA em Montreal, Áustria, México, Cuba, Argentina e Chile), além de ter publicado 2 posfácios e 1 capa de livro, ter realizado 161 trabalhos técnicos (muitos dos quais, pareceres ad hoc, incluindo pareceres para periódicos nacionais e internacionais), 24 trabalhos na mídia, e a organização e coordenação do LAGERI. No mesmo período, concluí a orientação de 8 dissertações de Mestrado, 3 teses de doutorado, 6 dissertações de Graduação, das quais 3 eram de Iniciação Científica, e supervisionei 6 pesquisas de Pós-Doutorado.

Em setembro de 2015, tinha em andamento 7 orientações de Doutorado (1 das quais uma co-orientação de Doutorado conjunto internacional UnB, Brasil/ UBC, Canadá), 2 orientações de Mestrado, 1 supervisão de pós-doutorado, e 5 orientações de Graduação, 2 das quais são de Iniciação Científica.

No mesmo período (2010-2015), participei de 26 bancas de Mestrado, 8 bancas de Doutorado, 13 bancas de qualificação de Doutorado, 6 bancas de Graduação, e 9 bancas de qualificação de Mestrado, e participei, com a apresentação de trabalhos, de 103 eventos nacionais e internacionais, e participei na organização de 29 eventos (incluindo coordenação de Simpósios, Grupos de Trabalho, Mesas Redondas, e participação em Comissões Organizadoras e Científicas). Participei, também, de uma banca de concurso público para professor, e 25 bancas de comissões julgadoras.

As linhas de pesquisa são fortemente articuladas, abarcando questões relacionadas a etnologia indígena, políticas indigenistas, movimentos indígenas, as relações entre povos indígenas e Estados nacionais, povos indígenas em fronteiras internacionais, e a criminalização de indígenas, utilizando bibliografias com uma maior ênfase dos três países, em publicações e em trabalhos apresentados em conferências. No mesmo período recebi 2 concessões auxílio-pesquisa para orientandos da Pós-Graduação (Editais Universais/CNPq), com avanços 
teóricos importantes. A pesquisa em Roraima foi ampliada para incluir novos orientandos da Pós-Graduação. Venho mantendo uma intensa participação em eventos científicos nacionais e internacionais, além de manter e fortalecer um grupo de pesquisa consolidado e internacional na área de etnologia indígena no DAN/UnB.

Recebido: 31/12/2017

Aprovado: 19/01/2018

\section{Notas}

1. A companheira de longos anos e também parceira de pesquisa no Brasil e no exterior, Dra. Isis Maria Cunha Lustosa, o meu reconhecimento por todo o seu apoio e colaboração ao longo das etapas deste concurso.

2. Editora do Museu Paraense Emílio Goeldi/CNPq

3. Em 2008, chamava-se Centro de Pesquisa e Pós-Graduação sobre as Américas (CEPPAC). Atualmente nominado Departamento de Estudos Latino-Americanos (ELA).

4. A produção expressa no Currículo Lattes do $\mathrm{CNPq}$ é a produção acadêmica total durante um período, que abrange todas as atividades acadêmicas.

\section{Referências bibliográficas}

ABA/ESMPU (Associação Brasileira de Antropologia/Escola Superior do Ministério Público da União) 2009. "Processos de Criminalização Indígena em Roraima/ Brasil”, Edital Projeto de Pesquisa ESMPU No. 98/2007, Final Report, Convênio: Procuradoria Geral da República-PGR Associação Brasileira de Antropologia-ABA. Coordenadores: Stephen Grant Baines (UNB); Cristhian Teófilo da Silva (UNB). Equipe: Alessandro Roberto de Oliveira (UNB); Walison Vasconcelos (UNB), Brasília, Distrito Federal.

ABA/ESMPU (Associação Brasileira de Antropologia/Escola Superior do Ministério Público da União) 2008. "Criminalização e Situação Prisional de Índios no Brasil” (Edital Projeto de Pesquisa ESMPU n¹9/2006). Relatório Final Convênio: Procuradoria Geral da República-PGR Associação Brasileira de Antropologia-ABA Coordenador: Cristhian Teófilo da Silva (ABA, UnB), Brasília, Distrito Federal.

ALTMAN, Jon; HINKSON, Melinda. (orgs.) 2007. coercive reconciliation: stabilize, normalize, exit Aboriginal Australia. North Carlton, Australia: Arena Publications Association. 
ALTMAN, Jon. 2007. "In the name of the Market?" In: ALTMAN, J.; HINKSON, M. (orgs.) 2007. coercive reconciliation: stabilize, normalize, exit Aboriginal Australia. North Carlton, Australia: Arena Publications Association, p. 307-321.

AMIT, Vered. 2006. "Just a little off-centre or not peripheral enough? Paradoxes for the reproduction of Canadian anthropology”. In: HARRISON, J.; DARNELL, R. (orgs.). Historicizing Canadian Anthropology. Toronto: University of Toronto press. p. 266-274.

ARAÚJO, Ana Valéria. 1995. Defesa dos direitos indígenas no judiciário: Ações Propostas pelo núcleo de direitos indígenas. São Paulo: Instituto Socioambiental.

AUSTIN, John L. 1962. How to do things with words. Oxford: Oxford University Press.

AUSTIN-BROOS, Diane. 2009. Arrernte Present, Arrernte Past: invasion, violence, and imagination in Indigenous Central Australia. Chicago: University of Chicago Press.

AUSTIN-BROOS, Diane, 2011. A Different Inequality: the politics of debate about remote Aboriginal Australia. Crows Nest, NSW, Australia: Allen \& Unwin.

AZZAN JÚNIOR, Celso. 2004. Antropologia e sociedade no Quebec: antes e depois da Revolução Tranquila. São Paulo: Annablume.

BAINES, Stephen Grant. 1991a. É a FUNAI que sabe:A Frente de AtraçãoWaimiri-Atroari. Belém: Museu Paraense Emílio Goeldi/ CNPq/ SCT/ PR. (Coleção Eduardo Galvão).

BAINES, Stephen Grant. 1991b. “Etnologia e Indigenismo na Austrália”. Série Antropologia 115. Brasília: Departamento de Antropologia, Universidade de Brasília.

BAINES, Stephen Grant. 1993. "First Impressions from a Brazilian Perspective on the Study of Aboriginal Populations in Social Anthropology in Australia”. Série Antropologia 144. Brasília: Departamento de Antropologia, Universidade de Brasília.

BAINES, Stephen Grant. 1995. "Primeiras impressões sobre a etnologia indígena na Austrália”. In CARDOSO DE OLIVEIRA, R.; RÚBEN, G.R. (orgs.). Estilos de Antropologia, Campinas: Editora da UNICAMP, (Coleção Repertórios), p. 65-119.

BAINES, Stephen Grant. 1996a. “Etnologia Indígena no Canadá: Primeiras Impressões”. Série Antropologia, 196, Brasília, Departamento de Antropologia, Universidade de Brasília.

BAINES, Stephen Grant. 1996b. "Social Anthropology with Aboriginal Peoples in Canada: First Impressions”. Série Antropologia, 197, Brasília, Departamento de Antropologia, Universidade de Brasília.

BAINES, Stephen Grant. 2003. “Organizações Indígenas e legislações indigenistas no Brasil, na Austrália e no Canadá”. Arquivos do Museu Nacional. (61-2), p. 115-128. 
BAINES, Stephen Grant. 2004. “Antropologia do desenvolvimento e a questão das sociedades indígenas”. Revista Anthropologicas, ano 8, volume 15(2), p. 29-46.

BAINES, Stephen Grant. 2012. "Social Anthropology with Indigenous Peoples in Brazil, Canada and Australia - a comparative approach”. Vibrant (Florianópolis), v.9, n.1, p. 209-238, Artigo em Dossier “Challenges in Brazilian Anthropology”, Guest Editor: Bela Feldman-Bianco, Vibrant (Virtual Brazilian Anthroplogy). Disponivel em: <http://www.vibrant.org.br/issues/v9n1/1>. Acesso em: 23 ago. 2015.

BALIKCI, Asen. 1980. "Faux combats; tristes arènes' un commentaire”. Recherches amérindienne au Québec, 10, (1-2), p. 124.

BANIWA, Gersem José dos Santos Luciano. 2006. O índio brasileiro: o que você precisa saber sobre os povos indígenas no Brasil de hoje. Brasília: MEC/SECAD; LACED/Museu Nacional, (Coleção Educação Para Todos. Série Vias dos Saberes n. 1). BANIWA, Gersem José dos Santos Luciano. 2009. "Indígenas no ensino superior: novo desafio para as organizações indígenas e indigenistas no Brasil”. In: SMILJANIC, Maria Inês; PIMENTA, José Vieira; BAINES, Stephen Grant. (orgs.), Faces da Indianidade. Curitiba: Nexo Design. p. 187-202.

BANIWA, Gersem José dos Santos. 2011. Educação para Manejo e Domesticação do Mundo - entre a escola ideal e a escola real: os dilemas da educação escolar indígena no Alto Rio Negro. Tese de doutorado em Antropologia, Universidade de Brasília.

BARRETO, Fabiana Costa Oliveira. 2006. Flagrante e prisão provisória na criminalização de furto: da presunção de inocência à antecipação de pena. Dissertação de Mestrado (Direito). Brasília: Universidade de Brasília.

BECKETT, J. R. 1992. Aboriginality and the Nation State: A Comparative Perspective. University of Sydney, ms.

BECKETT, Jeremy R. 1988a. "Introduction", p. 1-10 e "The past in the present; the present in the past: constructing a national Aboriginality", p. 191-214. In: BECKETT, Jeremy R. (ed.), Past and Present: the construction of Aboriginality, Canberra: Aboriginal Studies Press.

BECKETT, Jeremy R. 1988b. Aboriginality, citizenship and the Nation State. In: Aborigines and the State in Australia, Social Analysis. 24, p. 3-18.

BERNDT, Ronald M.; TONKINSON, Robert (eds.). 1988. Social Anthropology and Australian Aboriginal Studies: a contemporary overview. Canberra: Aboriginal Studies Press.

BLASER, Mario; FEIT, Harvey; MCRAE, Glenn. (eds.). 2004. In theWay of Development: Indigenous peoples, life projects and globalization. London \& New York: Zed Books.

BRADY, Maggie. 2005. Indigenous Australia and alcohol policy: meeting difference with 
indifference. UNSW Press.

BRASIL, 2014. Ministério da Justiça (MJ). Departamento Penitenciário Nacional (DEPEN), Levantamento Nacional de Informações Penitenciárias (INFOPEN) - junho de 2014, Disponível em: <http:/ / www.justica.gov.br/seus-direitos/politica-penal/ transparencia-institucional/estatisticas-prisional/infopen_jun14.pdf $>$. Acesso em: 23 jun. 2015.

CÂMARA, Heleusa Figueira. 2001. Além dos muros e das grades: Discursos Prisionais. São Paulo: EDUC.

CAMPOS, Luis Eugenio, 2017. "Los negros no cuentan. Acerca de las demandas dereconocimiento de los afrodescendientes en Chile y la exclusión pigmentocrática”. Revista Antropologías del Sur Año 4 N 8 p. 15 - 31.

CARDOSO DE OLIVEIRA, Roberto. 1960. Do Índio ao Bugre: o processo de assimilação dos Terêna. Rio de Janeiro: Edição Museu Nacional, Série Livros I.

CARDOSO DE OLIVEIRA, Roberto. 1981 [1964]. O Índio e o Mundo dos Brancos. Brasília - São Paulo: Editora UnB - Pioneira, $3^{\mathrm{a}}$ edição.

CARDOSO DE OLIVEIRA, Roberto. 1968. Urbanização e Tribalismo: a integração dos Terêna numa sociedade de classes. Rio de Janeiro: Zahar Editora.

CARDOSO DE OLIVEIRA, Roberto. 1978. A Sociologia do Brasil Indígena. Brasília - Rio de Janeiro: Editora UnB/ Tempo Brasileiro.

CARDOSO DE OLIVEIRA, Roberto. 1988a. Sobre o Pensamento Antropológico. Rio de Janeiro: Tempo Brasileiro; Brasília: CNPq. Biblioteca Tempo Universidade nº 83.

CARDOSO DE OLIVEIRA, Roberto. 1988b. A crise do indigenismo. Campinas: Editora da UNICAMP.

CARDOSO DE OLIVEIRA, Roberto; RÚBEN, Guilherme Raul (orgs.). 1995. Estilos de Antropologia, Campinas: Editora da UNICAMP, (Coleção Repertórios).

CARDOSO DE OLIVEIRA, Roberto. 1995b. “Identidade catalã e ideologia étnica”. Mana: estudos de Antropologia Social, 1 (1), p. 9-47.

CARDOSO DE OLIVEIRA, Roberto. 1998. O trabalho do antropólogo. Brasília: Paralelo 15; São Paulo: Editora UNESP.

CARDOSO DE OLIVEIRA, Roberto. 2000. "Os (des)caminhos da identidade. Revista Brasileira de Ciências Sociais, São Paulo, v.15, n.42, p. 7-21.

CARDOSO DE OLIVEIRA, Roberto. 2005. "Introdução”. In: CARDOSO DE OLIVEIRA, Roberto; BAINES, Stephen Grant (orgs.). Nacionalidade e etnicidade em fronteiras. Brasília: Editora Universidade de Brasília, (Coleção Américas), p. 9-20.

CARDOSO DE OLIVEIRA, Roberto; BAINES, Stephen Grant (orgs.). 2005. 
Nacionalidade e Etnicidade em Fronteiras. Brasília: Editora Universidade de Brasília, (Coleção Américas).

CARVALHO, Fábio Almeida; FERNANDES, Maria Luíza; REPETTO, Maxim (Orgs.). 2008. Projeto político-pedagógico da licenciatura intercultural / Núcleo Insikiran / UFRR. Boa Vista. Editora da UFRR.

CORRÊA, Mariza. 1987. História da Antropologia no Brasil (1930-1960), Vol. 1 Testemunhos: Emílio Willems, Donald Pierson. São Paulo: Vértice, Editora Revista dos Tribunais; Campinas, S.P.: Editora da UNICAMP.

COWLISHAW, Gillian. 2004. Blackfellas whitefellas and the hidden injuries of race. Malden, Oxford, Carlton: Blackwell Publishing.

DaMATTA, Roberto. 1973. "O carnaval como rito de passagem”. In: DaMATTA, Roberto. Ensaios de Antropologia Estrutural. (org.). Petrópolis: Vozes. p. 121-168.

DaMATTA, Roberto. 1981. "Digressão: A fábula das três raças, ou o problema do racismo à brasileira”. In: DaMATTA, Roberto. Relativizando: uma Introdução à Antropologia Social, Petrópolis: Vozes, 2a ed., p. 58-85.

DARNELL, Regna. 2001. Invisible Genealogies: a history of Americanist anthropology. Lincoln \& London: University of Nebraska Press.

DAUNTON-FEAR, MaryW.; FREIBERG, Arie. 1977. "Section II, Minority groups and the criminal justice system". In: CHAPPEL, Duncan; WILSON, Paul. (Orgs.) The Australian Criminal Justice System. Sydney, Melbourne, Brisbane, Adelaide, Perth: Butterworths.

DONNAN, Hastings.; WILSON, Thomas M. (orgs.) 1994. Border Approaches: anthropological perspectives on frontiers. Lanham, Maryland; London: University Press of America, Inc.

DRUMMOND, Lee. 1983. “'News show politics and the absent anthropologist' a discussion”. In: MANNING, F. (ed.). Consciousness and Inquiry: Ethnology and Canadian Realities. National Museum of man Mercury Series. Ottawa: National Museums of Canada. p. 108-111.

DYCK, Noel. (ed.) 1985. Indigenous Peoples and the Nation State: FourthWorld Politics in Canada, Australia and Norway. St John's Institute for Social and Economic Research, University of Newfoundland.

DYCK, Noel. 1990. "Cultures, Communities and Claims: Anthropology and Native Studies in Canada”. Canadian Ethnic Studies, XXII, 3, p. 40-55.

DYCK, Noel. with a Foreword by Grand Chief Alphonse Bird. 1997. Differing Visions: administering Indian residential schooling in Prince Albert, 1867-1995. Halifax: Fer- 
nwood Publishing; Prince Albert: The Prince Albert Grand Council.

DYCK, Noel. 2006. "Canadian anthropology and the ethnography of 'Indian Administration"”. In: J. Harrison; R. Darnell. Historicizing Canadian Anthropology. Toronto: University of Toronto press. p. 78-92.

DYCK, Noel; WALDRAM, James B. (orgs.) 1993. Anthropology, Public Policy and native Peoples in Canada. Montreal \& Kingston, London, Buffalo: McGill-Queen's University Press.

EADES, Diana. 1997. "Language in Court: The acceptance of linguistic evidence about indigenous Australians in the criminal justice system”. Australian Aboriginal Studies, Vol. 1, p. 15-27.

EADES, Diana. 2000. “I don't think it's an answer to the question”: Silencing Aboriginal witnesses in court. Language in Society, 29(2), p. 161-196.

EADES, Diana. 2006. "Interviewing and examining vulnerable witnesses". Encyclopedia of Language and Linguistics, 2nd ed. Ed. by Keith Brown. Elsevier: Oxford, p. 772-777.

FARAGE, Nádia. 1986. As Muralhas do Sertão: os povos indígenas no rio Branco e a colonização. Rio de Janeiro: Paz e Terra; ANPOCS.

FÍGOLI, Leonardo Hipólito. 1990. A Ciência sob o Olhar Etnográfico: Estudo da Antropologia Argentina. Tese de doutorado, Departamento de Antropologia, Universidade de Brasília.

FÍGOLI, Leonardo Hipólito G. 1995. “A antropologia na Argentina e a construção da nação”. In: CARDOSO DE OLIVEIRA, Roberto; RUBEN, Guilherme Raul (orgs.). Estilos de Antropologia. Campinas, SP: Editora da UNICAMP. p. 31-63.

FOUCAULT, Michel. 1995. Microfísica do poder. Rio de Janeiro: Graal.

FOUCAULT, Michel. 2003. Vigiar e punir: nascimento da prisão. $27^{\mathrm{a}}$ edição. Petrópolis: Vozes.

FRY, Peter. 2004. “Internacionalização da disciplina”. In: TRAJANO FILHO, Wilson; RIBEIRO, Gustavo Lins (orgs.) O Campo da Antropologia no Brasil. Rio de Janeiro: Contra Capa Livraria; Associação Brasileira de Antropologia, p. 227-248.

GALLOIS, Dominique Tilkin. 2005 (org.). Redes de relações nas Guianas. São Paulo: Associação Editorial Humanitas: Fapesp, (Série Redes Ameríndias - NHII-USP).

GEERTZ, Clifford. 1973. "The Politics of Meaning”. In: GEERTZ, Clifford. The Interpretation of Cultures. New York: Basic Books.

GOFFMAN, Erving. 2001. Manicômios, prisões e conventos. São Paulo: Perspectiva.

GOLD, Gerald L.; PAINE, Robert. 1984. "Introduction”. In: GOLD, Gerald L. (org.) Minorities and Mother Country Imagery. Social and Economic Papers No.13. St. John's, Newfoundland: Institute of Social and Economic Research, Memorial Univer- 
sity of Newfoundland.

GOULET, Jean-Guy A.; MILLER, Bruce Granville (orgs.). 2007. Extraordinary Anthropology: transformations in the field. Lincoln \& London: University of Nebraska Press.

GRIMSON, Alejandro et al., 2000. Fronteras nacionales e identidad: la periferia como centro. Buenos Aires: Ediciones Ciccus - La Crujía.

HAMILTON, Annette. 1982. "Anthropology in Australia: Some notes and a few queries”. In: McCALL, G. (ed.). Anthropology in Australia: Essays to Honour 50 Years of Mankind. The Anthropological Society of New South Wales. p. 91-106.

HARRIS, Douglas C. 2001. Fish, Law, and Colonialism: the legal capture of salmon in British Columbia. Toronto, Buffalo, London: University of Toronto Press.

HARRISON, Julia; DARNELL, Regna. 2006a. Historicizing Canadian Anthropology. Toronto: University of Toronto press.

HARRISON, Julia; DARNELL, Regna. 2006b. "Historicizing traditions in Canadian anthropology”. In: HARRISON, Julia; DARNELL, Regna. Historicizing Canadian Anthropology. Toronto: University of Toronto press. pp. 3-16.

HART, Cherie. 1991. “A Brazilian Tribe Escapes Extinction”, Edição Especial da RevistaWorld Development: Aiding Remote Peoples, vol.04, n.2, PNUD.

HASENBALG, Carlos A.; SILVA, Nelson do Valle; BARCELOS, Luiz Cláudio. 1992. “Capítulo 4 - Notas sobre miscigenação racial no Brasil”. In: HASENBALG, Carlos A.; SILVA, Nelson do Valle. (orgs.). Relações raciais no Brasil contemporâneo. Rio de Janeiro: Rio Fundo Editora: IUPERJ. p. 67-77.

HAVEMANN, Paul (ed.). 1999. Indigenous Peoples Rights in Australia, Canada, and New Zealand. Auckland; Oxford; Melbourne; New York: Oxford University Press.

HINKSON, Melinda. 2010. "Introduction: Anthropology and the culture wars". In: ALTMAN, Jon; HINKSON, Melinda (orgs.) 2010. Culture Crisis: Anthropology and Politics in Aboriginal Australia. UNSW Press, Sydney, p. 1-13.

HODGINS, Bruce W.; MILOY, J.S.; MADDOCK, Kenneth J., 1989. “Aboriginal Self-Government": Another Level or Order in Canadian and Australian Federalism? In HODGINS, Bruce. W.; EDDY, John; GRANT, Shelagh; STRUTHERS, John. (eds.) Federalism in Canada and Australia: Historical Perspectives, 1920-1988. Peterborough, Canada:The Frost Centre for Canadian Heritage and Development Studies, Trent University. p. 452-487.

HOWES, David. 2006. "Constituting Canadian anthropology". In: HARRISON, Julia; DARNELL, R. Historicizing Canadian Anthropology. Toronto: University of Toronto Press. p. 200-211. 
JACKSON, Michael. 2002. Justice Behind the Walls: Human Rights in Canadian Prisons. Vancouver: Douglas \& McIntyre. Disponivel em: <http://www.justicebehindthewalls.net/book.asp?cid=1>. Acesso em: 24 set. 2016.

JACKSON, Michael. 1989. "Locking Up Natives in Canada”. UBC Law Review, Vol. 23:2, p. 215-300.

KAPFERER, Bruce. 1989. "Nationalist Ideology and a Comparative Anthropology". Ethnos, (54), (3-4), p. 161-199.

KEW, Michael. 1993-94. "Anthropology and First Nations in British Columbia". BC Studies, Special Issue Number 100, Winter, p. 78-105.

KOWAL, Emma. 2011. "The Stigma of White Privilege: Australian anti-racists and Indigenous improvement”. Cultural Studies Vol. 25, No. 3 May 2011, pp. 313-333

KOWAL, Emma, 2008. "The Politics of the Gap: Indigenous Australians, Liberal Multiculturalism, and the End of the Self-Determination Era”. American Anthropologist, Vol. 110, Issue 3, p. 338-348.

KOWAL, Emma. 2006. "Moving Towards the Mean: Dilemmas of Assimilation and Improvement”. In: LEA Tess; KOWAL Emma; COWLISHAW Gillian (eds). Moving Anthropology: Critical Indigenous Studies. Darwin: Charles Darwin University Press, p.65-78.

KRAMER, Jennifer. 2006. Switchbacks: art, ownership, and Nuxalk national identity. Vancouver, Toronto: UBC Press.

LARAIA, Roque de Barros. 1986. “Os Estudos de Parentesco no Brasil”. Série Antropologia 55. Brasília: DAN, UnB.

LARAIA, Roque de Barros. 1987. "Etnologia indígena brasileira: um breve levantamento”. Série Antropologia, 60. Brasília: DAN, UnB.

L'ESTOILE, Benoît de; NEIBURG, Federico; SIGAUD, Lygia. (orgs.) 2002. Antropologia, Impérios e Estados Nacionais. Rio de Janeiro: Relume Dumará.

LIMA, Antônio Carlos de Souza. 1995. Um grande cerco de paz: poder tutelar, indianidade e formação do Estado no Brasil. Petrópolis: Vozes.

LIMA, Antônio Carlos de Souza; BARROSO-HOFFMANN, Maria (orgs.). 2002a. Além da Tutela: bases para uma nova política indigenista III. Rio de Janeiro: Contra Capa Livraria/LACED.

LIMA, Antônio Carlos de Souza; BARROSO-HOFFMANN, Maria (orgs). 2002 b. Estados e Povos Indígenas: bases para uma nova política indigenista II. Rio de Janeiro: Contra Capa Livraria/LACED.

MANNING, Frank. 1983. "Confusion and creative engagement: a comment on Canadian ethnology”. In: MANNING, Frank. (ed.) Consciousness and Inquiry: Ethnology 
and Canadian Realities. National Museum of Man Mercury Series. Ottawa: National Museums of Canada. p. 2-10.

McCALL, Grant. 1982. "Anthropology in Australia: introductory remarks”. In: McCALL, Grant. (ed.) Anthropology in Australia: essays to honour 50 years of Mankind. The Anthropological Society of New South Wales. p. 1-21.

McCARTHY, FREDERICK David. 1982. "Anthropology in the Museums of Australia”. In: McCALL, Grant. (ed.) Anthropology in Australia: essays to honour 50 years of Mankind. The Anthropological Society of New South Wales. p. 22-47.

MELATTI, Julio Cezar. 1982. “A Etnologia das populações indígenas do Brasil nas duas últimas décadas”. Anuário Antropológico (80). Rio de Janeiro: Tempo Brasileiro, p. 253-257.

MELATTI, Julio Cezar. 1984. “A Antropologia no Brasil: um roteiro”. BIB (Boletim Informativo e Bibliográfico de Ciências Sociais), (17), p. 3-52.

MERLAN, Francesca. 1988. Caging the rainbow: places, politics, and Aborigines in a North Australian town. Honolulu: University of Hawai'i Press.

MERLAN, Francesca, 2010. “Child Sexual Abuse: The Intervention Trigger”. In: HINKSON, Melinda; ALTMAN, Jon (eds.). 2010. Culture Crisis:Anthropology and Politics in Aboriginal. Australia, UNSW Press, Sydney, p. 116-135.

MILLER, Bruce Granville (Org.) 1992. BC Studies: A Theme Issue: Anthropology and History in Courts. no. 95.

MILLER, Bruce Granville. 2000. The Problem of Justice: tradition and Law in the Coast Salish World. Lincoln \&London: University of Nebraska Press.

MILLER, Bruce Granville. 2003. Invisible Indigenes: the politics of nonrecognition. Lincoln \& London: University of Nebraska Press.

MILLER, Bruce Granville. 2007. (ed.). Be of Good Mind: essays on the Coast Salish. Vancouver, Toronto: UBC Press.

MILLER, Bruce Granville. 2011. Oral History on Trial. Vancouver: UBC Press.

MORPHY. Howard. 2007. Becoming Art: exploring cross-cultural categories. Oxford; New York: Berg.

MORRIS, Barry. 1991[1988]. "Dhan-gadi resistance to assimilation”. In: I. Keen (ed.), Being Black: Aboriginal cultures in 'settled' Australia. Canberra: Aboriginal Studies Press, p.33-63.

MORRIS, Barry; LATTAS, Andrew. 2010. "Embedded Anthropology and the Intervention". Arena. Disponivel em: <http://www.arena.org.au/2010/09/embedded-anthropology-and-the-intervention/>. Acesso em: 24 set. 2016. 
MORSE, Bradford. 1988a. "Aboriginal-government relations in Australia and the implications for Canada”. In: LONG, Anthony; BOLDT, Menno; LEROY LITTLE BEAR (eds.), Governments in Conflict: Provinces and Indian Nations in Canada. p.209-221. Toronto: University of Toronto Press.

MORSE, Bradford. 1988b. Quebec secession and self-determination of First Nations. Faculty of Law, University of Ottawa, ms.

MUSHARBASH, Yasmine. 2008. Yuendumu Everyday: contemporary life in remote Aboriginal Australia. Canberra: Aboriginal Studies Press.

MYERS, Fred. 2002. Painting cultures. Durham, NC: Duke University Press.

NAMEM, Alexandro; CARNEIRO, O. de L.; RODRIGUES, L.A.; TOMAZ, E. de S.; FIORETTI, Elena C., 1995. Trabalho e Marginalização Indígena em BoaVista (Roraima) Projeto de Pesquisa. Universidade Federal de Roraima, Instituto de Antropologia e História, Departamento de Antropologia, Departamento de História, UFRR. BoaVista, Roraima.

NARAYAN, Kirin. 1993. How native is a native anthropologist? American Anthropologist, Vol. 95(3), p. 671-686.

NASCIMENTO, Nívio Caixeta do. 2003. Entre as leis e o mundo: Polícia e Administração de conflitos numa perspectiva comparativa. Tese de Doutorado em Antropologia Social. Brasília: PPGAS/DAN/UnB.

O’DOWD, Liam; WILSON, Thomas M. (orgs.) 1996. Borders, Nations and States: frontiers of sovereignty in the New Europe. Aldershot; Brookfield USA; Hong Kong; Singapore; Sydney: Avebury.

OLIVEIRA FILHO, João Pacheco de. 1988. O nosso governo: os Ticuna e o regime tutelar. São Paulo: Marco Zero; Brasília: MCT/CNPq.

OLIVEIRA FILHO, João Pacheco de (org.) 1989. Os Poderes e as Terras dos Índios. Rio de Janeiro: UFRJ/PPGAS, Museu Nacional (Comunicação Nº14).

OLIVEIRA FILHO, João Pacheco de (org.) 1990. Projeto Calha Norte: Militares, Índios e Fronteiras. Rio de Janeiro: Editora UFRJ/PETI, Museu Nacional.

OLIVEIRA FILHO, João Pacheco de (Org.). 1998. Indigenismo e territorialização:poderes, rotinas e saberes coloniais no Brasil contemporâneo. Rio de Janeiro: Contra Capa Livraria.

OLIVEIRA FILHO, J. P. de (org.) 1999a. A viagem de volta: etnicidade, política e reelaboração cultural no Nordeste indígena. Rio de Janeiro: Contra Capa Livraria Ltda.

OLIVEIRA FILHO, João Pacheco de. 1999b. Ensaios em Antropologia Histórica. Rio de Janeiro: Editora UFRJ, 1999.

OLIVEIRA FILHO, João Pacheco de. 2004. (org.). AViagem da volta: etnicidade, política e reelaboração cultural no Nordeste indígena. Rio de Janeiro: Contra Capa Livraria/ 
LACED, $2^{a}$ ed.

OLIVEIRA FILHO, João Pacheco de. "Pluralizando Tradições Etnográficas: sobre um certo mal-estar na Antropologia”. Cadernos do LEME, Campina Grande, (1), (1), p. 2-27. jan./jun. 2009. Disponível em: <http://www.ufcg.edu.br/ leme/pdf/leme_ jpo.pdf $>$. Acesso em: 05 nov. 2011.

OLIVEIRA FILHO, João Pacheco de; IGLESIAS, Marcelo Piedrafita. 2002. "As demarcações participativas e o fortalecimento das organizações indígenas.” In: SOUZA LIMA, Antonio Carlos de; BARROSO HOFFMANN, Maria. (orgs.). Estado e Povos Indígenas: bases para uma nova política indigenista II. Rio de Janeiro: Contra Capa Livraria/ LACED, p. 41-68.

OLIVEIRA FILHO, João Pacheco de; SANTOS, Ana Flávia Moreira. 2003. Reconhecimento Étnico em Exame: dois estudos sobre os Caxixó. Rio de Janeiro: Contra Capa Livraria e LACED/MN/UFRJ.

OLIVEN, Ruben George. 2004. "A reprodução da antropologia no Brasil”. In: TRAJANO FILHO, Wilson.; RIBEIRO, Gustavo Lins (orgs.). O Campo da Antropologia no Brasil. Rio de Janeiro: Contra Capa Livraria; Associação Brasileira de Antropologia, p. 213-226.

PAINE, R. 1977. TheWhite Arctic:Anthropological Essays on Tutelage and Ethnicity. Newfoundland Social and Economic Papers N ${ }^{\circ}$.7, St. John's, Newfoundland: Institute of Social and Economic Research, Memorial University of Newfoundland.

PAINE, Robert. 1983. "News show politics and the absent anthropologist." In: MANNING, F. (ed.). Consciousness and Inquiry: Ethnology and Canadian Realities. National Museum of Man Mercury Series. Ottawa: National Museums of Canada, p. 108-111.

PEIRANO, Mariza G. S. 1991 [1981]. The Anthropology of Anthropology: The Brazilian Case. Tese de doutoramento, Harvard University. Série Antropologia 110, Brasília: DAN, UnB.

PEIRANO, Mariza G. S. 1992. Uma Antropologia no plural: três experiências contemporâneas. Brasília: Editora Universidade de Brasília.

PEIRANO, Mariza. G. S. 1995. "Desterrados e exilados: antropologia no Brasil e na Índia”. In: CARDOSO DE OLIVEIRA, Roberto; RUBEN, Guilherme Raul. (orgs.), Estilos de Antropologia. Campinas, SP: Editora da UNICAMP, p.13-30.

PETERSON, Nicolas. 1990. "Studying man and man's nature": the history of the institutionalisation of Aboriginal anthropology. Australian Aboriginal Studies, (2), p. 3-19.

PETERSON, Nicolas. 2010. “Other people's lives: Secular assimilation, culture and ungovernability”. In: ALTMAN, Jon; HINKSON, Melinda, (orgs.). Culture Crisis: 
Anthropology and Politics in Aboriginal Australia, UNSW Press, Sydney, p. 248-258

PINA CABRAL, João de. 2004, "Uma história de sucesso: a antropologia brasileira vista de longe”. In: TRAJANO FILHO, Wilson; RIBEIRO, Gustavo Lins (orgs.). O Campo da Antropologia no Brasil. Rio de Janeiro: Contra Capa Livraria; Associação Brasileira de Antropologia, p. 249-265.

POVINELLI, Elizabeth A., 1993. Labor's Lot: the power, history, and culture of Aboriginal action. Chicago/Londres: The University of Chicago Press.

POVINELLI, Elizabeth A., 2002. The cunning of recognition: indigenous alterities and the making of Australian multiculturalism. Durham, NC: Duke University Press.

POVINELLI, Elizabeth A., 2010. "Indigenist politics in late liberalism”. In: ALTMAN, Jon; HINKMAN, Melinda, (orgs.). 2010, Culture Crisis: Anthropology and Politics in Aboriginal Australia, UNSW Press, Sydney, p. 17-30.

PRESTON, Richard J. 1983. "The social structure of an unorganized society”: beyond intentions and peripheral Boasians. In: MANNING, F. (ed.), Consciousness and Inquiry: Ethnology and Canadian Realities. National Museum of Man Mercury Series. Ottawa: National Museums of Canada, p. 286-305.

RAMOS, Alcida Rita. 1990. "Ethnology Brazilian Style”. Cultural Anthropology, 5(4), p. $452-457$.

RAMOS, Alcida Rita. 1998. Indigenism: ethnic politics in Brazil. Madison. Madison, Wisconsin: The University of Wisconsin Press.

RAMOS, Alcida Rita. 2010. "Revisitando a etnologia à brasileira”. In: C. B. Martins; L. F. D. Duarte. (orgs.), Horizontes das ciências sociais no Brasil: antropologia. São Paulo: ANPOCS, p. 25-49.

REPETTO, Maxim. 2008. Movimentos Indígenas e Conflitos Territoriais no Estado de Roraima. Boa Vista: Editora da UFRR.

RIBEIRO, Darcy. 1979 [1977]. Os Índios e a Civilização: a integração das populações indígenas no Brasil moderno. $3^{\mathrm{a}}$ edição, Petrópolis: Editora Vozes Ltda.

RIBEIRO, Gustavo Lins. 2006. “Antropologias Mundiais: para um novo cenário global na antropologia”. Revista Brasileira de Ciências Sociais, 21(60), p. 147-185.

RIBEIRO, Gustavo Lins; ESCOBAR, Arturo. (Org.). 2012. Antropologias Mundiais: transformações da disciplina em sistemas de poder. Brasília: Editora UnB.

RIBEIRO, Gustavo Lins; LIMA, Antônio Carlos de Souza. "O campo da antropologia no Brasil”. In: TRAJANO FILHO, W.; RIBEIRO, G. L. (orgs.) 2004. O Campo da Antropologia no Brasil. Rio de Janeiro: Contra Capa Livraria; Associação Brasileira de Antropologia, p. 7-12. 
RITTER, David. 2009. The Native Title Market. Crawley, Western Australia: University of Western Australia Press.

ROCHA, Leandro Mendes; BAINES, Stephen Grant (orgs.) 2008. Fronteiras e Espaços Interculturais: transnacionalidade, etnicidade e identidade em regiões de fronteira. Goiânia: Editora da UFG.

ROWLEY, Charles Dunford. 1972. Outcasts in White Australia. Sydney: Penguin.

RUBEN, Guilherme Raul. 1995. “O ‘tio materno’ e a antropologia quebequense”. In: CARDOSO DE OLIVEIRA, Roberto; RUBEN, Guilherme Raul. (orgs.). Estilos de Antropologia. Campinas, SP: Editora da UNICAMP, p. 121-138.

RYAN, Lyndall. 1996 [1981]. The Aboriginal Tasmanians. Crows Nest, NSW, Austrália: Allen \& Unwin Pty Ltd.

SANTILLI, Paulo. 1994. As fronteiras da República: história e política entre os Macuxi no vale do rio Branco. São Paulo: NHII-USP; FAPESP.

SANTILLI, Paulo. 2001. Pemongon Patá: território Macuxi, rotas de conflito. São Paulo: Editora da UNESP.

SEARLE, John R. 1969. Speech Acts. Cambridge: Cambridge University Press.

SEEGER, Anthony; VIVEIROS DE CASTRO, Eduardo. "Pontos de Vista sobre os Índios Brasileiros: um ensaio bibliográfico”. In: SEEGER, Anthony. (ed.). Os Índios e Nós: estudos sobre sociedades tribais brasileiras. Rio de Janeiro: Campus, 1980.

SHIGERU, Kayano. 1994 [1980]. Our Land was a Forest: an Ainu Memoir. New York: Westview Press.

SIECIECHOWICZ, Krystyna. 1993. The State of Canadian Anthropology: The perspective from the University of Toronto, I Meeting Siena-Toronto, ms.

SIECIECHOWICZ, Krystyna. 1995. Some Reflections on First Nations Nationalism in Quebec. University of Toronto, ms.

SILVERMAN, Marilyn. 1991. "Dispatch I. Amongst 'Our Selves'”: A colonial encounter in Canadian academia. Critique of Anthropology, 11(4), p. 381-400.

SMITH, M. Estellie. 1984. "“Comments' on Handler, R. On sociocultural discontinuity": nationalism and cultural objectification in Quebec. Current Anthropology, 25(1), p. 67-69.

SOUSA, Cássio Noronha Inglez de; LIMA, Antonio Carlos de Souza; ALMEIDA, Fábio Vaz Ribeiro de Almeida; WENTZEL, Sondra. (orgs.) 2007. Povos Indígenas: projetos e desenvolvimento. Rio de Janeiro: ContraCapa Livraria.

STEPHEN, Lynn 1999. "The Construction of Indigenous Suspects: Militarization and the Gendered and Ethnic Dynamics of Human Rights Abuses, Southern Mexico”. 
American Ethnologist, 26(4), p. 822-842.

STOCKING, Jr., George W., 1982. “Afterword: A View from the Center”. Ethnos, 47, p. $172-186$.

SUTTON, Peter. 2009. The Politics of Suffering: Indigenous Australia and the end of the liberal consensus. Carleton, Victoria: Melbourne University Press.

TEÓFILO DA SILVA, Cristhian. 2008. O Quebec e a Etnologia Indígena. Série Ceppac 016, Departamento de Estudos Latino-Americanos - ELA, UnB, Brasília, 2008. 14 p. Disponível em: <http://ela.unb.br/images/stories/media/serie/016_ silva_2008.pdf $>$.Acesso em: 16 set. 2015.

TEÓFILO DA SILVA, Cristhian. 2014. "Da etnicização das teorias aos dilemas de envolvimento com as Primeiras Nações na anthropologie québecoise”. Interfaces Brasil/Canadá. Canoas, 14(2), p. 231-254.

TRAJANO FILHO, Wilson; RIBEIRO, Gustavo Lins (orgs.) 2004. O Campo da Antropologia no Brasil. Rio de Janeiro: ContraCapa Livraria; Associação Brasileira de Antropologia.

TRIGGER, David S. 1992. Whitefella Comin:Aboriginal responses to colonialism in northern Australia. Cambridge: Cambridge University Press.

TROOD, Russell. B. 1990. “Australian Diplomatic Practice: Methods and Theory”. Journal of Asian and African Studies, XXV(1-2) p. 88-113.

VALVERDE, Sebastián. 2013. "Convergencias disciplinares entre Historia y Antropología: la perspectiva 'histórico-regional' y las investigaciones sobre los pueblos indígenas en Norpatagonia Argentina”. Revista Internacional de Ciencias Sociales interdisciplinarias. Madrid, España: Common Ground Publishing, 2(1). Disponivel em: <http:// ies12.cgpublisher.com/proposals/26/index_html>. Acesso em 03 set. 2015.

VALVERDE, Sebastián; STECHER, Gabriel. 2013. "Ruralidad, paradojas y tensiones asociadas a la movilización del pueblo Mapuche en Pulmarí (Neuquén, Argentina)”. Revista Polis, No 34, Revista de la Universidad Bolivariana. Disponivel em: < http:/ / www.redalyc.org/articulo.oa?id=30528135014>. Acesso em 04 set, 2015.

VIVEIROS DE CASTRO, Eduardo. 1996. "Os pronomes cosmológicos e o perspectivismo ameríndio”. Mana 2(2), p. 115-144.

VIVEIROS DE CASTRO, Eduardo. 1999. "Etnologia brasileira”. In: MICELI, S. (org.). O que ler na ciência social brasileira (1970-1995). Antropologia (volume I). São Paulo/Brasília: Editora Sumaré/ANPOCS/CAPES, p. 109-223.

VIVEIROS DE CASTRO, Eduardo. 2011. The Inconstancy of the Indian Soul: The Encounter of Catholics and Cannibals in Sixteenth-Century Brazil. Chicago: Prickly Para- 
digm Press.

WALDRAM, James, 2004. Revenge of the Windigo. Toronto: University of Toronto Press.

WEAVER, Sally M., 1983a. "Australian Aboriginal Policy: Aboriginal Pressure Groups or Government Advisory Bodies?” (Part I) Oceania, 54(1), p. 1-22.

WEAVER, Sally M., 1983b "Australian Aboriginal Policy: Aboriginal Pressure Groups or Government Advisory Bodies?” (Part II) Oceania, 54(20, p. 85-108.

WEAVER, Sally M., 1984. "Struggles of the Nation-State to Define Aboriginal Ethnicity: Canada and Australia”. In: GOLD, Gerald L. (org.), Minorities and Mother Country Imagery. Social and Economic Papers 13, Institute of Social and Economic Research, Newfoundland, p.182-210.

WEAVER, Sally M., 1985. "Political representativity and indigenous minorities in Canada and Australia”. In: DYCK, Noel. (org.) Indigenous Peoples and the Nation-State: 'FourthWorld' Politics in Canada, Australia and Norway. St. John's, Newfoundland: Institute of Social and Economic Research, Memorial University of Newfoundland.

WILD, Rex; ANDERSON, Pat. 2007. Ampe Akelyernemane Meke Mekarle 'Little Children are Sacred': Report of the Northern Territory Board of Inquiry into the Protection of Aboriginal Children from Sexual Abuse. 2 Vols. Darwin: Northern Territory Government. Dept of the Chief Minister.

WILSON, Thomas M.; DONNAN, Hastings (orgs.). 1998. Border Identities: nation and state at international frontiers. Cambridge, UK: Cambridge University Press. 